Universidade de São Paulo

Faculdade de Filosofia, Ciências e Letras de Ribeirão Preto

Departamento de Química

Programa de Pós-Graduação em Química

"Técnicas modernas em espectrometria de massas aplicadas

no isolamento de bioherbicidas produzidos por microrganismos"

\title{
Tânia Petta
}

Orientador: Prof. Dr. Luiz Alberto Beraldo de Moraes

Dissertação apresentada à Faculdade de Filosofia, Ciências e Letras de Ribeirão Preto da Universidade de São Paulo, como parte das exigências para a obtenção do título de Mestre em Ciências, Área: Química.

RIBEIRÃO PRETO-SP 2008 


\section{FICHA CATALOGRÁFICA}

Petta, Tânia

Técnicas modernas em espectrometria de massas aplicadas no isolamento de bioherbicidas produzidos por microrganismos.

Ribeirão Preto, 2008.

99 p.; $30 \mathrm{~cm}$

Dissertação apresentada à Faculdade de Filosofia, Ciências e Letras de Ribeirão Preto da Universidade de São Paulo, como parte das exigências para a obtenção do título de Mestre em Ciências, Área: Química

Orientador: de Moraes, Luiz Alberto Beraldo
1. Bioherbicidas
2. LC-MS
3.Microrganismo

4. Bioensaio 
"Gradasa la vida, quemeha dadbtanto!"

(Violeta Parra) 


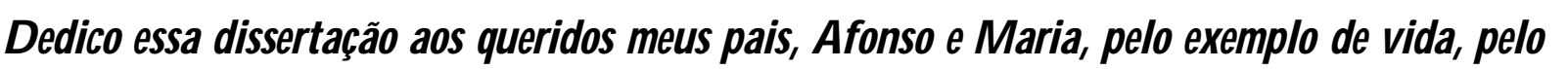
apoia dadicaçãa portodbanur ecainhoeparseremosm dhaes paiscbmundd Acsmasimẽos Adianoelsabłla, pła anizada, comparhiaepda alegia detêlos cono imãos

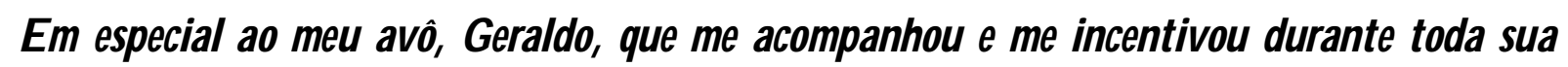
vick!! 


\section{Agadkimentos}

Ao Prof. Dr. Luiz Alberto Beraldo de Moraes, pela orientação, dedicação, competência profissional, confiança, por todas as oportunidades, pelas festas de fim de ano e principalmente pela e amizade durante esses anos.

Ao Prof. Dr. Leonardo Silva Santos, da Universidade de Talca-Chile, pela contribuição para minha formação, pela oportunidade de fazer parte do seu grupo de pesquisa e de conhecer terras chilenas.

A meus queridos companheiros de laboratório e "agregados": Fernanda, Ana Flávia, Cris, Marcelo, Carol, Eduardo, Jussara, André, Tiago (Damãe), Letícia e Simone pelo agradável convívio e pela satisfação de trabal har com vocês todos os dias!

Ao Prof. Dr. Luis Henrique Souza Guimarães (Laboratório de Microbiologia USP-RP), Prof. Dr. Itamar Soares de Melo (Embrapa Meio Ambiente) e a Profa Dra Maria de Lourdes Teixeira de Moraes Polizeli pela grande dedicação com que me ajudou durante a realização desse trabalho,pelas sugestões e ensinamentos de microbiologia.

Ao Prof. Dr. Marcos N. Eberlin (DQ-UNICAMP), Prof. Dr. N orberto Peporine Lopes (FCFRP), Dr. Eduardo Meurer (CORE) e Dr. Fábio Barros (Cebola) (CORE), por possi bilitarem as análises por espectrometria de massas. 
Aos al unos do laboratório de Microbiologia da Embrapa Meio Ambiente, em especial Flávia e Sarah pela ajuda em meus experimentos e pela amizade que construímos.

Aos docentes que participaram da minha banca de Qualificação Prof. Dr. Pietro Ciancaglini e Profa. Dra. Hosana Maria Debonsi Navickiene pelas valiosas sugestões.

Aos funcionários do Departamento de Química da FFCLRP, Lâmia, Émerson, Sônia, Bel e André pelo auxílio e atenção que sempre recebi. À Virgínia, pelos experimentos de RMN e ao Djalma pelas análises de infravermel ho e massas.

Ao CN Pq pela bolsa de estudos concedida e à FA PESP pel o auxílio à pesquisa. Aos meus grandes amigos Lilian, Tati, Bruno, Pito, Paula, Lili, Vagninho, Mel, Flávia, N eto, Fabi, Bruna, Céli, Marlene, Cristine e A mna pelo privilégio de conhecer vocês!! Temos muita história pra contar...

Ao meu namorado To pelo companheirismo, carinho e paciência!!

A todos meus familiares em especial a minha querida prima Flávia.

A minha família chilena Tia Jackeline, Tio Jorge, Jano, Cláudio, Jorgito, Carlita e Seb por terem-me "adotado", por sempre me ajudar e por todos os momentos felizes que me proporcionaram na Ciudad de Talca. M uchas gracias!!

Aos meus pais aos meus queridos irmãos. Sem vocês eu não teria chegado até aqui!! A mo muito vocês!!

E a música, presente em todos os momentos da minha vida!! 


\section{RESUMO}

Neste trabalho foi empregada uma metodologia rápida e eficiente para a identificação de metabólitos fitotóxicos produzidos por microrganismos. O isolamento do composto bioativo foi guiado através de bioensaio com Lemna minor. A espectrometria de massas, em especial o LC-MS, foi utilizada para acelerar o processo identificação do composto ativo.

As bactérias estudadas eram simbióticas do fungo fitopatogênico Sclerotium rolfsii. Seus respectivos extratos orgânicos obtidos de culturas em meio BD (batata dextrose) foram submetidos ao ensaio de fitotoxicidade com Lemna minor. Entre cinco bactérias foi sel ecionada a bactéria Burkholderia sp, a qual apresentou maior atividade no ensaio de fitotoxicidade. O fracionamento por cromatografia em coluna de sílica propiciou a identificação de uma fração ativa. A fitotoxina foi caracterizada como sendo um macropentólido de 20 membros. O composto pertence à classe dos polihidroxibutiratos (PHBs). Sua estrutura foi determinada por RMN ${ }^{1} \mathrm{H}, \mathrm{RMN}{ }^{13} \mathrm{C}$, HMQC, HMBC, IV, ESI-MS/ MS e também por comparação com dados da literatura. Esse composto nunca foi isolado de fontes naturais. Foi descrito na literatura uma rota sintética para sua obtenção, porém esta é a primeira vez que sua atividade fitotóxica é relatada. Este trabal ho mostra uma nova perspectiva para o emprego de PHBs de baixo peso molecular e apresenta uma proposta de estrutura de composto fitotóxico que pode servir de modelo para a síntese de novos herbicidas. 
ABSTRACT

In this work a quick and efficient methodology was employed for the identification of phytotoxic metabolites produced by microorganisms. The isolation of the bioactive compound was guided by Lemna minor bioassay. Mass spectrometry, especially LC-MS, was used to accelerate the process of identification of the phytotoxin.

All bacteria were symbiotic to the phytopatogenic fungi Sclerotium rolfsii.. The bacterium Burkholderia sp was selected among the five bacteria analyzed, due to its greater phytotoxic activity in the bioassay. The phytotoxin was characterized as a 20 member macropentolide. This compound belongs to the polyhidroxybutirates (PHBs) chemical dass. Its structure was determined by NMR내, NMR ${ }^{13} \mathrm{C}, \mathrm{HMQC}$, HMBC, IV, ESI-MS/ MS and HRMS. It has never been isolated from natural sources before. Although a synthetic route has been proposed in the literature this is the first time that its phytotoxic activity is reported. This work leads to a new perspective for the application of low molecular weight PHBs and propose a phytotoxic structure that can be used as a model for the synthesis of new herbicide class. 


\section{Lista de Figuras}

Figura 1. Principais herbicidas sintéticos empregados como pesticidas. 4

Figura 2. Herbicida bialafos produzido por Streptomyces higroscopicus e o derivado sintético glifosato.. 7

Figura 3. A nisomicina, fitotoxina produzida por Streptomyces sp e o herbicida sintético NK-049..........8

Figura 4. Fitotoxina produzida pelo fungo A scochyta caulina............................................................. 8

Figura 5. Fitotoxinas produzidas pelos fitopatógenos Streptomyces scabeis eS. acidiscabies. .................... 9

Figura 6. Metodologia empregada na separação de metabólitos secundários........................................ 11

Figura 7. A nálise de LC-MS/ MS empregada na desreplicação de compostos presentes em extratos de plantas......

Figura 8. Bioensaio de fitotoxicidade empregando Lemna minor ......................................................... 16

Figura 9. Compostos fitotóxicos isolados de folhas de Laggera decurrens guiado por bioensaio com

Lemna minor.

Figura 10. Metodologia empregada para o isolamento de fitotoxinas. ................................................ 19

Figura 11. Síntese de oligômeros cíclicos a partir do ácido (R)-3-hidroxibutírico. ................................. 28

Figura 12. Estrutura da fitotoxina rizoxina produzida pela bactéria endossimbionte Burkhol deria rhizoxina.

Figura 13. Substância rizobitoxina produzida pela bactéria simbionte Bradyrhizobium el kani............... 34

Figura 14. Ensaio de fitotoxicidade das bactérias EMB1B, EMB2B, EMB3B, EMB5B eEMB6B com L. minor, fermentadas por 11 dias em meio BD a 28 C............................................................ 35

Figura 15. Espectros de massas ESI +e potencial do cone 55V dos extratos orgânicos de EM B1B e, EMB2B, EMB3B, EMB5B e EMB6B, fermentados por 5 dias em meio BD............................... 39

Figura 16. Espectros de massas ESI+ e potencial do cone $55 \mathrm{~V}$, dos extratos orgânicos de EMB1B e, EMB2B, EM B3B, EM B5B eEMB6B, fermentados por 11 dias em meio BD ............................ 41

Figura 17. Cromatogramas de LC-UV dos extratos das bactérias EMB obtidos com 11 dias de fermentação. Fase móvel $\mathrm{H}_{2} \mathrm{O} / \mathrm{ACN} 10 \%$, coluna C18 $(4.60 \times 250 \mathrm{~mm})$, modo isocrático e fluxo $1 \mathrm{ml} / \mathrm{min}$ e $\lambda=215 \mathrm{~nm}$.

Figura 18. Sinais que caracterizam a presença de surfactinas no extrato EM B1B.................................44

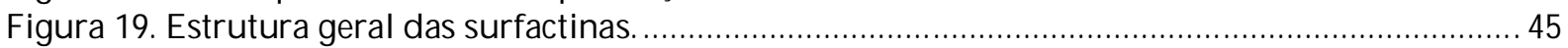

Figura 20. a) Espectro de ESI-MS/ MS do sinal de $\mathrm{m} / \mathrm{z}(\mathrm{M}+\mathrm{H})+1037$, obtido em modo positivo. b)

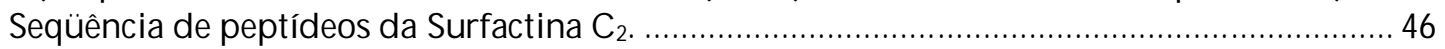

Figura 21. Ensaio de fitotoxicidade da bactéria EMB5B com L. minor, fermentadas por 5, 11, 17 e 21

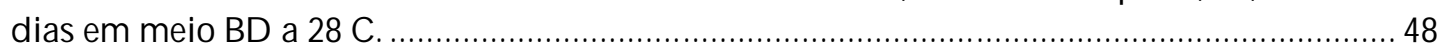

Figura 22. Espectros de massas ESI+ da bactéria EM B5B com 5, 11, 17 e 21 dias de fermentação, a $28^{\circ} \mathrm{C}$

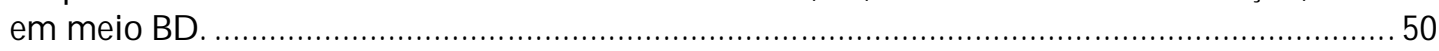

Figura 23. Cromatogramas de LC-UV dos extratos EM B5B obtidos em dias diferentes de fermentação. Fase móvel: $\mathrm{H}_{2} \mathrm{O} / \mathrm{ACN} 10 \%$, coluna C18 $(4.60 \times 250 \mathrm{~mm})$, fluxo $1 \mathrm{ml} / \mathrm{min}$ em $215 \mathrm{~nm}$......... 52

Figura 24. Ensaio de fitotoxicidade das frações cromatográficas F1, F2, F3, F4 eF5 do extrato bactéria EMB5B-15dias com L. minor.

Figura 25. LC-UV da fração ativa, fase móvel $\mathrm{H}_{2} \mathrm{O} / \mathrm{ACN} 10 \%$, modo isocrático e fluxo $1 \mathrm{ml} / \mathrm{min}$.

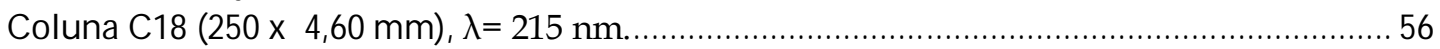

Figura 26. Espectro de massas referente à fração 1 no modo ESI +...................................................... 57

Figura 27. (a) extração do íon m/z 453 e (b) cromatograma de LC-MS do extrato EMB5B-11dias (ESI +, potencial do cone $50 \mathrm{~V}$ ). Fase móvel: $\mathrm{H}_{2} \mathrm{O} / \mathrm{ACN} 10 \%$ eácido fórmico $0,1 \%$, coluna $\mathrm{C} 18$

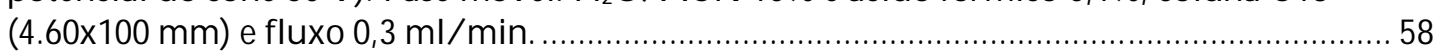

Figura 28. Espectro de ESI-MS/ MS do íon de $/ 2431[\mathrm{M} \mathrm{+H}]^{+}$no modo ESI+, potencial do cone $30 \mathrm{~V}$ e

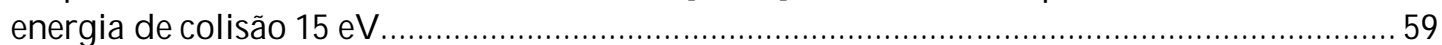

Figura 29. Proposta mecanística para a fragmentação do composto de $\mathrm{m} / \mathrm{z} 431 . . . \ldots \ldots . . . . . . . . . . . . . . . . . . . . . . . . .60$

Figura 30. Espectro deESI-MS/ MS do composto de $\mathrm{m} / \mathrm{z} 453\left[\mathrm{M}+\mathrm{N}\right.$ a] ${ }^{+}$no modo $\mathrm{ESI}+$, potencial do cone $45 \mathrm{~V}$ e energia decolisão $25 \mathrm{eV}$. 
Figura 31. Estrutura do pentâmero fitotóxico 63

Figura 32. Espectro de Infravermel ho da Fração 1.

Figura 33. Espectro de RMN $1 \mathrm{H}$ do composto bioativo da bactéria, obtido em $500 \mathrm{MHZ}$ (CDCl 3 -TMS).

Figura 34. Espectro de RMN $13 C$ do composto bioativo da bactéria EMB5B, obtido em $400 \mathrm{M} \mathrm{Hz}$ ( $\mathrm{CDCl}_{3}$-TMS).

Figura 35. Espectro de HMQC do composto bioativo da bactéria EMB5B, obtido em 400MHz.(CDCl 3 , 68
TMS) 70

Figura 36. Espectro de HMBC do composto bioativo da bactéria EMB5B, obtido em 500M Hz. $\left(\mathrm{CDCl}_{3}\right.$

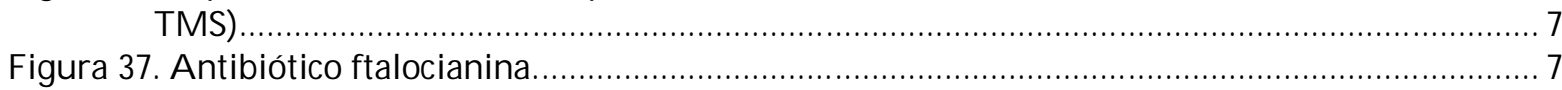

Figura 38. Conformação otimizada (MM2) do pentólido fitotóxico. ......................................................... 74

Figura 39. Macrolactonas fitotóxicas produzidas pelo fungo Cladosporium tenuissium.......................... 75

Figura 40. Macrolactonas produzidas pelo fungo Colletrotrichum gl oeosporioides .................................... 75

Figura 41. Esquema do experimento de MRM (Monitoramento de Reações Múltiplas). .......................... 76

Figura 42. Cromatograma de LC-MS/ MS (modo MRM), canal m/ z 431>155, para a fermentação da bactéria EMB5B para o branco 8, 15 dias (meio BD)............................................................... 78

Figura 43. Monitoramento da produção do composto bioativo na fermentação da bactéria EMB5B em meio $\mathrm{BD}$ a $28^{\circ} \mathrm{C}$

Figura 44. Cromatogramas de LC-UV da fração ativa e dos extratos EMB5B obtidos em meios BD, aveia, TSB e quínua. Fase móvel: $\mathrm{H}_{2} \mathrm{O} / \mathrm{ACN} 10 \%$ e acetato de amônio $10 \mathrm{mM}$, coluna $\mathrm{CN}$ $(4.60 \times 250 \mathrm{~mm})$, fluxo $1 \mathrm{ml} / \mathrm{min}$ e $254 \mathrm{~nm}$. 82

Figura 45. Espectros de massas ESI+ dos extratos orgânicos de EMB5B-5dias. Potencial do cone 55eV.

Figura 46. Espectro de massas ESI + do bruto reacional da síntese do pentólido. ................................... 88

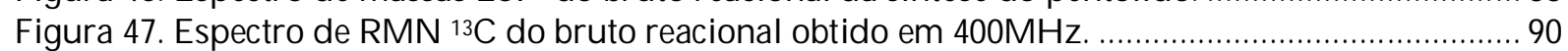




\section{Lista de Tabelas}

Tabela 1. Substâncias produzidas por microrganismos .....................................................................

Tabela 2. Fitotoxinas promissoras para o uso como herbicidas............................................................. 5

Tabela 3. Composição do meio de cultura SIS para Lemna minor. .......................................................... 25

Tabela 4. Identificação preliminar das bactérias pelo método FAME.................................................... 30

Tabela 5. Diversidade de organismos submetidos ao bioensaio de fitotoxicidade com Lemna minor .... 33

Tabela 6. Resultado dos testes de fitotoxicidade dos extratos orgânicos das bactérias EMB................. 35

Tabela 7. Fracionamento do extrato EM B5B e bioensaio de fitotoxicidade.......................................... 54 


\section{Lista de Abreviaturas e siglas}

ACN - A cetonitrila

BD - Batata-Dextrose

CCD - Cromatografia em Camada Delgada

H PLC - Cromatografia Líquida de Alta Eficiência

(do inglês High Performance Liquid Chromatography)

Da - Unidade de massa atômica Dalton. (1Da=1 u.m.a)

DAD - Detector de A rranjo de Diodos

ESI-MS - Espectrometria de Massas com Fonte de Ionizaçao Electrospray

(do inglês Electrospray Ionization Mass Spectrometry)

ESI-M S/M S - Espectrometria de Massas Seqüencial com Fonte de lonização por Electrospray （do inglês Tandem Electrospay Ionization Mass Spectrometry)

EtOAc - Acetato de Etila

FAM E - Ésteres Metílicos deÁcidos Graxos

(do inglês Fatty Acid Methyl Ester)

H M Q C - Correlação Heteronuclear de Quantum Múltiplo

(do inglês Heteronuclear Multiple Quantum Correlation)

H M BC - Correlação Heteronuclear de Ligações Múltiplas

(do inglês Heteronuclear Multiple Bond Correlation)

J - Constante de Acoplamento

LC-M S-Cromatografia Líquida acoplada a Espectrometria de Massas

(do inglês Liquid Chromatography - Mass Spectrometry)

LC-M S/M S-Cromatografia Líquida A coplada a Espectrometria de M assas Seqüencial

(do inglês Liquid Chromatography - Tandem Mass spectrometry)

LC/UV - Cromatografia Líquida com detector de UItra-Violeta

((do inglês Liquid Chromatography - Ultra Violet Spectroscopy))

m/z - Razão M assa-Carga

M RM - Monitoramento de Reações Múltiplas

(do inglês Multiple Reaction Monitoring)

PCR - Reação em Cadeia da Polimerase (do inglês Polimerase Chain Reaction)

PHA - Polihidroxialcanoato

PH B - polihidroxibutirato

RM N - Ressonância Magnética Nuclear 
$\mathbf{t}_{\mathbf{R}}$ - Tempo de Retenção

TSB - Caldo tripticaseína e soja (do inglês Tryptic Soy Broth)

TSBA - Caldo tripticaseína, soja e ágar (do inglês Tryptic Soy Broth Á gar) 
Índice

1- INTRODUÇÃO ..................................................................................................................1

1.1 - METABÓLITOS SECUNDÁRIOS BIOATIVOS PRODUZIDOS POR MICRORGANISMOS.......... 1

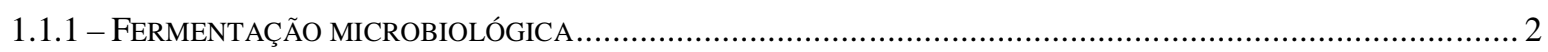

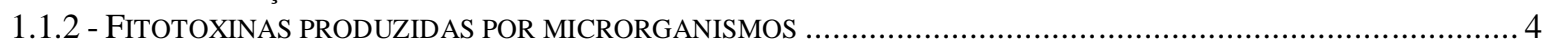

1.2- ESPECTROMETRIA DE MASSAS ACELERANDO A IDENTIFICAÇÃO DE FITOTOXINAS.... 10

1.3 - BIOENSAIOS COMO GUIA NO ISOLAMENTO DE FITOTOXINAS .......................................... 14

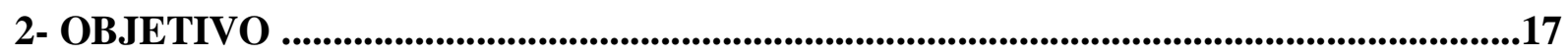

3. MATERIAIS E MÉTODOS.......................................................................................................18

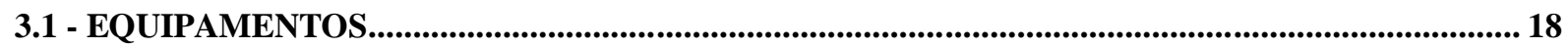

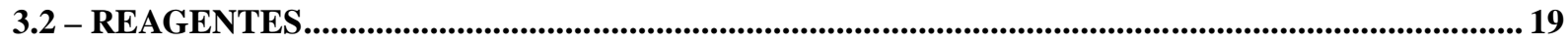

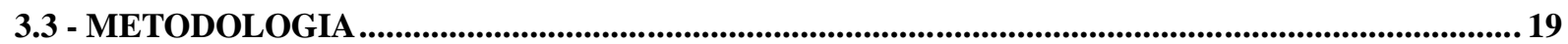

3.4 - ISOLAMENTO DAS BACTÉRIAS E MANUTENÇÃO DAS CEPAS.................................................. 20

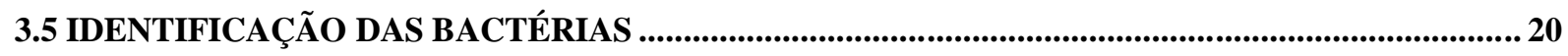

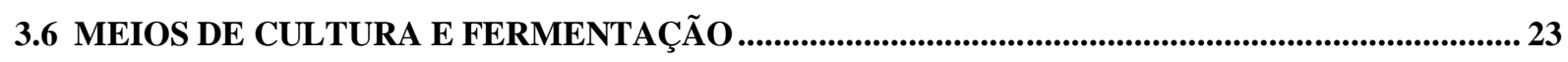

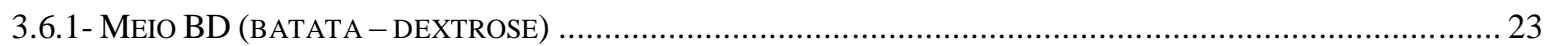

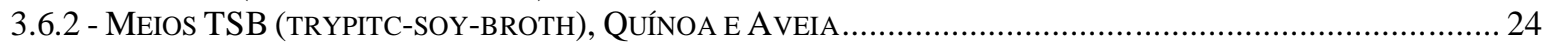

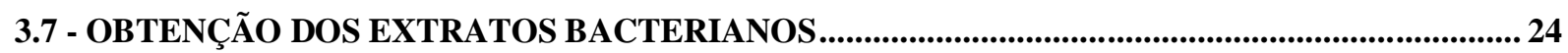

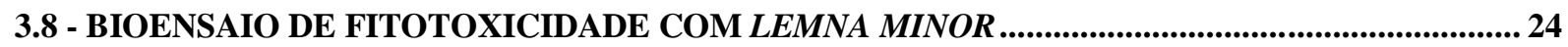

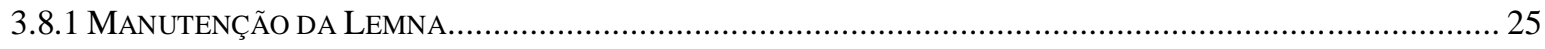

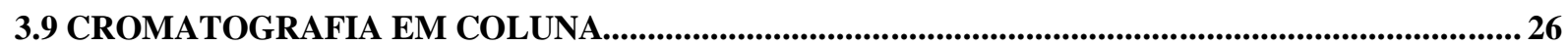

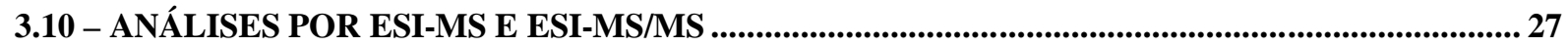

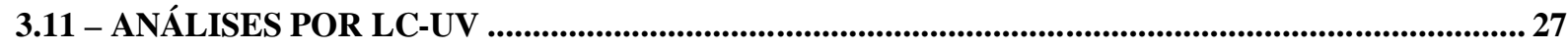

3.12 - SÍNTESE DO COMPOSTO BIOATIVO E HOMÓLOGOS................................................................. 27

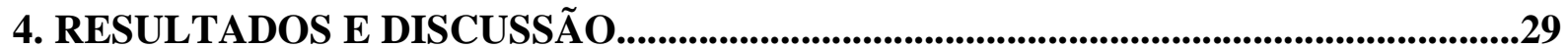

4.1 - ISOLAMENTO E IDENTIFICAÇÃO DOS MICRORGANISMOS ................................................. 29

4.2 - SCREENING BIOLÓGICO DOS EXTRATOS BRUTOS EMPREGANDO LEMNA MINOR......... 32

4.3- COMPARAÇÃO ENTRE OS PERFIS QUÍMICOS DOS EXTRATOS.............................................. 36

4.4 - EFEITO DO TEMPO DE CULTIVO NA PRODUÇÃO DE FITOTOXINAS..................................... 47

4.5 - FRACIONAMENTO DO EXTRATO BRUTO EMB5B E IDENTIFICAÇÃO DO PRINCÍPIO

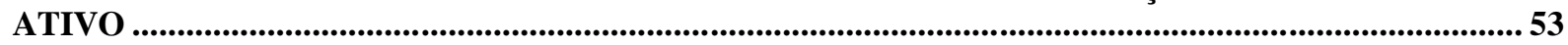

4.6 - MONITORAMENTO DA PRODUÇÃO DO COMPOSTO ATIVO POR MRM............................... 75

4.7 - INFLUÊNCIA DO MEIO DE FERMENTAÇÃO...................................................................................... 80

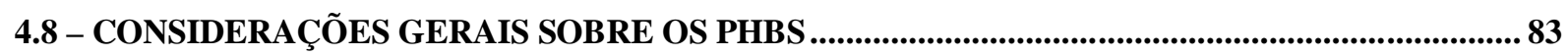


4.9 - DESREPLICAÇÃO DO EXTRATO BRUTO DA EMB5B .................................................................. 84

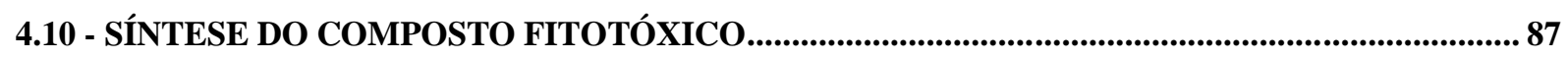

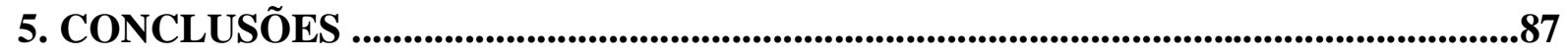

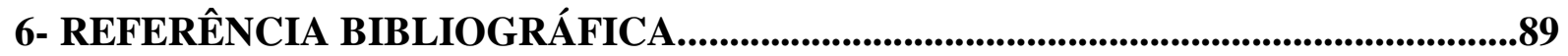




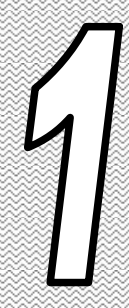

\section{Introduçäa}

\section{1 - Metabólitos secundários bioativos produzidos por microrganismos}

A natureza produz uma enorme variedade de metabólitos secundários das mais variadas classes. Cerca de 100.000 substâncias produzidas por plantas e microrganismos, que possuem alguma atividade biológica, já foram caracterizadas. ${ }^{1}$ Estima-se que 77,8\% dos fármacos anticancerígenos aprovados entre 1981 e 2006, são produtos naturais ou derivados de produtos naturais. $^{2}$

Sabe-se que microrganismos como bactérias e fungos, além de serem responsáveis por importantes transformações metabólicas, pelo controle biológico de doenças e pragas, pela degradação de resíduos vegetais e outros produtos, são também poderosos mananciais na produção de metabólitos secundários das mais variadas classes. O exemplo mais conhecido da aplicação terapêutica desses metabólitos secundários são os antibióticos. ${ }^{3}$ 
Tabela 1. Substâncias produzidas por microrganismos

\begin{tabular}{lll}
\hline Composto/Classe & Propriedades & \multicolumn{1}{c}{ Microrganismo } \\
\hline Avermectina & Antelmíntico & Streptomyces avermitilis \\
Cefalosporina C & Antibiótico & Cephalosporium acremonium \\
Bacteriocinas & Biopreservativos & Lactobacillus lactis \\
Carotenóides & Pigmentos & Dunaliella bardarwil (alga) \\
Elastatinal & Inibidor de Elastase & Vários Streptomyces \\
Giberelinas & Hormônios de Plantas & Gibberella fujikuroi \\
Herbecidina & Herbicida & Streptomyces saganonensis \\
Fosfatidil & Surfactante & Rhodococcus sp. \\
Piericidina & Inseticida & Streptomyces mobaraensis \\
Vitamina $\mathrm{B}_{12}$ & Vitamina & Pseudomonas sp. \\
$($ Cobalamina) & & \\
\hline
\end{tabular}

Além de antibióticos, microrganismos sintetizam substâncias que possuem atividades biológicas diversas tais como hormônios, toxinas, agentes anticancerígenos e agentes inseticidas (Tabela 1). ${ }^{4}$

As estruturas químicas dos metabólitos secundários são bastante complexas e diversificadas, variando entre si de espécie para espécie ou até mesmo dentre as mesmas cepas isoladas de ambientes diferentes. ${ }^{5}$

\subsection{1 - Fermentação microbiológica}

A versatilidade da biossíntese microbiana é enorme. Metabólitos secundários produzidos por microrganismos podem ser obtidos em grandes quantidades por processos fermentativos, uma vez que há possibilidade do controle sobre as 
condições dos meios de cultivo para produção desses metabólitos. Os microrganismos possuem algumas características importantes que justificam sua grande aplicação biotecnológica, dentre elas: facilidade de adaptação em diversos ambientes, o que permite transpor um microrganismo da natureza para o laboratório e posteriormente cultivá-lo em escala industrial; possuem um rápido mecanismo de nutrição e altas taxas de metabolismo e biossíntese; podem realizar uma grande variedade de reações; possibilidade de manipulação genética e capacidade de biossíntese de enantiômeros específicos, geralmente ativos, o que dificilmente ocorre na química sintética.6,7

Os microrganismos usual mente degradam moléculas de alto peso molecular e as convertem em suas subunidades como aminoácidos, nucleotídeos, vitaminas, carboidratos e ácidos graxos, as quais são precursores de proteínas, coenzimas, ácidos nucléicos, peptídeos, polissacarídeos e lipídeos, usados para o seu crescimento e sobrevivência.

Como outros organismos, eles atuam com extraordinária economia de material e energia, evitando a superprodução de metabólitos de forma a poderem sobreviver e competir no ambiente. Para isso eles possuem mecanismos de controle envolvendo a indução de substrato, regulação por realimentação e regulação nutricional, entre outras.

A modificação destes mecanismos é desejável quando se quer uma superprodução de um metabólito secundário específico, sendo esta a essência dos processos de fermentação. Variações das condições ambientais induzem os 
microrganismos a responderem a estes estímulos produzindo metabólitos, proteínas, toxinas, que os tornem adaptáveis às novas condições.7

\subsection{2 - Fitotoxinas produzidas por microrganismos}

Aproximadamente 30.000 variedades de ervas daninhas estão distribuídas pelo planeta. A perda líquida da produção de grãos, causada por 1.800 tipos dessas plantas, somam $9.7 \%$ da produção agrícola total a cada ano. ${ }^{8}$ Ervas daninhas são plantas que crescem em locais indesejáveis e competem com a plantação por nutrientes e disseminam suas sementes, o que faz perpetuar o problema para as gerações seguintes. $^{9}$

Atualmente os herbicidas sintéticos são os pesticidas mais usados para o extermínio dessas pragas agrícolas. ${ }^{3}$ Dentre os mais conhecidos estão o 2,4D; MCPA, diuron ea atrazina (Figural). ${ }^{10}$<smiles>O=C(O)COc1ccc(Cl)cc1Cl</smiles>

$2,4-D$<smiles>Cc1cc(Cl)ccc1OCC(=O)O</smiles>

MCPA<smiles>CCNc1nc(Cl)nc(NC(C)C)n1</smiles>

Atrazina<smiles>CN(C)OCNc1ccc(Cl)c(Cl)c1</smiles>

Diuron

Figura 1. Principais herbicidas sintéticos empregados como pesticidas.

Certamente, esses agroquímicos têm sido eficientes no controle de pestes agrícolas. No entanto, são bastante conhecidos os problemas resultantes do seu uso 
constante e, muitas vezes, indiscriminado. Dentre eles os principais são os efeitos danosos causados ao meio ambiente, afetando os seres vivos, causando desequilíbrios biológicos e aumentando resistência das espécies alvo, tornado o tratamento, em muitas vezes, ineficaz e de alto custo. ${ }^{11}$

Muitas fitotoxinas produzidas tanto por plantas como por microrganismos possuem potencialidade para serem empregadas como herbicidas, ou melhor, como bioherbicidas. Como exemplos de fitotoxinas de origem vegetal, têm-se os aleloquímicos, compostos que regulam o crescimento de outros vegetais. ${ }^{12,13}$ Entretanto, a evolução das plantas para a produção de fitotoxinas potentes, pode acarretar em auto-toxicidade para as mesmas. Por isso, os microrganismos são fontes mais promissoras de bioherbicidas. ${ }^{14}$

A Tabela 2 apresenta algumas fitotoxinas promissoras para o uso como bioherbicidas, bem como os modos de ação e a fonte microbiana. 4

Tabela 2. Fitotoxinas promissoras para o uso como herbicidas

\begin{tabular}{lccc}
\hline Fonte microbiana & Fitotoxina & Ervas daninhas & Modo de ação \\
\hline \multicolumn{1}{c}{ Fungos } & Tentoxina & Gramas & CF 1-ATPase \\
\hline Alternaria alternata & Ascochitina & Sida espinhosa & $\begin{array}{c}\text { Inibição do } \\
\text { crescimento da raiz e } \\
\text { perda de eletrólitos }\end{array}$ \\
\hline Fuscochyta hyalospora & Ácido & Amplo espectro de ervas & daninhas \\
fusárico & $\begin{array}{c}\text { Peroxidação de } \\
\text { lipídeos e ação } \\
\text { fotosensibilizante }\end{array}$ \\
\hline $\begin{array}{c}\text { Paecilomyces variotti } \\
\text { SANK 21086 }\end{array}$ & Cornexistina & $\begin{array}{c}\text { Dicotiledôneas e algumas } \\
\text { Monocotiledôneas }\end{array}$ & $\begin{array}{c}\text { Inibição do Aspartato } \\
\text { Amino Transferase } \\
\text { (AST) }\end{array}$ \\
\hline Actinomicetos & & & Agrião de jardim \\
\hline Streptomyces & Polietrina A & Inibe a Ceramida \\
\hline
\end{tabular}


Continuação Tabela 2

\begin{tabular}{lccc}
\hline hygroscopicus & & Sintase \\
\hline Streptomyces sp. & Anisomicina & Grama de curral & $\begin{array}{c}\text { Inibição da } \\
\text { fotossíntese }\end{array}$ \\
\hline Streptomyces sp. A7847 & Herboxidieno & $\begin{array}{c}\text { Amplo espectro de ervas } \\
\text { daninhas }\end{array}$ & Desconhecido \\
\hline $\begin{array}{l}\text { Streptomyces sp. 620061 } \\
\text { Bactérias }\end{array}$ & Pirizadocidina & Rabo de raposa & $\begin{array}{c}\text { Inibição do transporte } \\
\text { de elétrons }\end{array}$ \\
\hline $\begin{array}{l}\text { Streptomyces sp. AM- } \\
\text { B72 }\end{array}$ & Herbimicina & Digitaria spp., Rabo de raposa & Desconhecido \\
\hline $\begin{array}{l}\text { Pseudomonas syringae } \\
\text { var. tabaci }\end{array}$ & Tabtoxina & Amplo espectro de ervas \\
daninhas & Caminho GS-GOGAT \\
\hline $\begin{array}{l}\text { Pseudomonas syringae } \\
\text { var. phaseolicola }\end{array}$ & Faseolotoxina & $\begin{array}{c}\text { Glycine wightii e Macrophillium } \\
\text { atropurpureum }\end{array}$ & $\begin{array}{c}\text { Inibição da Ornitina } \\
\text { Carbamoil }\end{array}$ \\
\hline
\end{tabular}

O emprego de herbicidas produzidos por microrganismos apresenta a vantagem em relação aos herbicidas sintéticos, de serem biodegradáveis, uma vez que o tempo de meia vida é relativamente curto, e portanto não deixam resíduos tóxicos no meio ambiente. São ativos em pequenas quantidades, se comparados às enormes quantidades de pesticidas usados atual mente.

A maioria das fitotoxinas naturais possuem estruturas não-halogenadas, o que os torna menos tóxicas ao ambiente em relação a algumas classes de herbicidas sintéticos. ${ }^{4}$ Pode-se então afirmar que a contaminação de alimentos, do solo e da água é menos provável de ocorrer com os herbicidas naturais. ${ }^{10}$

De acordo com Duke e colaboradores, ${ }^{15}$ as fitotoxinas de origem microbiana podem ser produzidas por microrganismos fitopatogênicos, bem como por aqueles que não apresentam nenhum tipo de virulência.

Microrganismos patógenos de plantas produzem uma variedade de toxinas potentes e muitas vezes específicas e com diferentes modos de ação. Os fitopatógenos 
são mi crorganismos que sintetizam substâncias capazes de provocar doenças, causar lesões, inibir o crescimento de plantas e levar a morte do hospedeiro. ${ }^{16}$

N este contexto, muitos microrganismos não patogênicos produzem fitotoxinas extremamente potentes. Grande parte dos estudos com esses organismos tem sido feitos com microrganismos de solo, principalmente actinomicetos. Porém, outros microrganismos também apresentam potencial para a produção de fitotoxinas como os saprófitos e cianobactérias. 15

As fitotoxinas de origem microbiana que tiveram maior sucesso como herbicidas, foram produzidas por microrganismos não fitopatogênicos. Os herbicidas comerciais gl ifosato e o bialafos foram isolados de actinomicetos do solo. O bialafos é um tripeptídeo, produto de fermentação de Streptomyces higrocopicus, que sofreu modificações estruturais e é atualmente comercializado como glifosato (Figura 2), o componente principal do herbicida Roundup ${ }^{\circledR}$, o herbicida mais vendido no mundo. É facilmente degradado por microrganismos do solo. Este foi o primeiro produto de fermentação que serviu de modelo para a produção de um herbicida comercial . ${ }^{6}$<smiles>[R]OC(=O)C(C)NC(=O)C(C)NC(=O)C(N)CCP(C)(=O)O</smiles>

Bialafos<smiles>O=C(O)CNCP(=O)(O)O</smiles>

Glifosato

Figura 2. Herbicida bialafos produzido por Streptomyces higroscopicus e o derivado sintético glifosato. 
Outro exemplo é a anisomicina, um composto isolado de Streptomyces sp., que possui atividade fitotóxica , porém não chegou a ser empregado diretamente como bioherbicida. Entretanto, alterações sintéticas resultaram no herbicida NK-049, (3,3'dimetil-4-metoxibenzofenona), o qual é comercializado e amplamente utilizado em plantações de arroz (Figura 3). ${ }^{4}$

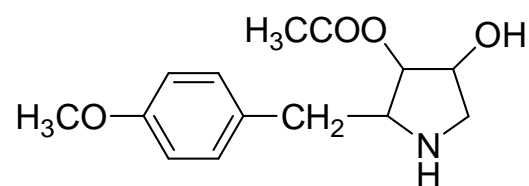

Anisomicina

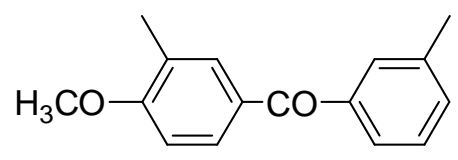

NK-049

Figura 3. Anisomicina, fitotoxina produzida por Streptomyces sp e o herbicida sintético NK049.

A scochyta caulina é um fungo com especificidade para o controle da erva daninha Chenopodium albu. A substância responsável pela fitotoxicidade do fungo foi identificada como ascaulitoxina (Figura 4). Experimentos de campo mostraram que a aplicação direta desta toxina aumentou o controle das pragas em relação ao uso do microrganismo como agente biológico. 16<smiles>N[C@@H](C[C@H](N)C(=O)O)C[C@H](O)[C@@H](N)C[C@H](N)C(=O)O</smiles>

Figura 4. Fitotoxina produzida pelo fungo Ascochyta caulina. 
Importantes fitotoxinas consideradas como promissores herbicidas são as taxtominas (Figura 5), produzidos por Streptomyces scabeis e Streptomyces acidiscabies, os agentes causadores de lesões em batata. ${ }^{9}$

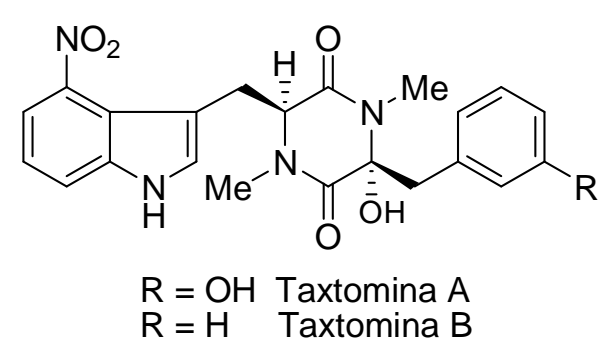

Figura 5. Fitotoxinas produzidas pelos fitopatógenos Streptomyces scabeis e S. acidiscabies.

As bactérias são igualmente responsáveis por uma grande variedade de doenças tanto em plantações quanto em ervas daninhas. A procura por fitotoxinas bacterianas começou principalmente devido à descoberta da toxina tabotoxina, produto do metabolismo secundário da bactéria Pseudomonas syringae var tabaci, que causa doença no tabaco. O modo de ação desse composto é a ini bição da atividade da enzima glutamina sintetase. ${ }^{17}$

É importante ressaltar que o emprego de fitotoxinas isoladas dos microrganismos possui muitas vantagens em relação ao uso de agentes de biocontrole vivos. Geralmente, a logística de estocagem, aplicação, formulação e tempo de meia-vida, favorecem as toxinas sobre os microrganismos. Também a possibilidade de disseminação de alguma doença para espécies não-alvo é menor no caso das toxinas. Além do mais, os fatores ambientais têm muito mais influência sobre a eficácia de um organismo vivo do que sobre suas toxinas. Em vista desses 
fatores, as fitotoxinas de origem microbianas são usadas como modelos para o desenvolvimento de novos herbicidas. ${ }^{18}$

O desenvolvimento do uso de metabólitos secundários de microrganismos, para que possam ser explorados como herbicidas naturais, é um caminho a prevenir o planeta e a humanidade de conseqüências indesejáveis do uso irracional de pesticidas sintéticos. Portanto, espera-se que o uso de herbicidas naturais cresça em uma grandeza de $20 \%$ por ano.19

\section{2 - Espectrometria de Massas acelerando a identificação de fitotoxinas}

O auge dos produtos naturais ocorreu entre as décadas de 1950 e 1970. Durante este período, vários métodos foram desenvolvidos para o isolamento de uma grande variedade de metabólitos secundários. ${ }^{20}$ Entretanto, era despendido muito tempo no isolamento e purificação de novos compostos a partir de produtos naturais, e além disso, o processo apresentava alto custo. ${ }^{21}$

Nos últimos 40 anos, métodos cromatográficos e espectrométricos têm sido empregados no estudo da composição química de uma grande variedade de compostos oriundos de fontes naturais. ${ }^{22}$

Novas metodologias na área de produtos naturais às quais são aplicadas na aceleração do isolamento de substâncias bioativas têm despertado a atenção das indústrias farmacêuticas. Estas metodologias empregam novos métodos para determinação de sua atividade biológica, os quais correlacionam ocorrência, 
atividade, estrutura e pureza, contribuindo significativamente para um grande avanço das técnicas de separação e detecção, com objetivo de possibilitar a rápida caracterização de componentes bioativos presentes em misturas complexas.23

Avanços na tecnologia de instrumentação analítica possibilitaram o acoplamento de métodos de separação e de detecção. Técnicas hifenadas como a cromatografia líquida - espectrometria de massas (LC-MS) e cromatografia líquida ressonância magnética nuclear (LC-NMR) possui grandes vantagens em relação aos procedimentos tradicionais de isolamento e identificação de compostos bioativos, os quais são geralmente laboriosos, demorados e requerem grande quantidades de amostras (Figura 6).

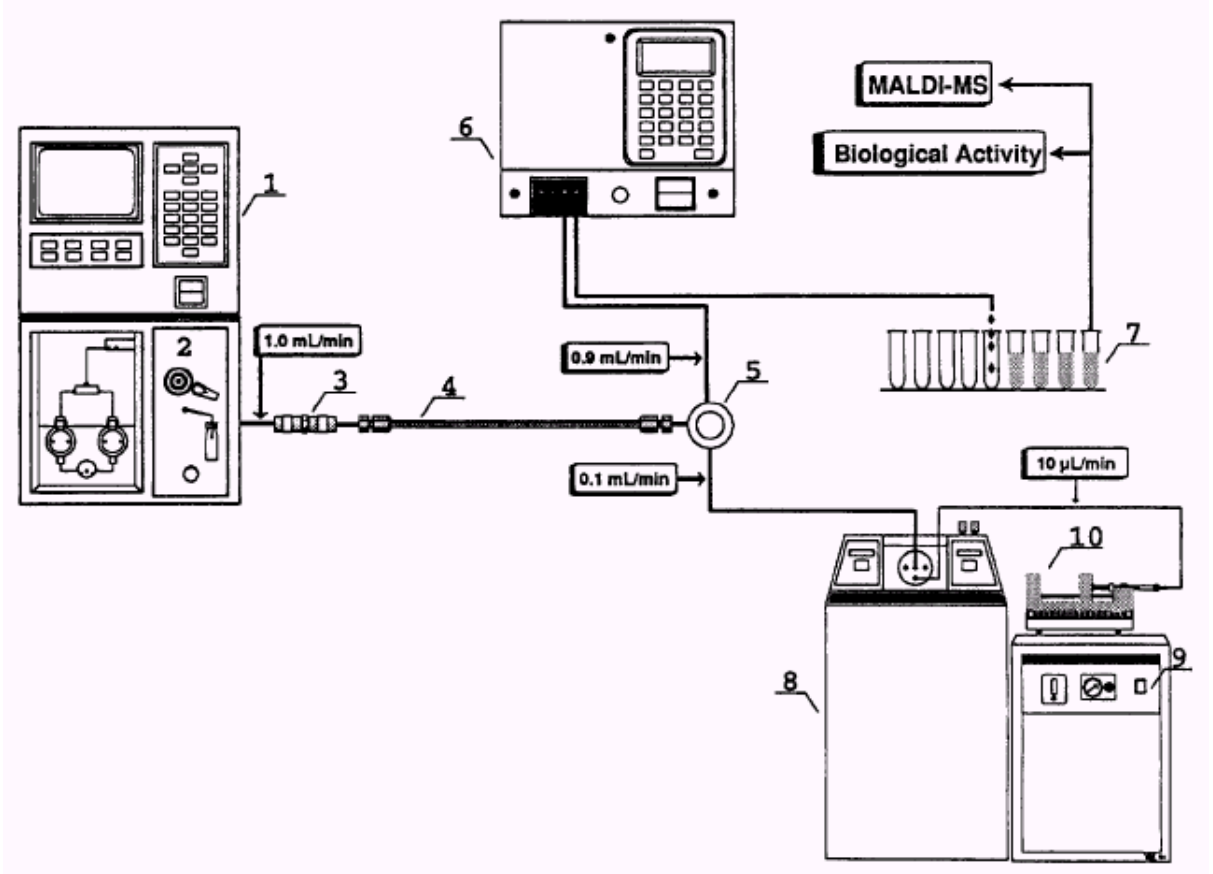

Figura 6. Metodologia empregada na separação de metabólitos secundários. ${ }^{24}$ 
O desenvolvimento da interface entre a cromatografia liquida de al ta eficiência (HPLC) e a espectrometria de massas com a ionização química por pressão atmosférica (API), em especial a fonte de ionização à electrospray (ESI), tornou possível a análise de compostos não voláteis e termolábeis, presentes em matrizes biológicas complexas e a identificação da massa molecular dos compostos presentes na amostra. O sistema LC-MS/ MS é uma combinação poderosa em que é possível obter o padrão de fragmentação característico de um composto e obter informação sobre sua estrutura química. ${ }^{25}$

Atualmente a desreplicação de produtos naturais é acelerada empregando cromatografia líquida de alta eficiência (HPLC) acoplada com espectroscopia de UV e espectrometria de massas (MS). ${ }^{26}$ Técnicas de anál ises como LC-UV, LC/ MS on-line e LC/ RMN off-line (Figura 7), têm revolucionado o processo de purificação de compostos proveniente de fontes naturais. ${ }^{27}$

O sucesso da implementação do "hight throughput screening" (HTS) na identificação de compostos bioativos depende de técnicas que permitem eficiência na desreplicação dos $\operatorname{compostos.~}^{28}$ A desreplicação é a metodologia empregada na identificação e diferenciação de compostos ou classe de compostos ativos, que já tenham sido descritos na literatura contendo atividade idêntica ou similar àquela observada no extrato de interesse. Envolve uma rápida caracterização através de bibliotecas e bancos de dados, em termos de suas massas moleculares em se tratando da espectrometria de massas. ${ }^{29}$ 


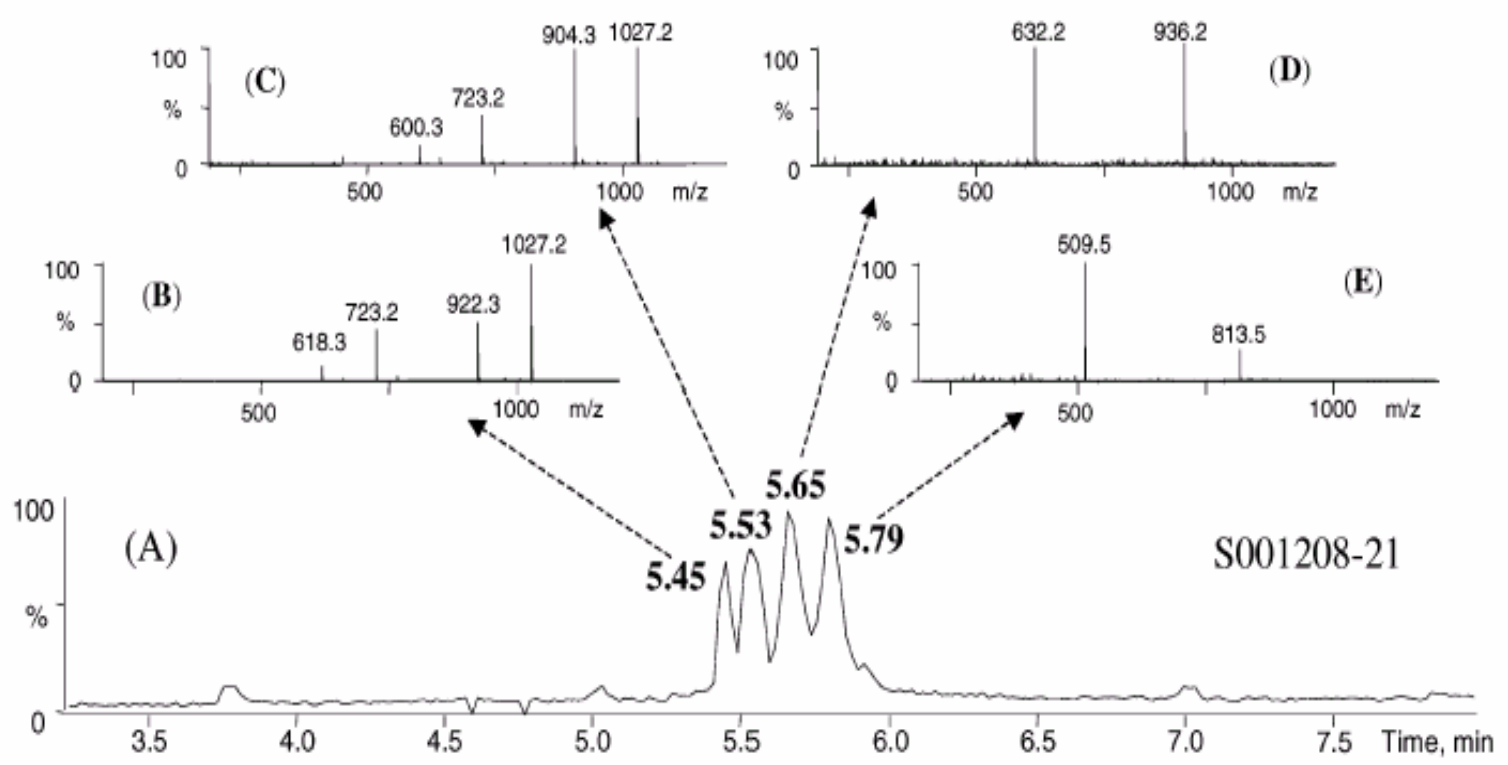

Figura 7. Análise de LC-MS/MS empregada na desreplicação de compostos presentes em extratos de plantas. ${ }^{30}$

Adicionalmente, o processo de desreplicação permite obter uma gama de informações relacionadas ao composto identificado, como bioatividades, fontes alternativas e aplicações. Ayer e colaboradores reportaram que $72 \%$ dos compostos bioativos isolados eram compostos já conheci dos. ${ }^{31}$ Neste contexto, a espectrometria de massas e especialmente a espectrometria de massas de alta resolução é uma tecnologia apropriada para a desreplicação de extratos, usada em combinação com banco de dados de produtos naturais. ${ }^{32}$

O processo de desreplicação também é importante para priorizar o isolamento de compostos ativos inéditos e para agrupar amostras que contêm perfis químicos semelhantes. ${ }^{33}$

Wolfender e colaboradores, ${ }^{34}$ relataram o uso de técnicas acopladas na investigação de metabólitos de plantas. Segundo os autores, a desreplicação dos 
extratos empregando LC-MS, evita o isolamento de compostos de pouco interesse e permitem o isolamento de novos compostos bioativos.

\section{3 - Bioensaios como guia no isolamento de fitotoxinas}

No passado, o foco principal dos pesquisadores de produtos naturais era a elucidação estrutural de uma grande quantidade de novos compostos. A atividade biológica do composto puro era o estágio final do estudo, e pouca atenção era dada a significância do bioensaio no processo de fracionamento dos extratos.

Através de ensaios biológicos é possível avaliar a potencialidade da amostra testada, mesmo antes de se obter qual quer informação sobre a sua composição. Isso é muito importante, principalmente quando se procura atividade biológica em matrizes complexas, como extratos brutos de fermentação de microrganismos.

Para acelerar o processo de identificação de compostos bioativos, os bioensaios iniciais devem ser rápidos, eficientes e de baixo custo. Devem ser sensíveis, altamente reprodutíveis e de fácil interpretação. 35

A procura por novos herbicidas requer ensai os que permitam avaliar os efeitos fitotóxicos das amostras testadas. Uma grande variedade de plantas pode ser usada nesses bioensaios. Um bioensaio bastante empregado para a detecção de fitotoxinas é o ensaio com sementes de alface (Lactuca sativa) e a gramínea A grostis stolonifera L. Para avaliar potencial de fitotoxicidade dos extratos, nesses ensaios considera-se a morfologia das sementes como o crescimento das raízes e do caule e tamanho das 
pétalas. $^{36}$

Outro bioensaio interessante é realizado com raízes de cebola (Alliun cepa), onde é avaliada a inibição da divisão celular. Nesse ensaio, as etapas da mitose das células das raízes da cebola são observadas por um microscópio, com o objetivo de se detectar alguma anormalidade na divisão mitótica dessas células ou uma formação atípica da parede celular, provocado pela fitotoxina em estudo.37

Atualmente o bioensaio mais utilizado emprega espécies de pequenas plantas aquáticas, em especial Lemna minor. Este tem sido empregado na detecção de bioherbicidas e na avaliação da toxicidade de herbicidas sintéticos. ${ }^{38}$ Lemna minor é uma espécie de plantas flutuantes pertencentes à família Leminaceae, presentes em vários ambientes aquáticos, como lagos, rios, efluentes e sedimentos. As plantas são coloniais e formam agregados de duas ou mais pétalas, sendo estas pequenas e de crescimento rápido. É empregada para teste de toxicidade em água devido à sensibilidade a uma grande variedade de substancias orgânicas tóxicas.

Este bioensaio tem a vantagem de avaliar o poder de estimulação de crescimento das substâncias em análise, e de identificar de maneira rápida extratos fitotóxicos. É sensível empregando pequenas quantias de amostra. ${ }^{39}$ Os testes com L.minor são freqüentemente usados por agências reguladoras federais, por industrias e por laboratórios. ${ }^{40}$

A metodologia do bioensaio consiste no crescimento de duas folhas agregadas de L. minor em um meio inorgânico adequado. A pós um período de 7 dias é avaliado o potencial fitotóxico do extrato contra um branco constituído apenas pelo meio 
inorgânico, através da multiplicação das pétalas deL. minor (Figura 8).
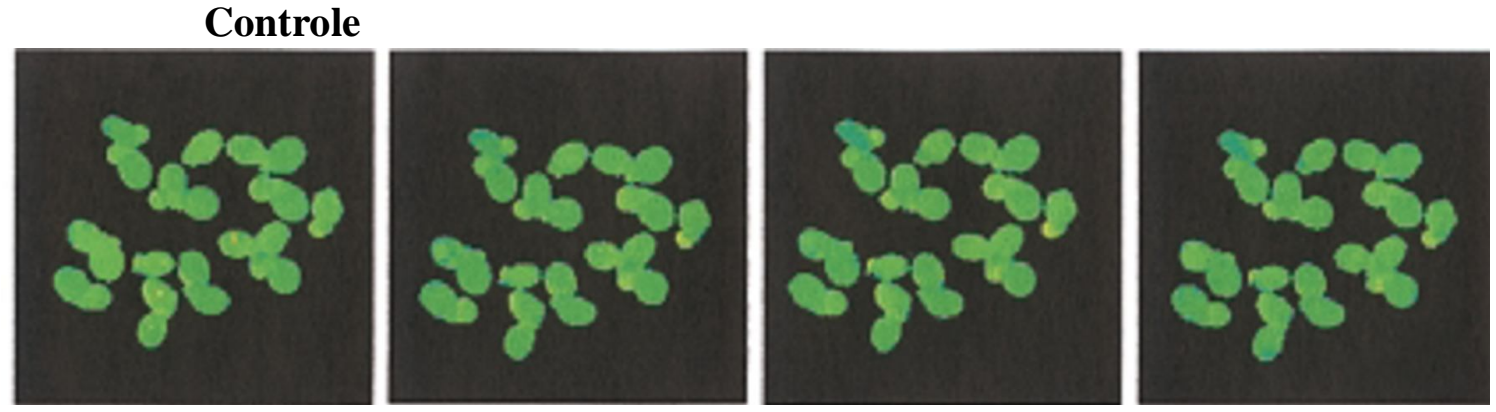

Extrato Bruto
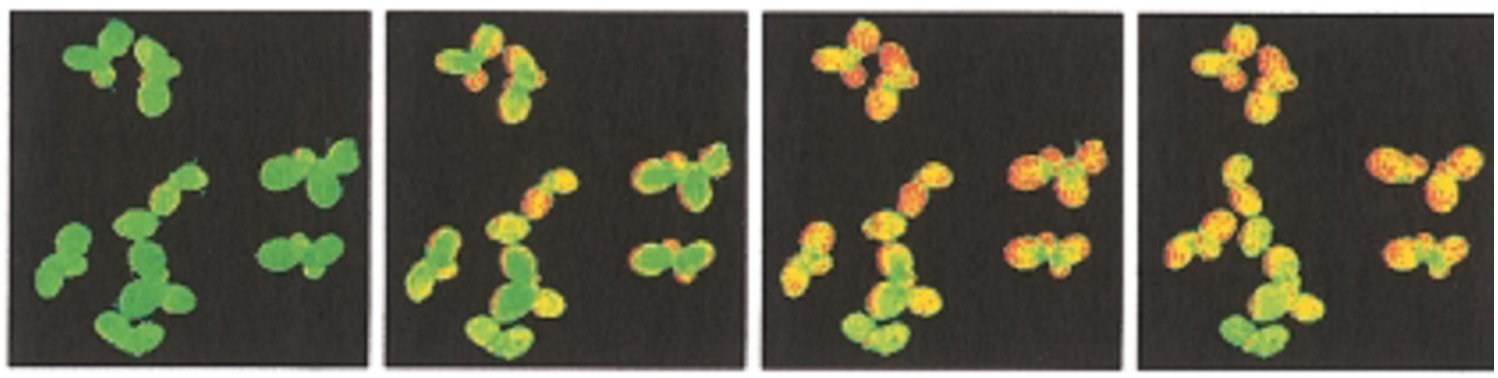

Figura 8. Bioensaio de fitotoxicidade empregando Lemna minor ${ }^{41}$

A partir do monitoramento de uma série de extratos de plantas medicinais africanas empregando o bioensaio com L. minor, foi identificada atividade fitotóxica em folhas de Laggera decurrens. O fracionamento das folhas guiado pelo bioensaio levou ao isolamento de dois compostos ativos: 3-hidroxitimoquinona e 5-acetoxi-2hidroxitimol (Figura 9). ${ }^{42}$<smiles>CC1=CC(=O)C(C(C)C)=C(O)C1=O</smiles>

3-hidroxitimoquinona<smiles>CC(=O)Oc1cc(C)c(O)c(O)c1C</smiles>

5-acetoxi-2-hidroxitimol

Figura 9. Compostos fitotóxicos isolados de folhas de Laggera decurrens guiado por bioensaio com Lemna minor. 

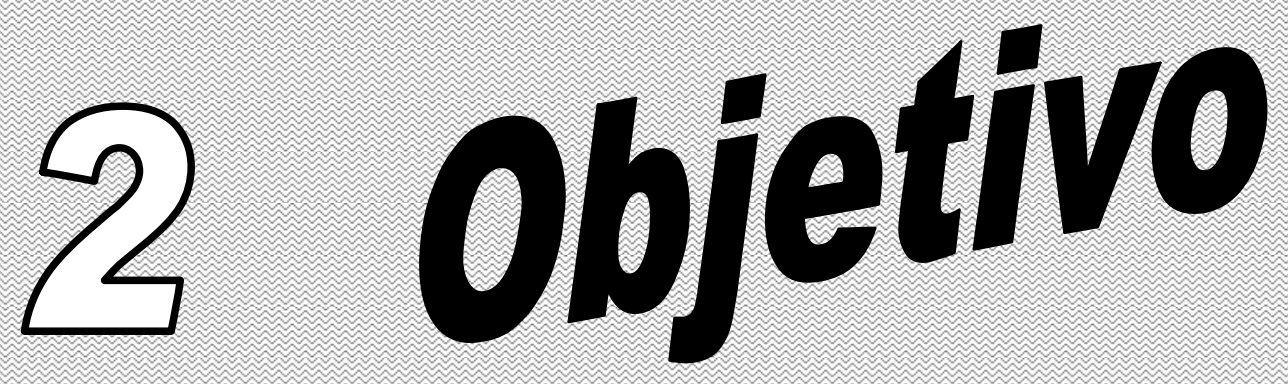

O principal objetivo desse trabal ho é o desenvolvimento de uma metodologia adequada para a identificação, isolamento e caracterização estrutural de substâncias com atividade fitotóxica produzidas por processos fermentativos.

A metodologia desenvolvida utiliza a versatilidade da espectrometria de massas acoplada a cromatografia liquida de alta eficiência para acelerar a etapa de identificação dos compostos ativos, os quais são monitorados por bioensaios de fitotoxicidade empregando Lemna minor. 


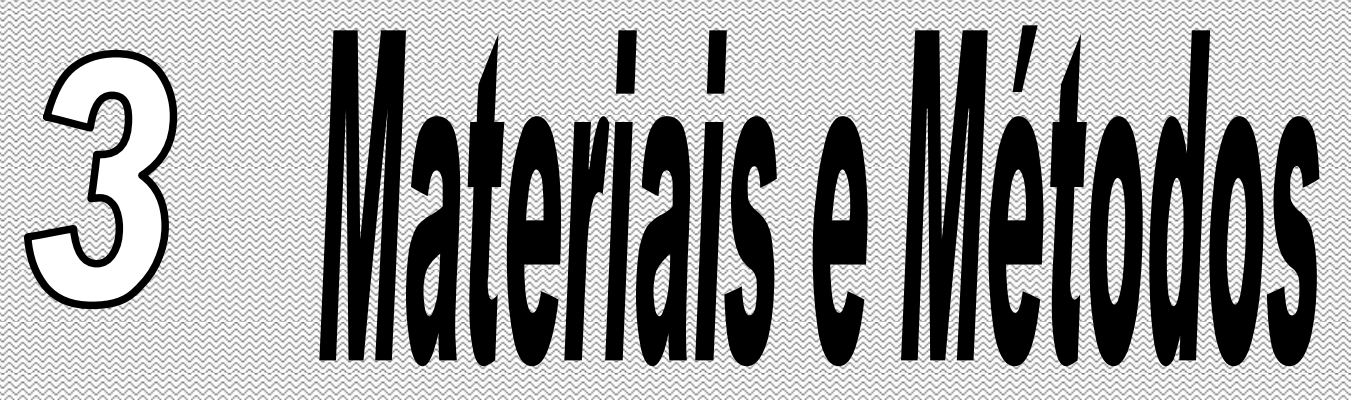

\section{1 - Equipamentos}

- Balança analítica FA 2104N-Celtac ${ }^{\circledR}$

- Estufa de fotoperíodo e alternância de temperatura Eletrolab ${ }^{\circledR}$

- Rota evaporador R-144 BUCHI ${ }^{\circledR}$

-Autoclaves verticais

-Incubadora TE-420 Tecnal ${ }^{\circledR}$

-Espectrômetros de RMN Brucker ${ }^{\circledR}$ DRX-400M Hz e BRUCKER DRX-500M Hz

- Espectrômetros de massas Q-TOF II, Micromass-UK ${ }^{\circledR}$ e Quattro Micro, Waters ${ }^{\circledR}$

- Cromatógrafo líquido de alta eficiência Shimadzu ${ }^{\circledR}$, com injetor automático SIL10AF VP, bomba modelo LC-10AT VP Shimadzu ${ }^{\circledR}$, e detectores de DAD e UV-Vis SPDM 10 AVP Shimadzu ${ }^{\circledR}$

-Espectrofotômetro de Infravermel ho IFTIR-RX ${ }^{\circledR}$ 


\section{2 - Reagentes}

- Todos os reagentes e os solventes orgânicos empregados para a realização dos experimentos foram de grau analítico.

- Para as análises de HPLC utilizou-se solventes de grau cromatográfico (J.T.BACKER, MALLINCKRODT ${ }^{\circledR}$ ) e água purificada em um sistema MilliQ.Millipore ${ }^{\circledR}$.

- As análises de Ressonância Magnética Nuclear (RMN) foram realizadas utilizando clorofórmio deuterado MERCK ${ }^{\circledR}$ para solubilizar as amostras.

\section{3 - Metodologia}

O fluxograma apresentado na Figura 10 ilustra o procedimento empregado neste projeto, para o isolamento e identificação do composto fitotóxico produzido pela bactéria EMB5B.

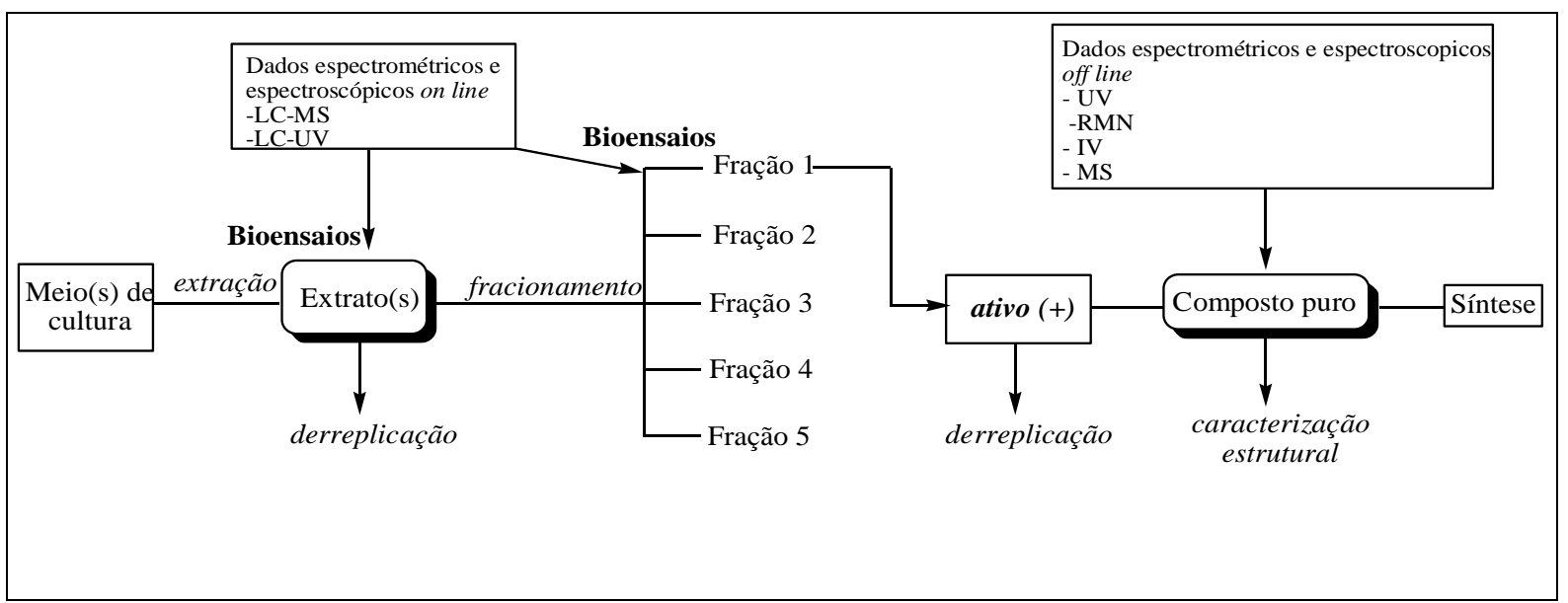

Figura 10. Metodologia empregada para o isolamento de fitotoxinas. 


\section{4 - Isolamento das bactérias e manutenção das cepas}

As cinco bactérias empregadas nesse estudo foram isoladas do esclerócio do fungo fitopatogênico Sclerotium rolfsii, em meio sólido TSBA, pelo grupo do pesquisador Dr. Itamar Soares de Melo (Embrapa Meio Ambiente-Jaguariúna) e identificadas como EMB1B, EMB2B, EMB3B, EMB5B eEMB6B.

Para conservá-las, estas foram repicadas periodicamente em nosso laboratório, em meio TSBA a $25^{\circ} \mathrm{C}$. O manuseio dos microrganismos foi realizado em câmara de fluxo laminar, previamente esterilizada com luz ultravioleta por $30 \mathrm{~min}$. Os repiques foram feitos com uma alça de platina aquecida ao rubro pela chama de um bico de Bunsen.

\section{5 - Identificação das Bactérias}

Para identificação das bactérias foram empregados dois métodos. O primeiro analisa o perfil de ácidos graxos (FAME) e o segundo o gene 16SrDNA.

Os isolados das bactérias foram inicialmente submetidos à identificação pelo método $\mathrm{FAME}^{43}$ através do perfil de ácidos graxos que compõem a membrana celular desses microrganismos. As bactérias a serem identificadas foram cultivadas em meio TSBA, pelo processo de estrias cruzadas, e incubadas a $28 \stackrel{\circ}{\circ}$ por 24 horas. Decorrido este tempo, foram coletadas aproximadamente $40 \mathrm{mg}$ (quatro a seis alças com capacidade para $10 \mu \mathrm{L}$ ) da cultura no 30 quadrante e transferidas para tubos 
Kimax (100 X 13 mm). A seguir, os ácidos graxos presentes na membrana células das bactérias foram derivatizados para metil ésteres. Estes foram dissolvidos em acetato de etila e foram pipetadas e colocadas nos tubos vial. Em seguida, os tubos vial foram inseridos no cromatógrafo gasoso, para a leitura das amostras.

O segundo método utiliza o gene 16SrDNA. O microrganismo foi cultivado em $10 \mathrm{~mL}$ de meio de cultura TSA líquido e incubado por 48 horas à 28드, em shaker, à 120 rpm. A pós esse período, a suspensão bacteriana foi recolhida em tubos de 15 $\mathrm{mL}$ e centrifugado por 5 minutos a $6.000 \mathrm{rpm}$. O sobrenadante foi descartado e o precipitado, ressuspendido em $500 \mu \mathrm{L}$ de TE (Tris-HCl 1 M pH 7,5, 10 mL; EDTA 0,5 M pH 8,0, 2 mL; água destilada, $1000 \mathrm{~mL}$ ). Adicionou-se $30 \mu \mathrm{L}$ de SDS 10\% e 0,5 g de sílica e o material foi agitado em "bead beating" (Biospec products) por 30 segundos, para lise da parede celular. O DNA foi extraído com fenol/ clorofórmio 1:1 e precipitado com isopropanol e $\mathrm{NaCl}(5 \mathrm{M})$. A seguir, o DNA foi lavado com etanol $70 \%$ e seco a $3^{37} \mathrm{C}$. A pós a ressuspensão do material em $50 \mu \mathrm{L}$ de água Milli-Q, este foi estocado a -20C. A amostra foi tratada com RN A se (10mgml-1).

Para amplificar o DNA bacteriano, reações de PCR foram realizadas em um volume final de $50 \mu \mathrm{L}$, contendo $5 \mu \mathrm{L}$ (10 ng) de DNA molde; 0,2 $\mu \mathrm{M}$ do primer 968F (5'-AAC GCG AAG AAC CTT AC -3') e do primer R1387 (5'-CGG TGT GTA CAA GGC CCG GGA ACG-3'); $200 \mu \mathrm{M}$ de cada dNTP (Gibco BRL); 3,75 mM de $\mathrm{MgCl} ; 0,5 \mathrm{U}$ de Taq DNA polimerase (Life Technologies $\left.{ }^{\circledR}\right)$. No experimento foi adicionada uma reação sem DNA como controle negativo. Houve uso do 
termociclador (Gene AMP PCR System 9700) programado para gerar uma desnaturação inicial de $4 \min$ a $94^{\circ} \mathrm{C}, 2$ ciclos a $94^{\circ} \mathrm{C}, 1 \mathrm{~min}$ a $60^{\circ} \mathrm{C}, 1 \mathrm{~min}$ a $72^{\circ} \mathrm{C}, 2$ min; mais 2 ciclos a $94^{\circ} \mathrm{C}, 1 \mathrm{~min} ; 5^{\circ} \mathrm{C}, 1 \mathrm{~min} ; 72^{\circ} \mathrm{C} ; 2 \mathrm{~min}$; mais dois ciclos a $94^{\circ} \mathrm{C}, 1$ $\min , 58^{\circ} \mathrm{C}, 1 \mathrm{~min} ; 72^{\circ} \mathrm{C}, 2 \mathrm{~min}$; mais dois ciclos a $94^{\circ} \mathrm{C}, 1 \mathrm{~min} ; 57^{\circ} \mathrm{C}, 1 \mathrm{~min} ; 72^{\circ} \mathrm{C}, 2 \mathrm{~min}$; mais 2 ciclos a $94^{\circ} \mathrm{C}, 1 \mathrm{~min} ; 56^{\circ} \mathrm{C}, 1 \mathrm{~min} ; 72^{\circ} \mathrm{C}, 2 \mathrm{~min}$; mais 20 ciclos a $94^{\circ} \mathrm{C}, 1 \mathrm{~min}$; $55^{\circ} \mathrm{C}, 1 \mathrm{~min} ; 72^{\circ} \mathrm{C}, 2 \mathrm{~min}$ e uma extensão final de $10 \mathrm{~min}$ a $72^{\circ} \mathrm{C}$. Foi utilizado $5 \mu \mathrm{L}$ da reação para a observação em gel de agarose (1,2\%) de um fragmento de aproximadamente 450 pb. O produto do PCR foi purificado com o kit (Ultra Clean PCR clen-up) de acordo com as instruções do fabricante e sequenciado com o primer R1387.

A identificação foi realizada pelo seqüenciamento de genes, pela amplificação do gene que codifica a subunidade $16 S$ do RNA ribossômico em termociclador (Gene AMP PCRSystem 9700) da bactéria. Após o seqüenciamento, estas foram analisadas por meio do BLASTn (http:/ / www.ncbi.nlm.nih.gov/ BLAST), contra a base de dados (GenBank), onde foi observada a similaridade destas seqüências com o 165 rDNA de espécies já depositadas nesta base de dados. 


\section{6 - Meios de cultura e fermentação}

Todos os meios de cultura líquidos para as fermentações foram preparados em Erlenmeyers, sendo que a razão entre o volume de meio e o espaço foi de no mínimo 1/4, para proporcionar aeração para as culturas, uma vez que as bactérias submetidas à fermentação são aeróbicas.

Os meios foram esterilizados em autoclave vertical a $120^{\circ} \mathrm{C}$ por 30 minutos. Após atingirem temperatura ambiente, eles foram inoculados com as bactérias, utilizando uma alça de platina esterilizada em bico de Bunsen ao rubro, em câmara de fluxo laminar previamente esterilizada por luz ultravioleta por $30 \mathrm{~min}$. Todas as fermentações foram realizadas a $28^{\circ} \mathrm{C}$ e sob agitação em shaker a $130 \mathrm{rpm}$.

\subsection{1- Meio BD (batata - dextrose)}

O meio líquido BD foi preparado utilizando $800 \mathrm{ml}$ de água destilada, $200 \mathrm{ml}$ de caldo de batata e $20 \mathrm{~g}$ de $\mathrm{D}$-glicose, para cada $1000 \mathrm{ml}$ de meio. $\mathrm{O}$ caldo de batata foi preparado com $400 \mathrm{~g}$ de batata para cada $1000 \mathrm{ml}$ de água destilada. As batatas foram previamente pesadas, descascadas e em seguida picadas em cubos pequenos. Estes foram lavados em água corrente e cozidos em uma vasil ha contendo $250 \mathrm{ml}$ de água por 30 minutos. A água resultante do cozimento foi utilizada no preparo caldo de batata e os pedaços de batata restantes foram descartados. O líquido foi transferido para uma proveta e o volume completado para $500 \mathrm{ml}$ com água destilada. 


\subsection{2 - Meios TSB (trypitc-soy-broth), Quínoa e Aveia}

O meio TSB foi preparado com $30 \mathrm{~g}$ de TSB (tryptic soy broth) para cada 1000 $\mathrm{ml}$ de água destilada, conforme as proporções determinadas pelo fabricante. Para dissolver o TSB foi necessário colocar os frascos em banho-maria. As mesmas quantidades usadas para o preparo do meio TSB foram utilizadas para o meio quínoa e o meio de aveia.

\section{7 - Obtenção dos extratos bacterianos}

A pós o período de incubação, o qual foi definido de acordo com a finalidade do experimento, os meios foram filtrados à vácuo, com papel de filtro, para a remoção das células bacterianas, e submetidos a sucessivas extrações líquido-líquido com acetato de etila (1:1, v/ v) em funil de separação. As fases aquosas foram descartadas enquanto que as respectivas fases orgânicas foram reunidas, secas com sulfato de sódio anidro e concentradas a pressão reduzida em rota evaporador.

\section{8 - Bioensaio de fitotoxicidade com Lemna minor}

Os bioensaios foram realizados empregando uma solução dos extratos brutos das bactérias, em uma concentração final de $10 \mathrm{mg} / \mathrm{ml}$, em DMSO. A cada poço da Placa de ELISA, foram adicionadas alíquotas de $30 \mu \mathrm{l}$ dessas soluções. O volume foi completado para $3 \mathrm{ml}$ com meio de cultura Swedish SIS para Lemna minor, ${ }^{44}$ 
produzindo uma concentração final de $100 \mu \mathrm{g} / \mathrm{ml}$ de extrato por poço. Em cada poço foram introduzidas duas folhas agregadas de Lemna minor, visualmente sadias. As placas foram incubadas, a $26{ }^{\circ} \mathrm{C}$ em uma estufa de fotoperíodo, 16 / 8h (luz/ escuro) com lâmpada fria fluorescente. Uma solução de DMSO $1 \%$ em meio de cultura foi usada como branco. A Atrazina, (2-doro-4-etilamino-6-isopropilamino-S-triazina) (Figura 1, pg. 4), herbicida sintético, ${ }^{45}$ foi utilizado como controle, em uma concentração final de $100 \mu \mathrm{g} / \mathrm{ml}$ por poço. O potencial de fitotoxicidade dos extratos foi avaliado visualmente mediante a necrose das folhas ou inibição do crescimento e reprodução, em comparação com o branco, após um período de 7 dias de incubação. Cada ensaio foi realizado em triplicata.

\subsubsection{Manutenção da Lemna}

As folhas de Lemna minor foram cultivadas no laboratório em meio de cultura SIS e conservadas em temperatura e iluminação ambientes. A Tabela 3 mostra os elementos presentes nesse meio.

Tabela 3. Composição do meio de cultura SIS para Lemna minor.

\begin{tabular}{ccc}
\hline & Soluções estoque & Massa de reagente (mg) \\
\hline 1$)$ & $\mathrm{NaNO}_{3}$ & $4250 \mathrm{mg}$ \\
& $\mathrm{KH}_{2} \mathrm{PO}_{4}$ & $670 \mathrm{mg}$ \\
\hline 2$)$ & $\mathrm{MgSO}_{4} \cdot 7 \mathrm{H}_{2} \mathrm{O}$ & $3750 \mathrm{mg}$ \\
\hline 3$)$ & $\mathrm{CaCl}_{2} 2 \mathrm{H}_{2} \mathrm{O}$ & $1800 \mathrm{mg}$ \\
\hline 4$)$ & $\mathrm{Na}_{2} \mathrm{CO}_{3}$ & $1000 \mathrm{mg}$ \\
\hline 5$)$ & $\mathrm{H}_{3} \mathrm{BO}_{3}$ & $500 \mathrm{mg}$ \\
& $\mathrm{MnCl}_{2} \cdot 2 \mathrm{H}_{2} \mathrm{O}$ & $100 \mathrm{mg}$ \\
& $\mathrm{Na}_{2} \mathrm{MoO}_{4} \cdot 2 \mathrm{H}_{2} \mathrm{O}$ & $5 \mathrm{mg}$ \\
& $\mathrm{ZnSO}_{4} \cdot 7 \mathrm{H}_{2} \mathrm{O}$ & $25 \mathrm{mg}$ \\
& $\mathrm{CuSO}_{4} \cdot 5 \mathrm{H}_{2} \mathrm{O}$ & $2,5 \mathrm{mg}$ \\
& $\mathrm{CoCl}_{2}$ & $5 \mathrm{mg}$ \\
\hline 6$)$ & $\mathrm{FeCl}_{3} \cdot 6 \mathrm{H}_{2} \mathrm{O}$ & $42,5 \mathrm{mg}$ \\
& $\mathrm{Na}_{2} \mathrm{EDTA}_{2} 2 \mathrm{H}_{2} \mathrm{O}$ & $70 \mathrm{mg}$ \\
\hline
\end{tabular}


O meio SIS foi preparado com $20 \mathrm{ml}$ das soluções estoque no 1, 2, 3, 4 e 6 e 2 ml da solução estoque no 5 em um balão volumétrico de $1 \mathrm{~L}$. O volume foi completado com água destilada e o meio mantido sob agitação. Em seguida, o meio foi esterilizado em filtro com membrana de $0,2 \mu \mathrm{m}$ de porosidade e mantido sob refrigeração a $10{ }^{\circ} \mathrm{C}$. Para garantir a saúde das pétalas, estas eram lavadas a cada 15 dias. Com o auxílio de espátulas, as pétalas visual mente sadias eram cuidadosamente transferidas para placas de Petri $(20 \mathrm{~cm})$ contendo água destilada e esterilizada, onde permaneceram em repouso por 30 minutos. Em seguida elas foram transferidas para um novo meio de cultura, rico em nutrientes, presente em outra placa, para garantir as condições nutricionais para as plantas.

\subsection{Cromatografia em coluna}

Para a cromatografia líquida em coluna de vidro de dimensões 1.5 × $60 \mathrm{~cm}$. Empregou-se sílica gel (Acros, 60-200) como fase estacionária. A coluna foi empacotada com $20 \mathrm{~g}$ de sílica. A amostra a ser fracionada foi adsorvida na sílica e aplicada no topo da coluna. O fracionamento foi feito com eluição em gradiente crescente de polaridade, utilizando como fase móvel hexano- acetato de etilametanol. As frações coletadas foram analisadas em placas de CCD utilizando como reveladores luz UV com os comprimentos de onda 254 e 366 nm e uma solução aquosa de ácido fosforomolibídico 5\% (p/ v), sulfato cérico $1 \%(p / v)$ e $\mathrm{H}_{2} \mathrm{SO}_{4} 4 \%$ $(v / v)$. 


\subsection{0 - Análises por ESI-MS e ESI-MS/MS}

Para a obtenção dos espectros de massas, os extratos foram dissolvidos em metanol/ acetato de amônio 0,1\% (1:1), para uma concentração final de $200 \mu \mathrm{g} / \mathrm{ml}$ e introduzidos no aparelho por injeção direta via bomba de seringa com fluxo de 20 $\mu \mathrm{l} / \mathrm{min}$. Os espectros foram adquiridos no modo full scan (ESI-MS) em al ta resol ução tanto no modo positivo como no modo negativo. Para a dissociação dos íons utilizouse argônio como gás de colisão (ESI-MS/ MS). Os espectros de massas adquiridos foram analisados no software Mass Lynx versão 4.0.

\subsection{1 - Análises por LC-UV}

As colunas empregadas nos experimentos foram $C_{18}(4,60 \times 250 \mathrm{~mm}) 5 \mu$, Phenomenex e CN (4,60 x 250 mm) 5u, Phenomenex. As fases móveis usadas foram $\mathrm{H}_{2} \mathrm{O} / \mathrm{ACN}(90: 10 \mathrm{v} / \mathrm{v})$ e $\mathrm{H}_{2} \mathrm{O} / \mathrm{ACN}(90: 10$ v/ v) com acetato de amônio 10mM e um fluxo de $1 \mathrm{ml} / \mathrm{min}$, no modo isocrático.

\subsection{2 - Síntese do composto bioativo e homólogos}

A reação, a qual está apresentada na Figura 11, foi realizada em balão de 250 ml, onde 500 mg (4,80 mmol) deácido 3-(R)- hidroxibutírico e 75,8 mg (0,41 mmol) de 
$\mathrm{TsOH} . \mathrm{H}_{2} \mathrm{O}$ foram refluxados em $150 \mathrm{ml}$ de tolueno por 48h, sob agitação vigorosa. $\mathrm{O}$ produto amarelo resultante da reação foi lavado exaustivamente com uma solução aquosa de $\mathrm{NaHCO}_{3}(5 \%$ p/ v) em funil de separação de $500 \mathrm{ml}$. A fase orgânica resultante foi concentrada em rota evaporador sob pressão reduzida.

O mesmo procedimento foi realizado para a reação empregando o ácido (S)-3hidroxibutírico.<smiles>C[C@H](O)CC(=O)O</smiles>

$$
\underset{\substack{\text { tolueno, refluxo } \\ 48 \mathrm{~h}}}{\stackrel{\mathrm{TsOH} . \mathrm{H}_{2} \mathrm{O}}{\longrightarrow}}
$$

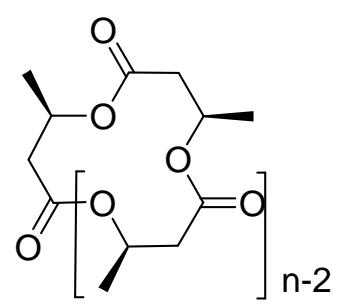

Figura 11. Síntese de oligômeros cíclicos a partir do ácido (R)-3-hidroxibutírico. 

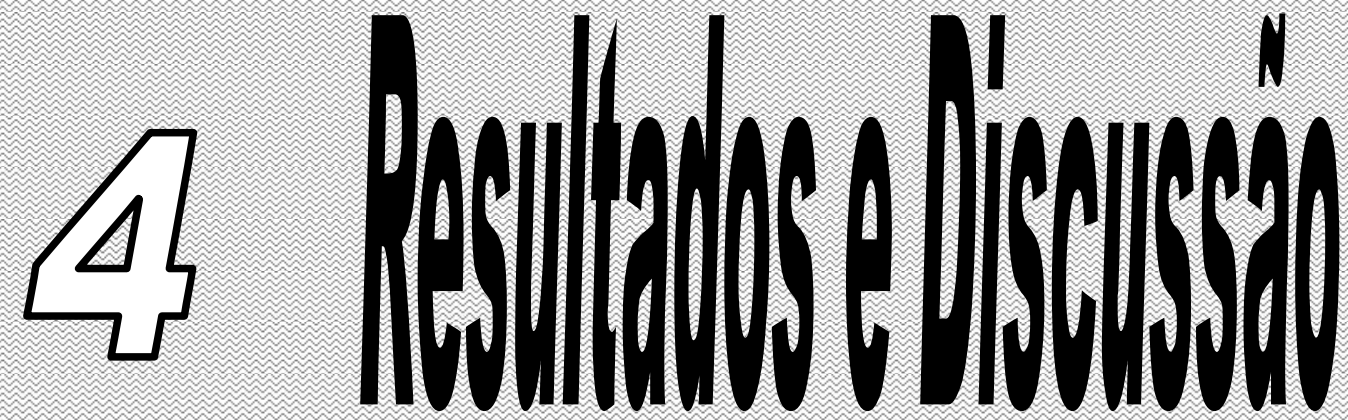

\section{1 - Isolamento e identificação dos microrganismos}

Esta etapa do projeto foi realizada no Laboratório de Microbiologia Ambiental da Embrapa-Jaguariúna, pelo grupo de pesquisa do Dr. Itamar Soares de Melo. Os experimentos que serão apresentados foram realizados com cinco bactérias simbióticas ao fungo fitopatogênico Sclerotium rolfsii.

Sabe-se que o Sclerotium rolfsii é um fungo que causa doenças em uma grande variedade de espécies de dicotiledôneas e monocotiledôneas, sendo, deste modo, responsável por grandes prejuízos na agricultura.46

Foi observado que o crescimento do Sclerotium rolfsii era inibido na presença das bactérias (EMB) em ensaios de antagonismo (microrganismo vs microrganismo). Baseado neste fato iniciou-se um estudo com essas bactérias com o objetivo de utilizá-las para o controle biológico do Sclerotium rolfsii. As bactérias foram isoladas, e as respectivas cepas enviadas para o nosso grupo, para identificarmos os princípios 
ativos responsáveis pela inibição do crescimento do fitopatógeno. Porém, os ensaios de antagonismo e antibiose, realizados in vitro, que avaliaram a inibição do fungo pelas bactérias, apresentaram resultados negativos.

Os mesmos extratos usados no ensaio de anti biose foram submetidos a testes de fitotoxicidade com Lemna minor, onde um apresentou atividade. Consideramos esse resultado de grande relevância, uma vez que foi evidenciada atividade fitotóxica em uma bactéria associada a um fungo fitopatogênico, e em vista disso, estas foram selecionadas para o desenvolvimento deste trabal ho.

O método FAME foi empregado para a identificação dos microrganismos e forneceu informação inicial sobre as bactérias isoladas do fungo fitopatogênico Sclerotium rolfsii (Tabela 4).

Tabela 4. Identificação preliminar das bactérias pelo método FAME.

\begin{tabular}{lcc}
\hline Código & Bactéria & IS \\
\hline EMB1B & Bacilus subtilis & 0,746 \\
EMB2B & NI & 0,474 \\
EMB3B & Pseudomonas cepacia & 0,927 \\
EMB5B & NI & 0,322 \\
EMB6B & Paenibacillus lentimorbus & 0,583 \\
\hline
\end{tabular}

IS =índice de similaridade; NI =bactéria não identificada

O índice de similaridade (IS) de 0,5 é considerado o valor mínimo para a identificação do microrganismo. Uma vez que os IS para as bactérias EMB2B e EMB5B foram 0,474 e 0,322, respectivamente, estas não foram identificadas por esta metodologia.

A bactéria EMB5B, a qual apresentou a maior atividade fitotóxica foi submetida à identificação utilizando o gene 16SrDNA . 
A seqüência parcial de nucleotídeos obtida através da extração do DNA da bactéria apresentou 93\% de identidade com seqüências de Burkholderia gladioli (EU090890.1, EU024170.1, AY586515.1, AY268165.1, AY268164.1, AY268163.1, DQ355169.1) pela analise BLAST. Identidade de seqüência de 16SrDNA acima de 97,5\% indica que a linhagem pertence à mesma espécie segundo Stackebrandt \& Goebel, 1994.47 Assim, pôde-se obter apenas informações sob o gênero da bactéria de interesse, Burkholderia sp.

Para simplificar a apresentação do trabalho, as bactérias serão mencionadas ao longo do texto como bactérias EMB1B (Bacillus subtilis), EMB2B (não identificada), EMB3B (Pseudomonas cepácia), EMB5B (Burkhoderia sp.) e EMB6B (Paenibacillus lentimorbus).

Bactérias pertencentes ao gênero Burkholderia sp. são organismos altamente versáteis, explorados como agentes de biocontrole, biorremediação e promotores do crescimento de plantas. São também causadora de doenças infecciosas, especialmente a fibrose cística. Extratos de Burkholderia cepacia podem ser usados para o controle de doenças em sementes e raízes de plantas. Essas bactérias podem colonizar a rizosfera de inúmeras plantações incluindo milho, arroz, pêssego, e conseqüentemente aumentar o rendimento das colheitas. ${ }^{48,49,50}$

Um exemplo relevante de bactéria pertencente a esse gênero é a Burkholderia ambifaria, atualmente um dos agentes de biocontrole mais estudados. O extrato AMMDt possui atividade contra o Pythium aphanidermatum, fungo fitopatogênico responsável pelo tombamento pré e pós emergente em pêssego e também contra 
A phan omyces euteiches , que causa apodrecimento de maçãs. ${ }^{51,52}$

Um outro aspecto interessante em relação às bactérias do gênero Burkholderia, foi revisado recentemente na literatura. Fungos fitopatogênicos pertencentes ao gênero Rhizophus são responsáveis pela inibição do crescimento das sementes de arroz, efeito causado pela fitotoxina rizoxina (Figura 12). Porém, estudos de microscopia mostraram que a fitotoxina é produzida pelas bactérias do gênero Burkholderia que vivem no organismo do fungo, isto é, bactérias endossimbiontes, e não pelo fungo. Acredita-se que os sinalizadores químicos oriundos da associação fungo-bactéria sustentam a produção da fitotoxina. ${ }^{53,54}$

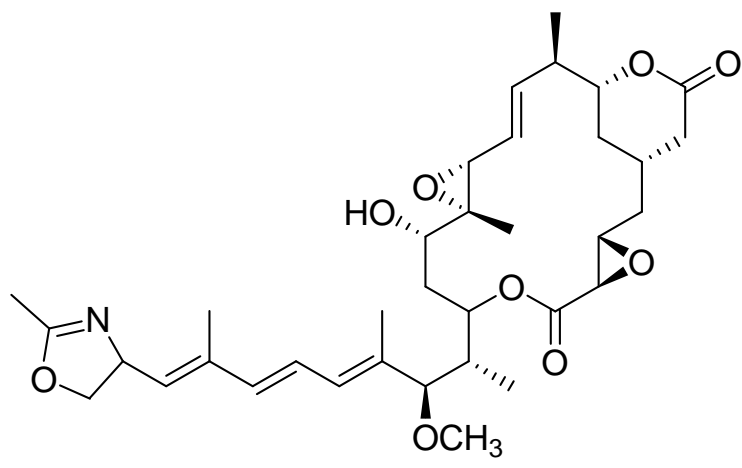

Rizoxina

Figura 12. Estrutura da fitotoxina rizoxina produzida pela bactéria endossimbionte Burkholderia rhizoxina.

\section{2 - Screening biológico dos extratos brutos empregando Lemna minor}

O isolamento do composto ativo foi guiado através do bioensaio com Lemna minor. Para a primeira triagem, as fermentações foram feitas em Erlenmeyers de 250 
$\mathrm{ml}$, sendo que cada um continha $50 \mathrm{ml}$ de meio de cultura líquido BD. Cada bactéria foi cultivada em duplicata por um período de 5 e 11 dias.

Segundo dados da literatura, podem-se empregar solventes orgânicos para dissolver esses compostos a serem testados. Alguns solventes como acetona, clorofórmio, etanol e DMSO, foram testados para verificar sua toxicidade frente às pétalas de L.minor. O melhor resultado foi obtido com DMSO, o qual promoveu uma melhor solubilização dos extratos. O DMSO foi empregado na concentração máxima permitida ( $1 \% \mathrm{v} / \mathrm{v})$. Esse solvente foi selecionado porque é capaz de dissolver moléculas polares e apolares e principalmente por apresentar baixa toxicidade, em relação aos demais. ${ }^{5}$

Os ensai os de fitotoxicidade foram realizados com os extratos brutos orgânicos obtidos das fermentações das bactérias EMB1B, EMB2B, EMB3B, EMB5B e EMB6B bem como extratos obtidos de outras fontes naturais. A Tabela 5 apresenta a diversidade dos extratos submetidos ao bi oensaio com L.min or.

Tabela 5. Diversidade de organismos submetidos ao bioensaio de fitotoxicidade com Lemna minor

\begin{tabular}{cccc}
\hline Fontes dos extratos & Quantidade & Ativos & Ativos(\%) \\
\hline Cianobactérias & 95 & 3 & 2.8 \\
Actinomicetos & 17 & 9 & 17 \\
Bactérias Embrapa & 5 & 1 & 20 \\
\hline
\end{tabular}

Dentre os extratos avaliados, optamos por trabalhar com as bactérias EMBRAPA por que são bactérias simbióticas isoladas de um fungo fitopatogênico, o 
Sclerotium rolfsii. Uma grande variedade de metabólitos secundários são produzidos por microrganismos simbióticos, isolados de eucariontes. Muitos desses compostos possuem atividade biológica56, como por exemplo, a substância rizobitoxina (Figura 13) produzida pela bactéria Bradyrhizobium elkani a qual promove clorose em soja. Inicialmente foi considerada uma toxina produzida por um legume. Porém, mais tarde foi demonstrado que a inativação genética da produção desta toxina pela bactéria simbionte diminuiu os efeitos danosos causado na soja.57<smiles>NC(CO)COC=CC(N)C(=O)O</smiles>

Rizobitoxina

Figura 13. Substância rizobitoxina produzida pela bactéria simbionte Bradyrhizobium elkani.

Com base nesses exemplos sugerimos que as bactérias Embrapa poderiam ser fontes promissoras para produção de novos compostos bioativos, em especial de fitotoxinas. A Tabela 6 apresenta os resultados da primeira triagem realizada com os extratos dessas bactérias, as quais foram fermentadas por períodos de 5 e 11 dias. 
Tabela 6. Resultado dos testes de fitotoxicidade dos extratos orgânicos das bactérias EMB

\begin{tabular}{|c|c|c|}
\hline Bactéria & Período de fermentação & $\begin{array}{l}\text { Atividade } \\
\text { fitotóxica }\end{array}$ \\
\hline EMB1B & $\begin{array}{l}5 \text { dias } \\
11 \text { dias }\end{array}$ & $\begin{array}{l}-- \\
-- \\
\end{array}$ \\
\hline EMB2B & $\begin{array}{l}5 \text { dias } \\
11 \text { dias }\end{array}$ & $\begin{array}{ll}-- \\
\cdots\end{array}$ \\
\hline EMB3B & $\begin{array}{l}5 \text { dias } \\
11 \text { dias }\end{array}$ & $\begin{array}{l}-- \\
-- \\
\end{array}$ \\
\hline EMB5B & $\begin{array}{l}5 \text { dias } \\
11 \text { dias }\end{array}$ & $\begin{array}{c}--- \\
+++ \\
\end{array}$ \\
\hline EMB6B & $\begin{array}{l}5 \text { dias } \\
11 \text { dias }\end{array}$ & $\begin{array}{l}-- \\
--\end{array}$ \\
\hline
\end{tabular}

$(+++)$ extrato ativo; ( - - ) extrato inativo; ( + + -) extrato moderadamente ativo

A Figura 14 apresenta a foto relativa ao bioensaio dos extratos fermentados por 11 dias, o qual possibilitou selecionar uma bactéria EMB5B entre as demais.

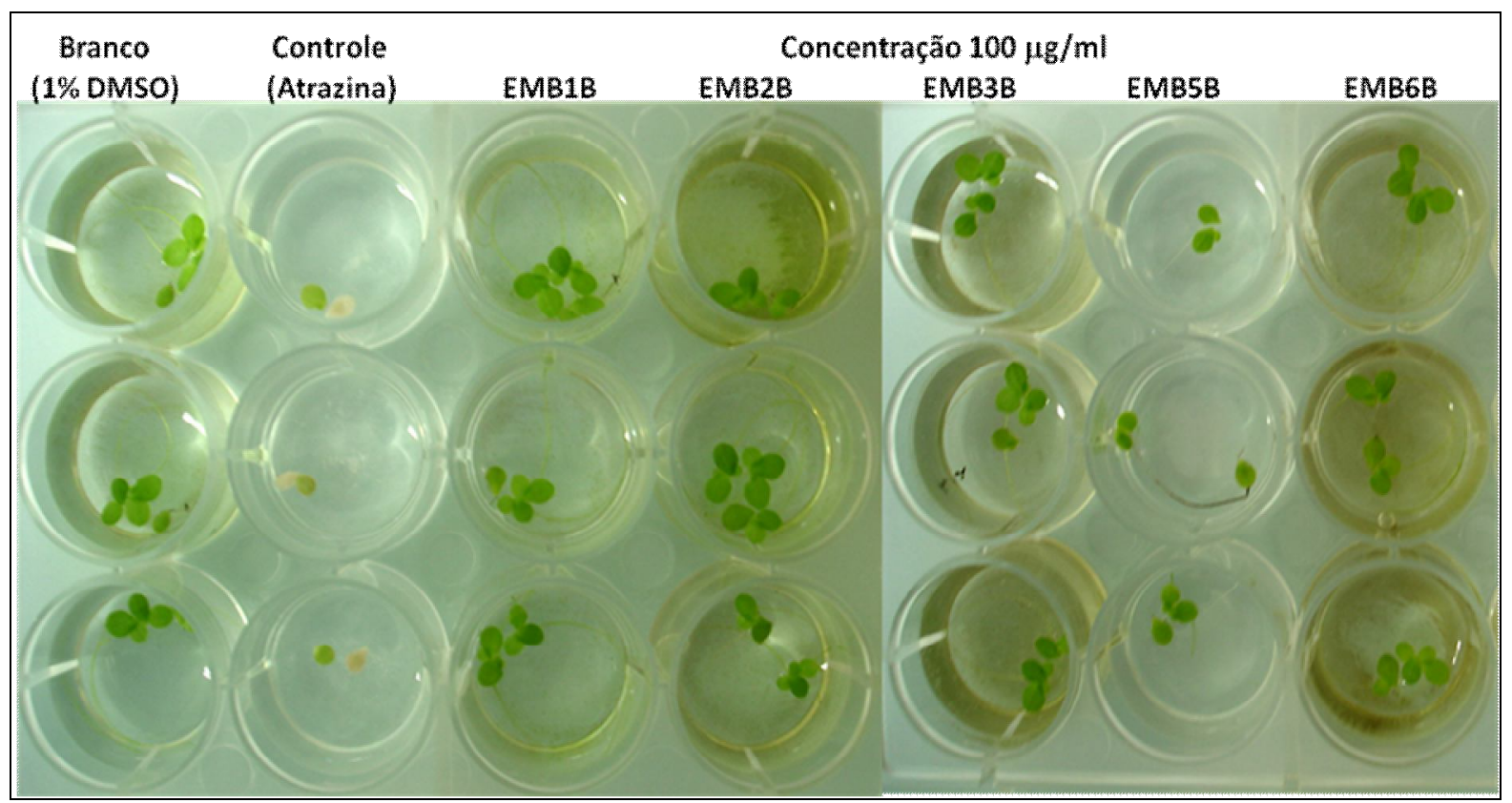

Figura 14. Ensaio de fitotoxicidade das bactérias EMB1B, EMB2B, EMB3B, EMB5B e EMB6B com $L$. minor, fermentadas por 11 dias em meio BD a $28 \mathrm{C}$.

Como pode ser observado na figura acima, na primeira coluna referente ao branco (meio SIS + 1\% de DMSO), houve a multiplicação das pétalas de Lemna e elas 
permaneceram visualmente sadias. Na segunda coluna, referente à atrazina (controle), podemos observar que ocorreu necrose e inibição da multiplicação e do crescimento das pétalas.

A multiplicação e o aspecto das pétalas das plantas presentes nos poços referentes às bactérias EMB1B, EMB2B, EMB3B e EMB6B (3a $4^{a}$, 5a e 7a colunas respectivamente), foram semelhantes ao branco. Através destes resultados concluímos, que esses extratos não apresentaram nenhuma atividade fitotóxica.

Na 6a coluna, onde está presente o extrato EMB5B, podemos observar que ocorreu inibição da multiplicação e do crescimento das pétal as em relação ao branco. Além disso, ocorreu um leve amarelamento, indicando o início de necrose das pétalas.

Baseado no resultado deste ensaio, constatamos que a bactéria EMB5B, quando fermentada por 11 dias produziu um extrato com atividade fitotóxica contra a planta Lemna minor. Desta forma, este microrganismo foi selecionado entre os demais, para a identificação e isolamento do seu princípio ativo.

\section{3 - Comparação entre os perfis químicos dos extratos}

O estudo do perfil químico dos extratos por espectrometria de massas com fonte de ionização por electrospray foi realizado com o objetivo de determinar as massas moleculares dos metabólitos secundários produzidos pelas bactérias, o que possibilitou submetêlos a um estudo de desreplicação bem como fazer a comparação 
entre os perfis e a diversidade metabólica desses extratos.

A inserção direta dos extratos brutos das bactérias em um espectrômetro de massas operando com fonte de electrospray fornece importantes informações sobre a composição das amostras, bem como o perfil dos metabólitos secundários produzidos e suas respectivas massas moleculares devido a falta de fragmentação, a qual é característica da ionização por electrospray. Esta metodologia tem possibilitado a criação de bancos de dados de massas moleculares dos metabólitos e tem sido usado na classificação quimiotaxonômica de microrganismos. ${ }^{58}$

Julian e colaboradores ${ }^{59}$ e Higgs e colaboradores ${ }^{60}$ utilizaram esta metodol ogia para estimar e diferenciar metabólitos secundários em extratos de microrganismos.

No perfil químico dos extratos bacterianos obtido por ESI-MS, os espectros foram adquiridos tanto no modo positivo como no modo negativo. Porém, no modo negativo a ionização dos compostos não foi eficiente. Em vista disso serão apresentados os espectros de massas adquiridos no modo positivo. O fator que determina a eficiência da ionização é, principalmente, a estrutura química dos analitos. Substâncias que apresentam grupamentos básicos, principalmente aminas, amidas e ésteres, normalmente são analisadas em modo positivo, dadas à relativa facilidade de protonação desses grupos funcionais. Por outro lado, substâncias contendo funções ácidas, tais como ácidos carboxílicos e fenóis, são mais facilmente desprotonadas e, conseqüentemente, são analisadas em modo negativo. A natureza do solvente utilizado e o pH são igualmente importantes na geração de íons positivos e negativos. Íons positivos são geralmente analisados empregando-se soluções da 
amostra em metanol e com baixos val ores de $\mathrm{pH} .61$

A Figura 16 apresenta os espectros de massas no modo full scan dos extratos brutos das bactérias EMB1B, EMB2B, EMB3B, EMB5B e EMB6B, cultivadas em meio BD por um período de 11 dias. 


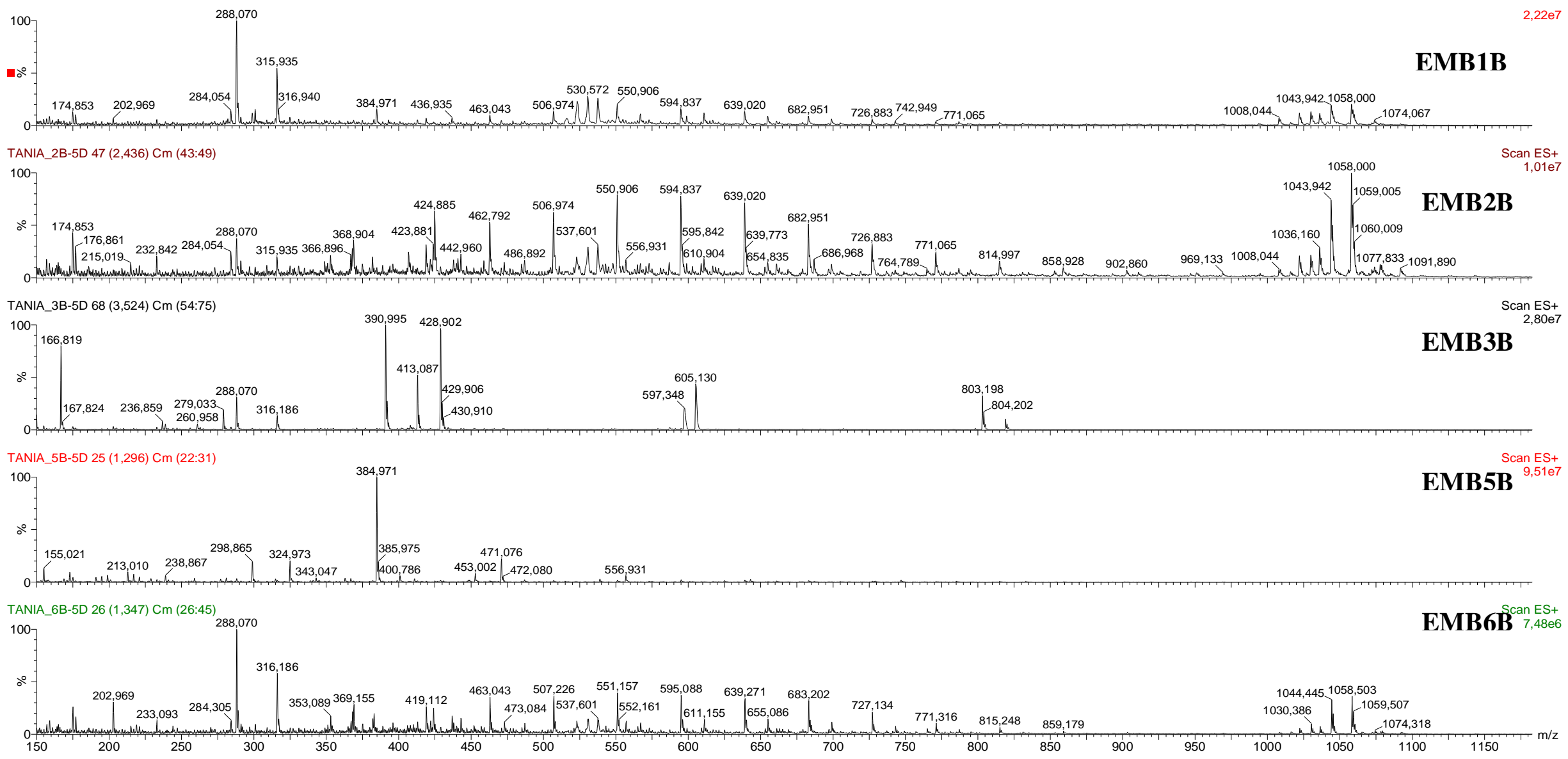

Figura 15. Espectros de massas ESI ${ }^{+}$e potencial do cone 55V dos extratos orgânicos de EMB1B e, EMB2B, EMB3B, EMB5B e EMB6B, fermentados por 5 dias em meio BD. 
Os espectros apresentados mostram uma grande diversidade de metabólitos secundários nesses extratos. Em termos de composição dos extratos, os perfis das bactérias EMB1B e EMB2B são bastante semelhantes. Outro fato relevante é que os extratos EMB1B, EMB2B e EMB6B apresentam uma semelhança de metabólitos secundários na faixa de massas de m/z 1008 a 1060. O perfil do espectro de massas do extrato EMB5B, o qual apresentou atividade fitotóxica, mostrou-se bastante diferente, quando comparado com os demais espectros. 


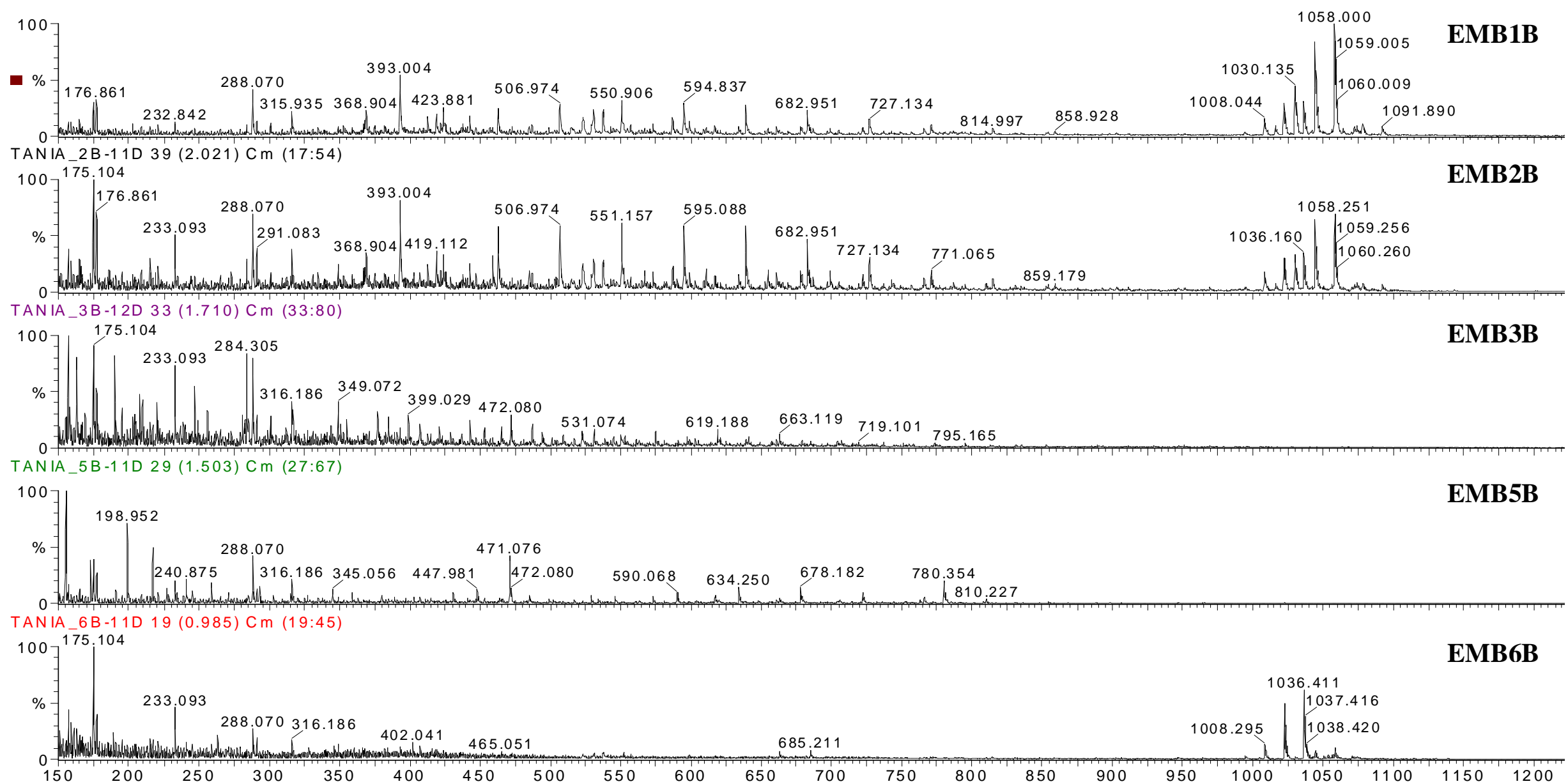

Figura 16. Espectros de massas ESI ${ }^{+}$e potencial do cone $55 \mathrm{~V}$, dos extratos orgânicos de EMB1B e, EMB2B, EMB3B, EMB5B e EMB6B,

fermentados por 11 dias em meio BD 
Quando comparamos os espectros de massas relativos à fermentação das bactérias por 5 e 11 dias (Figura 15 e Figura 16), observamos que o perfil de metabólitos para as bactérias EMB1B, EMB2B e EMB6B não variou significativamente, com o aumento dos dias de fermentação na região da faixa de massas de m/z 1008 a 1060.

Em especial para a bactéria EMB3B, foi observada grande variação no perfil de metabólitos para os dois períodos. Os perfis de metabólitos para a bactéria EMB5B indicaram um aumento da diversidade de metabólitos produzidos pela mesma, devido à presença de maior número de sinais no espectro referente à fermentação por 11 dias.

No perfil cromatográfico, obtido por LC-UV (Figura 17) pode ser observado grande variação de metabólitos entre os extratos EMB6B, EMB5B e EMB3B. Os picos variam entre si em relação ao $t_{R}$ e intensidade. Já os cromatogramas dos extratos EMB1B e EMB2B são similares. Ambos apresentam 3 picos em $t_{R}$ 2,4; 2,7 e 3,8 minutos, com intensidades semel hantes entre si.

Podemos observar que o perfil metabólitos dos extratos produzidos pela bactéria EMB5B, por LC-UV e ESI-MS, fornece informações semelhantes sobre a variação de suas composições em função do tempo. Entretanto, o perfil obtido pela ESI-MS nos dá mais informações a respeito da composição de cada extrato.62 

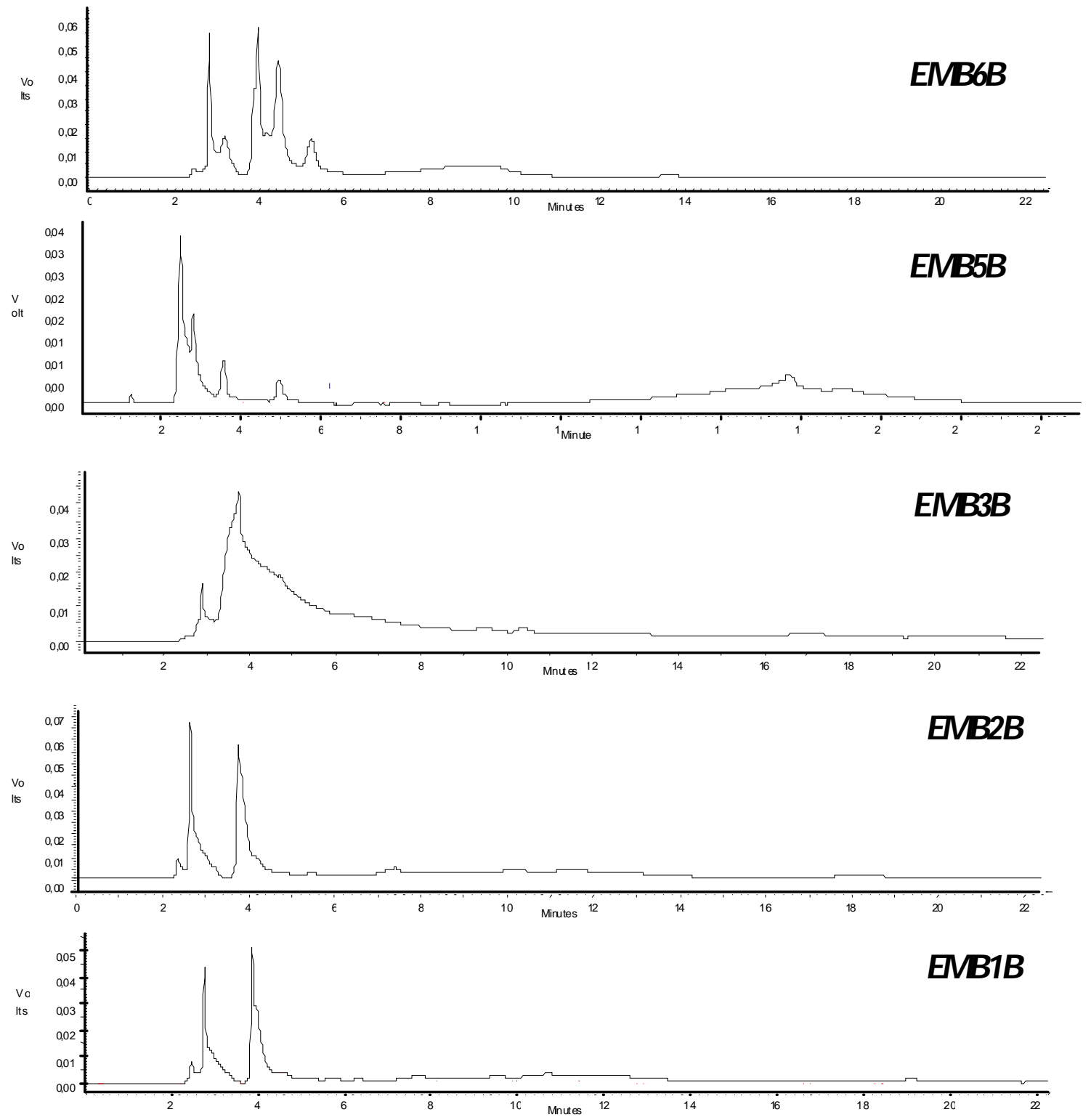

Figura 17. Cromatogramas de LC-UV dos extratos das bactérias EMB obtidos com 11 dias de fermentação. Fase móvel $\mathrm{H}_{2} \mathrm{O} / \mathrm{ACN} 10 \%$, coluna C18 (4.60 x $\left.250 \mathrm{~mm}\right)$, modo isocrático e fluxo 1 $\mathrm{mL} / \mathrm{min}$ e $\lambda=215 \mathrm{~nm}$. 
Mediante a pesquisa na Biblioteca de Produtos N aturais (Chapman $\&$ Hall), os metabólitos secundários na faixa de massas de m/z 1008 a 1060 foram atribuídos à presença de surfactinas, lipopeptídeos com grande atividade surfactante produzidas principalmente por Bacillus sp (Figura 18). Foram identificados, neste extrato, os compostos Surfactina $A_{1}$ a qual apresentou sinal de $m / z[M+H]+1008$, os sinais de $\mathrm{m} / \mathrm{z}[\mathrm{M}+\mathrm{H}]+1022$ e m/z [M + N a]+1044 foram atribuídos à Surfactina $\mathrm{B}_{1}$ e a Surfactina C2apresentou sinais de $\mathrm{m} / \mathrm{z}[\mathrm{M}+\mathrm{H}]+1037$ e $\mathrm{m} / \mathrm{z}[\mathrm{M}+\mathrm{Na}]+1059$.

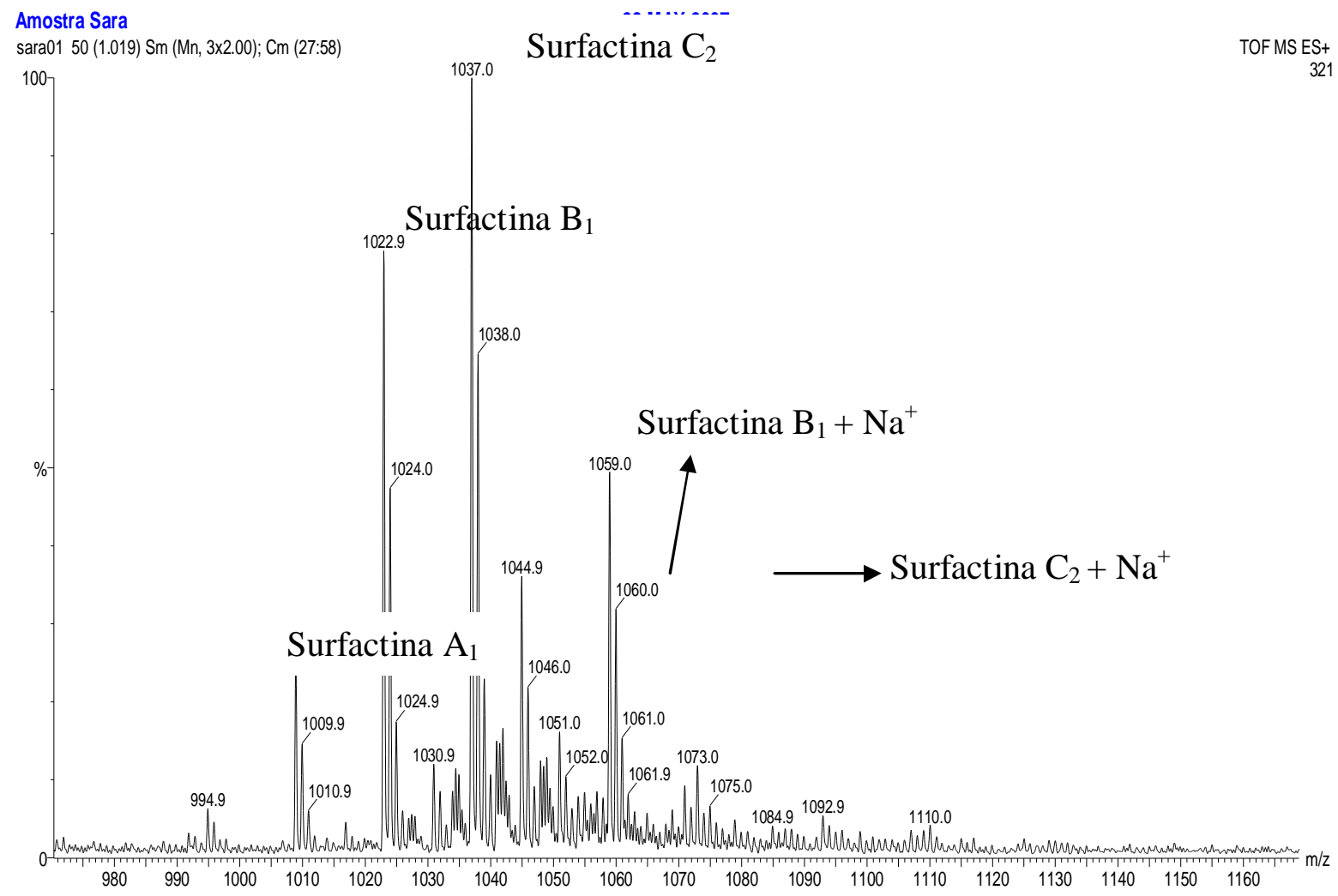

Figura 18. Sinais que caracterizam a presença de surfactinas no extrato EMB1B.

Esta classe de compostos se caracteriza pela existência de peptídeos ligados a 
ácidos graxos, sendo que a porção protéica da molécula pode ser neutra ou aniônica, e os aminoácidos estão freqüentemente dispostos em uma estrutura cíclica (Figura 19). 63,64

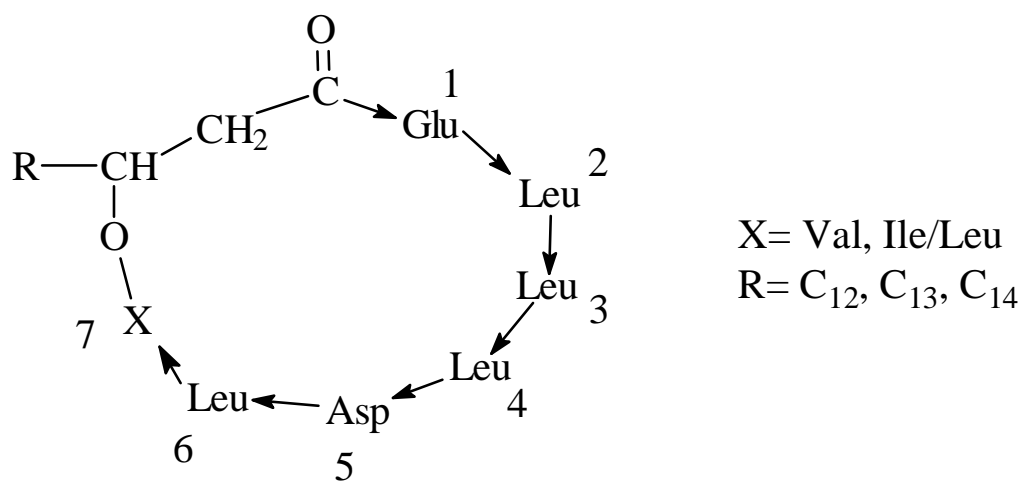

Figura 19. Estrutura geral das surfactinas.

O espectro de ESI-MS/MS obtido para o sinal de $\mathrm{m} / \mathrm{z}[\mathrm{M}+\mathrm{H}]^{+} 1037$ possibilitou caracterizar a seqüência de peptídeos da surfactina $C_{2}$ (Figura 20). 


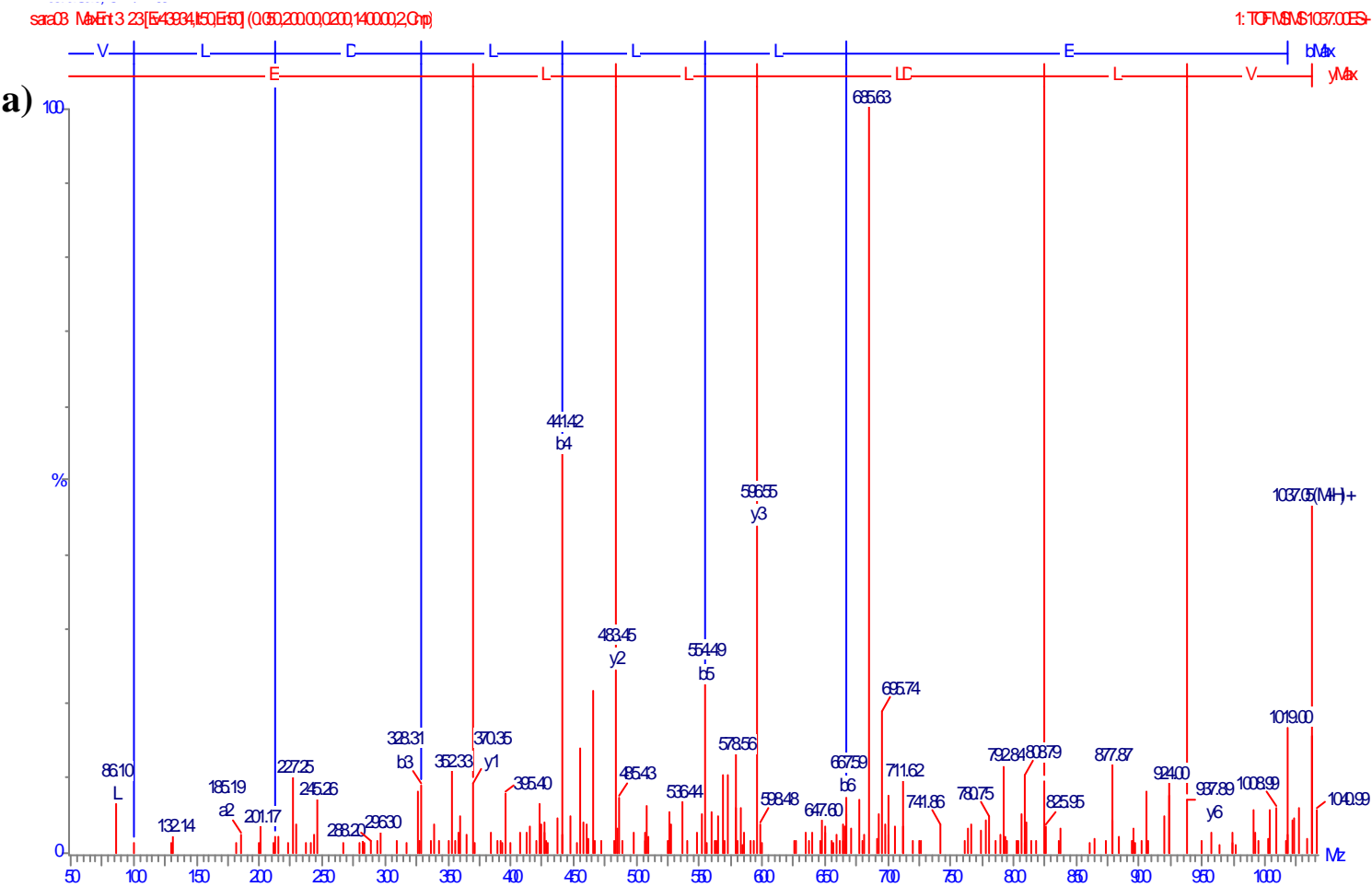

b)

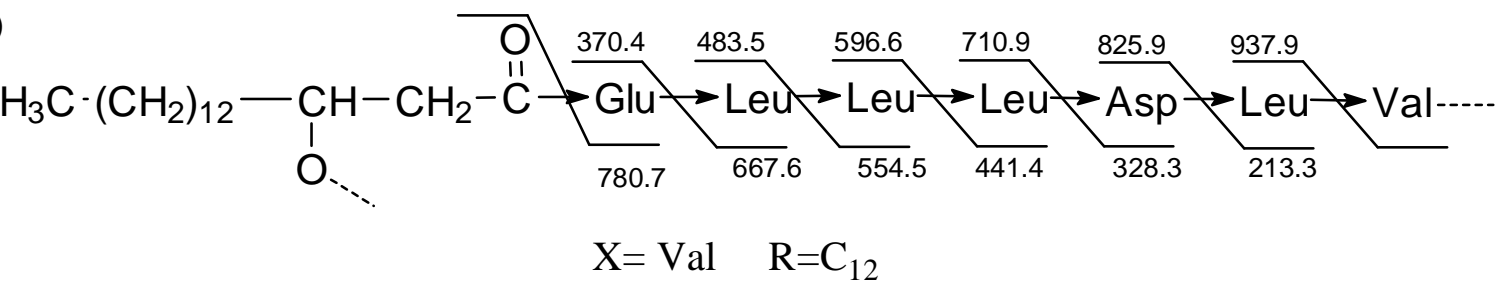

Figura 20. a) Espectro de ESI-MS/MS do sinal de $m / z(M+H)^{+} 1037$, obtido em modo positivo. b) Seqüência de peptídeos da Surfactina $C_{2}$.

A presença de surfactinas nos extratos EMB1B, EMB2B e EMB6B é uma indicação quimiotaxonômica de que a identificação das bactérias por FAME está correta, pois segundo esta metodologia a bactéria EMB1B é um Bacilus subtilis e a bactéria EMB6B é um P aenibacillus lentimorbus, ambas produtoras de surfactinas. 


\section{4 - Efeito do tempo de cultivo na produção de fitotoxinas}

Existe um gama enorme de variáveis que podem ser testadas para a otimização do processo de produção de metabolitos secundários, como temperatura, fontes de carbono e nitrogênio, aeração, tempo, pH entre outros. N esta etapa foi testada a influencia do tempo de fermentação para a produção das fitotoxinas.

Empregando o bioensaio de fitotoxicidade foi possível verificar a influência do tempo de fermentação sobre a fitotoxicidade dos extratos. O extrato EMB5B-5dias não apresentou atividade contra L. minor, e no extrato EMB5B-11dias observou-se uma atividade fitotóxica bastante pronunciada. Em função disso, dois fatores foram estudados: o tempo de fermentação e a composição do meio de cultivo.

Em relação à influência do tempo de fermentação na atividade do extrato, podemos observar na Figura 21, o bioensaio realizado com os extratos fermentados por períodos de 5, 11, 17 e 21 dias. 


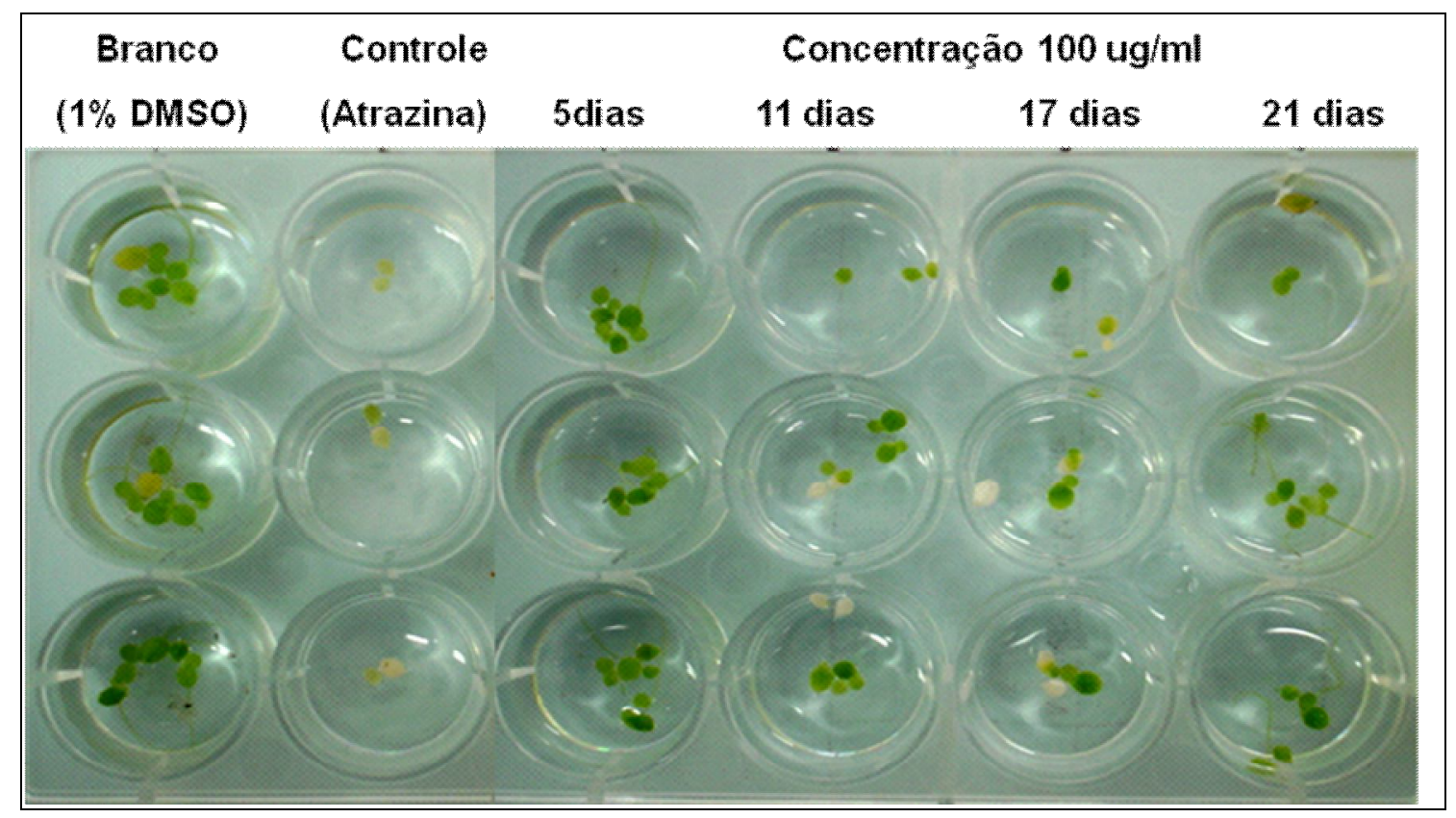

Figura 21. Ensaio de fitotoxicidade da bactéria EMB5B com $L$. minor, fermentadas por $5,11,17$ e 21 dias em meio BD a 28 C.

Podemos observar que o extrato EMB5B-5dias não apresentou atividade (3a coluna), uma vez que a multiplicação e o aspecto das fol has de L. minor foram similares ao branco (1\% DMSO). Já na fermentação por 11 dias, presente na quarta coluna, foi observado início de necrose e inibição da multiplicação das pétalas. Com o aumento do tempo de fermentação para 17 dias, a atividade observada para o extrato foi semel hante ao observado para o cultivo de 11 dias. E para o extrato EMB5B-24dias, presente na $6^{a}$ coluna, a fitotoxicidade do extrato diminuiu, uma vez que a necrose e inibição da multiplicação das pétalas foram menores em relação aos extratos obtidos com 11 e 17 dias.

O perfil dos metabólitos obtido por ESI-MS esta apresentado na Figura 22. Para a fermentação com 5 dias é observado poucos sinais no espectro de massas, indicando a baixa produção de metabólitos neste período. Com o aumento do tempo 
de fermentação para 11 dias, foi observado um aumento na diversidade de metabólitos e este permanece inalterado até o período de 17 dias. Podemos observar também uma grande semelhança entre o perfil dos metabólitos secundários nesses dois períodos.

Ao 21 - dia verifica-se a supressão e diminuição da intensidade de alguns sinais assim como o aparecimento de novos picos, o que indica que a bactéria está metabolizando/ consumindo alguns metabólitos que produziu anteriormente. 


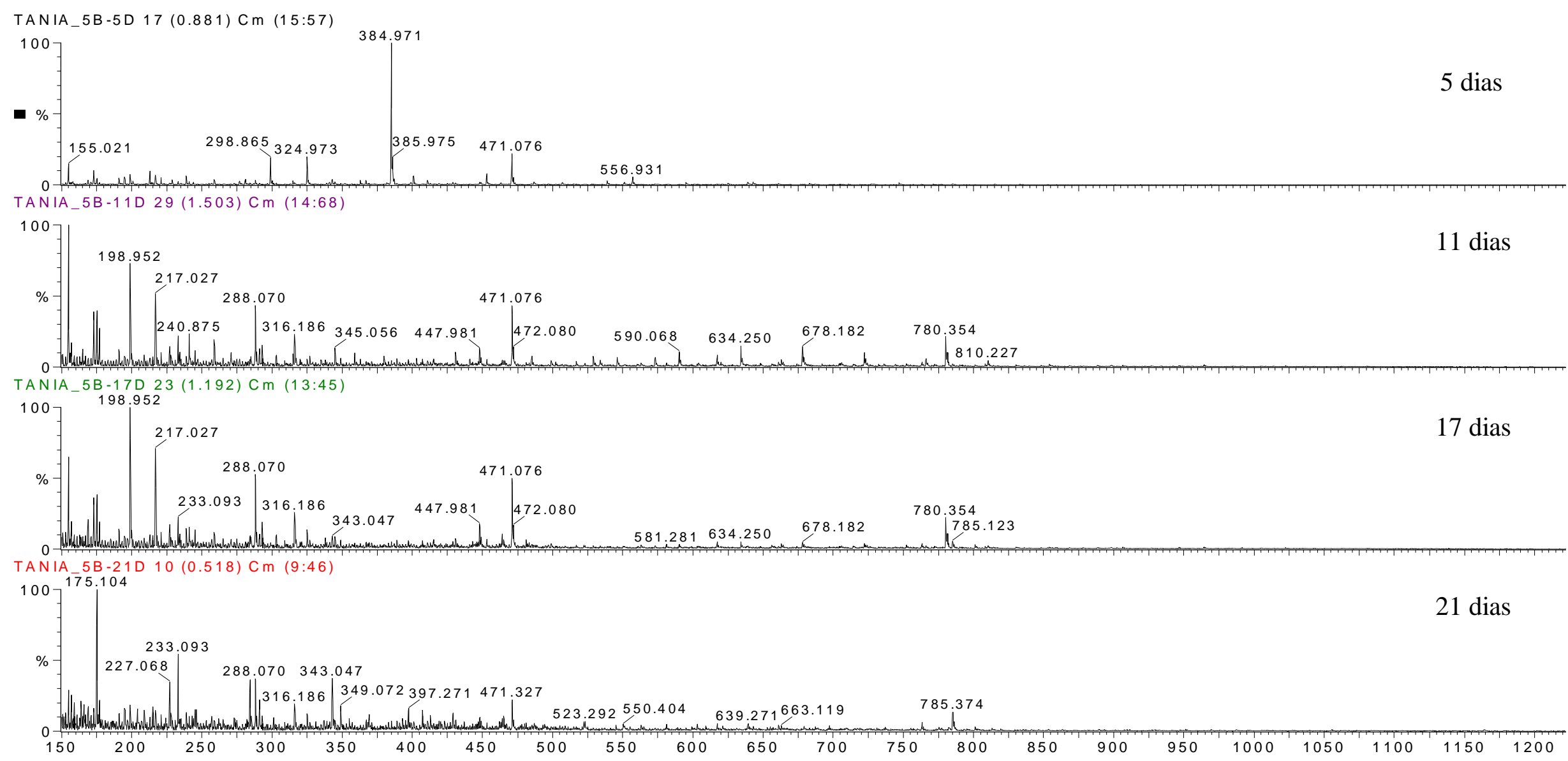

Figura 22. Espectros de massas ESI ${ }^{+}$da bactéria EMB5B com 5, 11, 17 e 21 dias de fermentação, a $28^{\circ} \mathrm{C}$ em meio BD. 
Na Figura 23, apresentamos os cromatogramas dos extratos EMB5B com 5, 11 , 17 e 21 dias de fermentação, obtidos por LC-UV. Através da análise desses cromatogramas verificamos uma grande variação entre os $t_{R}$ e as áreas de alguns picos e em função do período de fermentação. A variação mais significativa foi o pico em $t_{R}=17,8$ min, que aparece nos cromatogramas referentes aos extratos EMB5B-11 dias e 17 dias. Da mesma forma que o perfil obtido por ESI-MS, o espectro de UV evidencia que o microrganismo produz diferentes compostos detectáveis devido à variação do período de fermentação. 

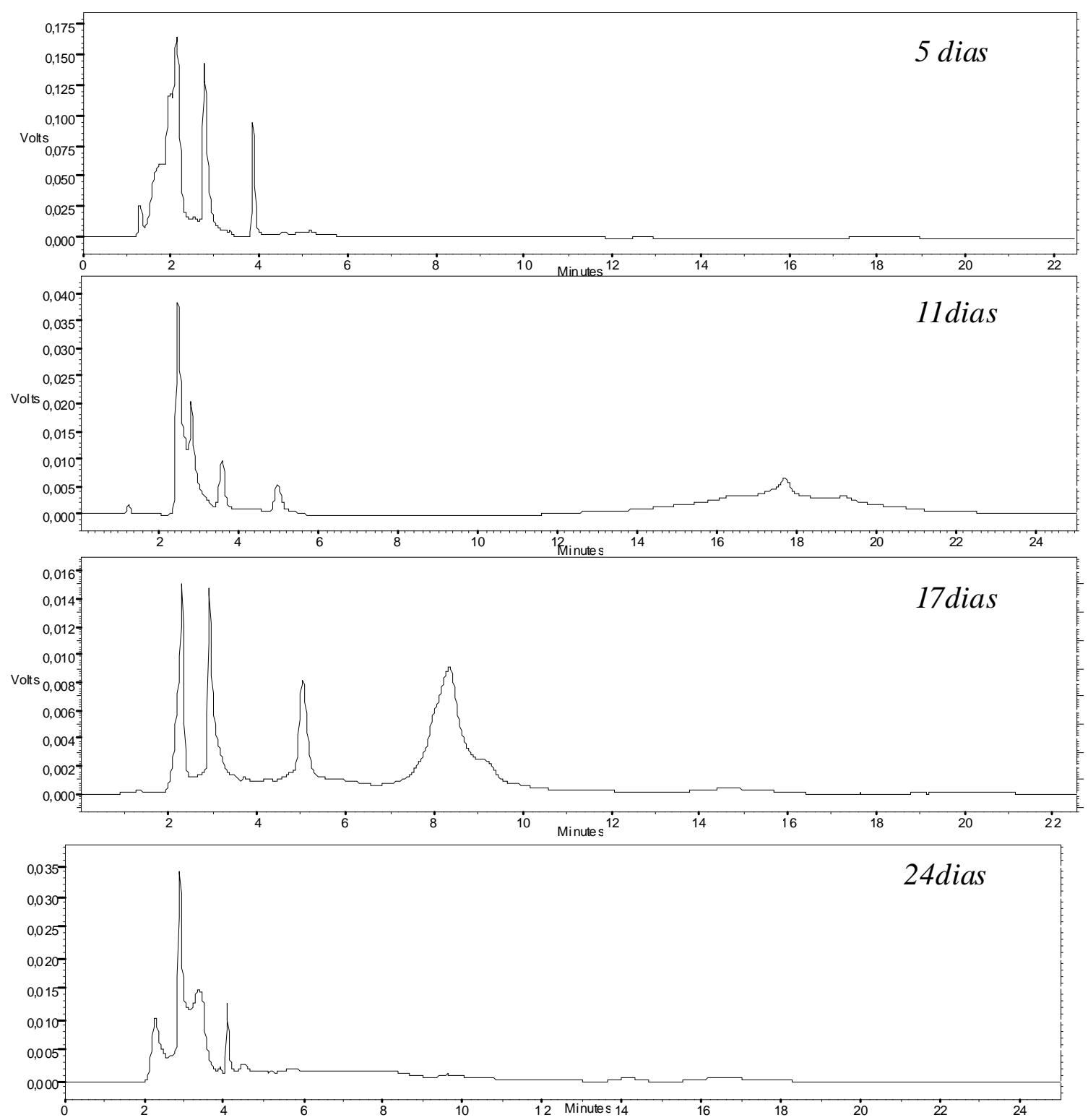

Figura 23. Cromatogramas de LC-UV dos extratos EMB5B obtidos em dias diferentes de fermentação. Fase móvel: $\mathrm{H}_{2} \mathrm{O} / \mathrm{ACN} 10 \%$, coluna C18 $(4.60 \times 250 \mathrm{~mm})$, fluxo $1 \mathrm{ml} / \mathrm{min}$ em 215 $\mathrm{nm}$. 
Os estudos realizados com esses extratos confirmam a variação da atividade fitotóxica em função do tempo de cultivo da bactéria EMB5B. Haja visto, que a presença do composto responsável pela atividade fitotóxica no extrato bruto, deve ter uma concentração mínima necessária para que possa responder ao bioensaio com L. minor.

A determinação da maior fitotoxicidade dos extratos através do bioensaio foi uma etapa importante para que pudéssemos aumentar a escala de fermentação do microrganismo. Como o período em que a bactéria apresentou maior fitotoxicidade foi entre 11 e 17 dias, a fermentação em maior escala foi realizada em um tempo intermediário de 15 dias, para garantir uma concentração máxima da fitotoxinas para a etapa posterior de isolamento e caracterização estrutural do composto ativo.

\section{5 - Fracionamento do extrato bruto EMB5B e identificação do princípio ativo}

A pós a otimização do período de fermentação para a produção máxima de metabólitos com atividade fitotóxica através do bioensaio com L. minor a escala de fermentação em meio líquido foi aumentada para $1 \mathrm{~L}$. Para esta fermentação, empregou-se Erlenmeyers de $1 \mathrm{~L}$ contendo $250 \mathrm{ml}$ (1/ 4) de meio de cultura BD.

A bactéria EMB5B foi fermentada em meio BD, por 15 dias, a $28^{\circ} \mathrm{C}$ e $130 \mathrm{rpm}$. A pós o período de incubação, o meio foi extraído com acetato de etila, produzindo 
uma massa total de $210 \mathrm{mg}$ do extrato bruto.

A partir do fracionamento desse extrato foram obtidas 86 frações, as quais foram agrupadas em cinco frações principais baseado nas semelhanças dos perfis obtidos por CCD. Em seguida, estas foram secas em rota-evaporador sob pressão reduzida.

Essas cinco frações foram submetidas a uma nova bateria de bioensaios. De acordo com o potencial de fitotoxicidade apresentado no bioensaio com Lemna minor, foi identificada uma fração ativa, F1 (Tabela 7).

Tabela 7. Fracionamento do extrato EMB5B e bioensaio de fitotoxicidade

\begin{tabular}{ccc}
\hline Fração & Massa $(\mathbf{m g})$ & Atividade biológica \\
\hline Fração 1 & $\mathbf{8}$ & +++ \\
Fração 2 & 3 & $-\ldots$ \\
Fração 3 & 3 & $-\ldots$ \\
Fração 4 & 40 & $-\ldots$ \\
Fração 5 & 59 & $-\ldots$ \\
\hline
\end{tabular}

A Figura 24 apresenta o resultado do teste de fitotoxicidade para as cinco frações. 


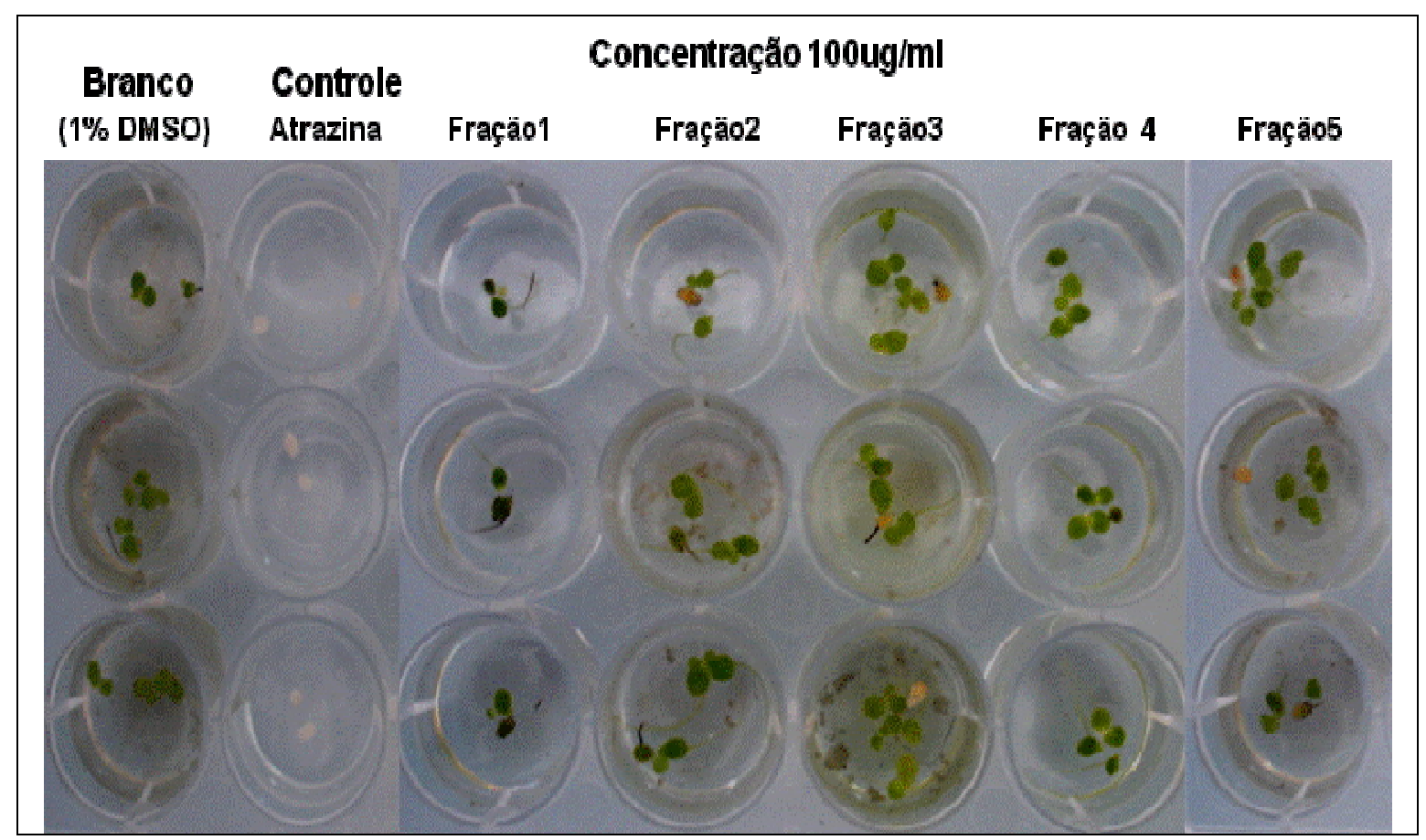

Figura 24. Ensaio de fitotoxicidade das frações cromatográficas F1, F2, F3, F4 e F5 do extrato bactéria EMB5B-15dias com L. minor.

Como observado na Figura 24, em relação ao branco (meio + DMSO 1\%), as folhas de L.minor se multiplicaram e permaneceram visualmente sadias enquanto que o controle (atrazina, coluna 2) provocou inibição do crescimento e necrose das pétalas. Em relação ao branco, as frações F2, F3, F4 e F5 provocaram necrose de algumas pétalas, mas esse efeito não foi observado em todos os poços, portanto concluímos que essas frações não apresentaram atividade fitotóxica pronunciada. $\mathrm{Na}$ terceira coluna, onde foi adicionada a fração $\mathrm{F} 1$, pode ser constatada a inibição completa da multiplicação das folhas da planta, uma vez que o ensaio foi inicial mente realizado com duas pétalas de L. minor agregadas, e após sete dias esse número permaneceu constante, havendo assim uma inibição completa da multiplicação das folhas. A pesar da fração não ter provocado necrose na planta, em 
relação à inibição de crescimento, o efeito causado por essa fração foi o mesmo observado para o controle, a atrazina.

A Figura 25 apresenta o cromatograma LC-UV da Fração 1. Podemos observar a presença de um pico com tempo de retenção 17,5 minutos. Esta análise possi bilitou identificar desse composto no cromatograma do extrato bruto EMB5B (Figura 23, pág 52).

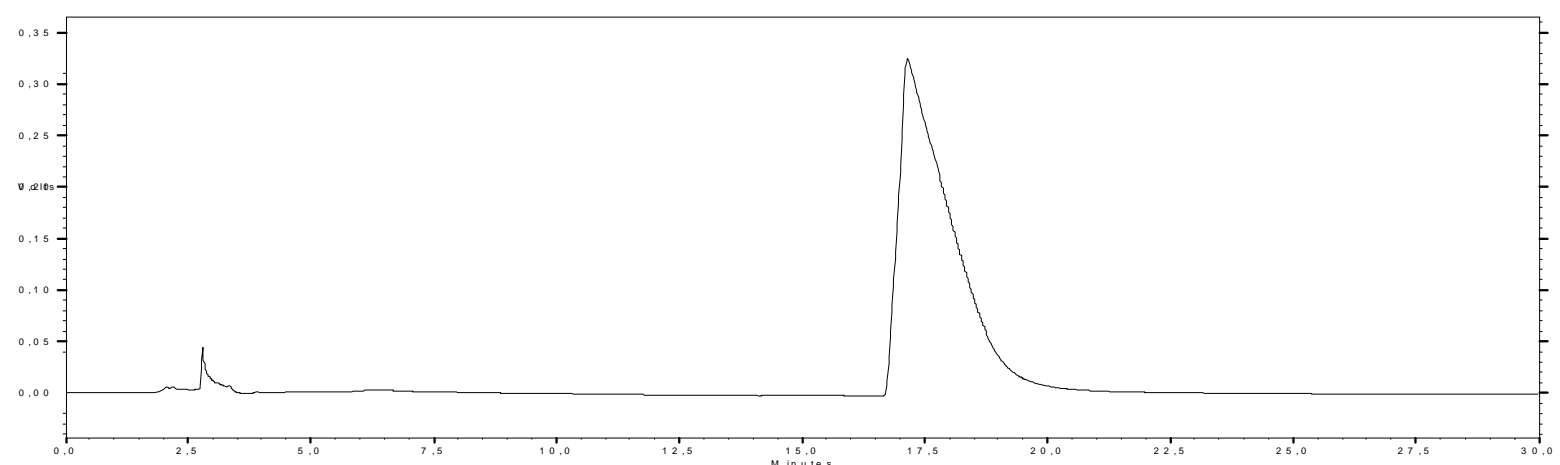

Figura 25. LC-UV da fração ativa, fase móvel $\mathrm{H}_{2} \mathrm{O} / \mathrm{ACN} 10 \%$, modo isocrático e fluxo $1 \mathrm{ml} / \mathrm{min}$. Coluna C18 $(250 \times 4,60 \mathrm{~mm}), \lambda=215 \mathrm{~nm}$.

O espectro de massas da fração 1 esta apresentado na Figura 26, possibilitou determinar a massa molecular do composto ativo. 


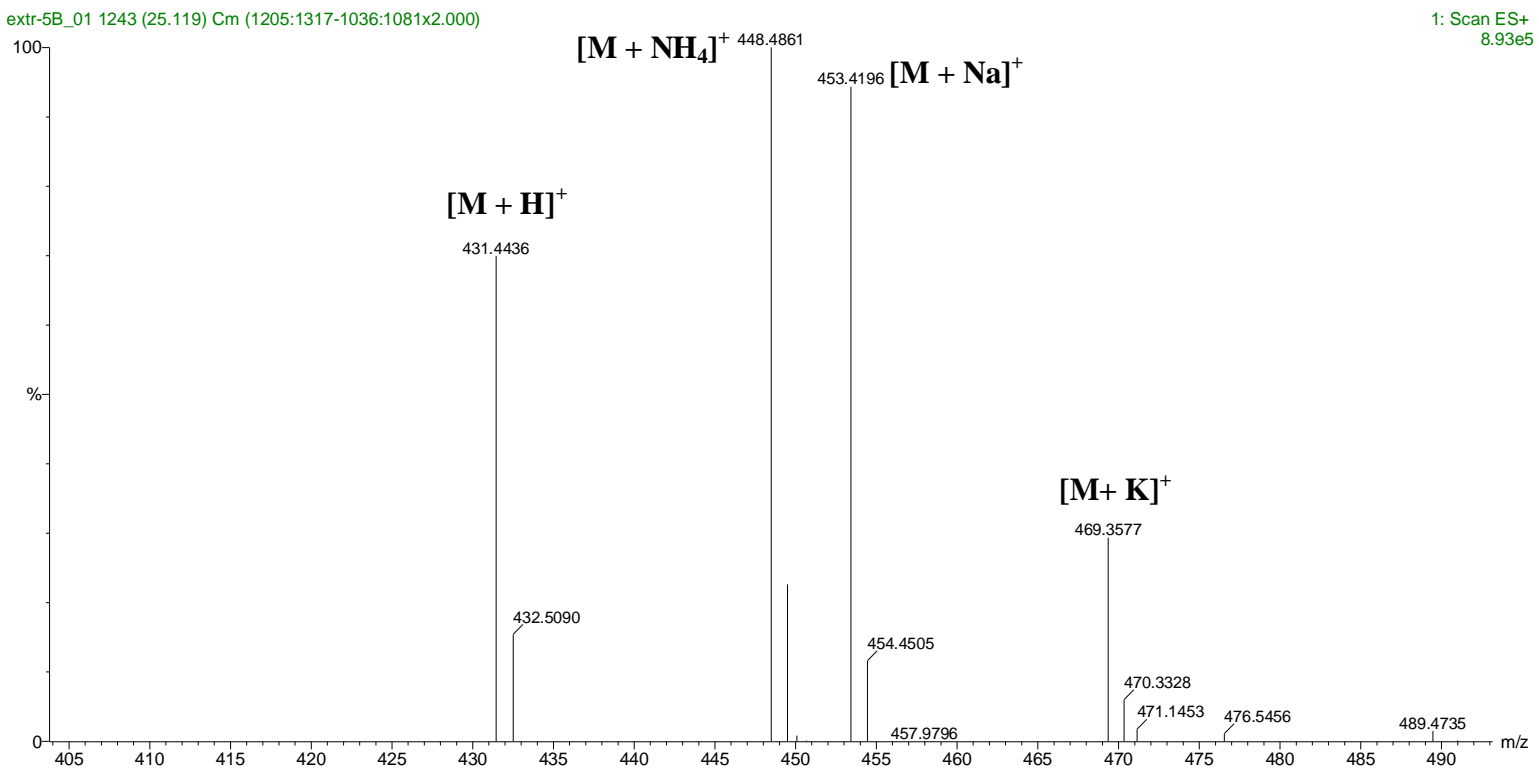

Figura 26. Espectro de massas referente à fração 1 no modo ESI ${ }^{+}$.

Nesse espectro, é observado um “cluster" de sinais de m/z 431, m/z 448, m/z 453 e m/z 469. Esses sinais confirmam que o princípio ativo possui uma massa molecular de $430 \mathrm{Da}$. Os sinais observados no espectro de ESI + foram caracterizados como m/z $431[\mathrm{M}+\mathrm{H}]^{+}, \mathrm{m} / \mathrm{z} 448\left[\mathrm{M}+\mathrm{NH}_{4}\right]^{+}, \mathrm{m} / \mathrm{z} 453[\mathrm{M}+\mathrm{Na}]+e \mathrm{~m} / \mathrm{z} 469[\mathrm{M}+\mathrm{K}]^{+}$. A grande abundância relativa desses adutos no espectro sugere que esse composto possui uma grande afinidade por cátions.

Também foi realizada análise por LC-MS do extrato EMB5B. A Figura 27b, apresenta o cromatograma de LC-MS obtido do extrato bruto. A Figura 27a apresenta o cromatograma proveniente da extração do íon de $\mathrm{m} / \mathrm{z} 453[\mathrm{M}+\mathrm{Na}]^{+}$, referente à molécula do princípio ativo sodiada. 


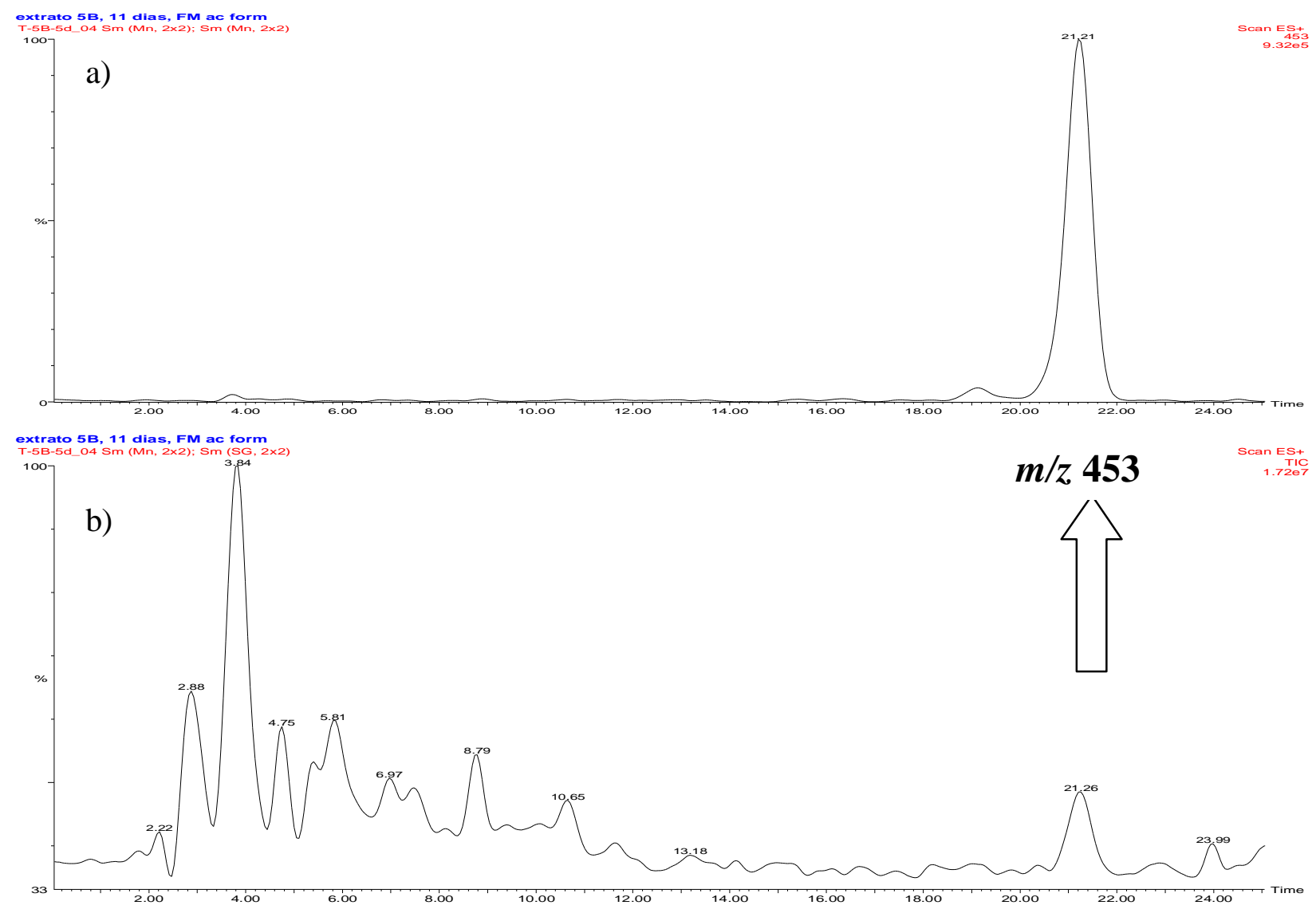

Figura 27. (a) extração do íon $\mathrm{m} / \mathrm{z} 453$ e (b) cromatograma de LC-MS do extrato EMB5B-11dias (ESI+, potencial do cone $50 \mathrm{~V}$ ). Fase móvel: $\mathrm{H}_{2} \mathrm{O} / \mathrm{ACN} 10 \%$ e ácido fórmico $0,1 \%$, coluna $\mathrm{C} 18$ $(4.60 \times 100 \mathrm{~mm})$ e fluxo $0,3 \mathrm{ml} / \mathrm{min}$.

Os sinais de m/z 431 e m/z 453 foram submetidos a um estudo de fragmentação induzida por colisão (CID), Figura 28 e Figura 30, com a finalidade de obter informações estruturais do princípio ativo. 


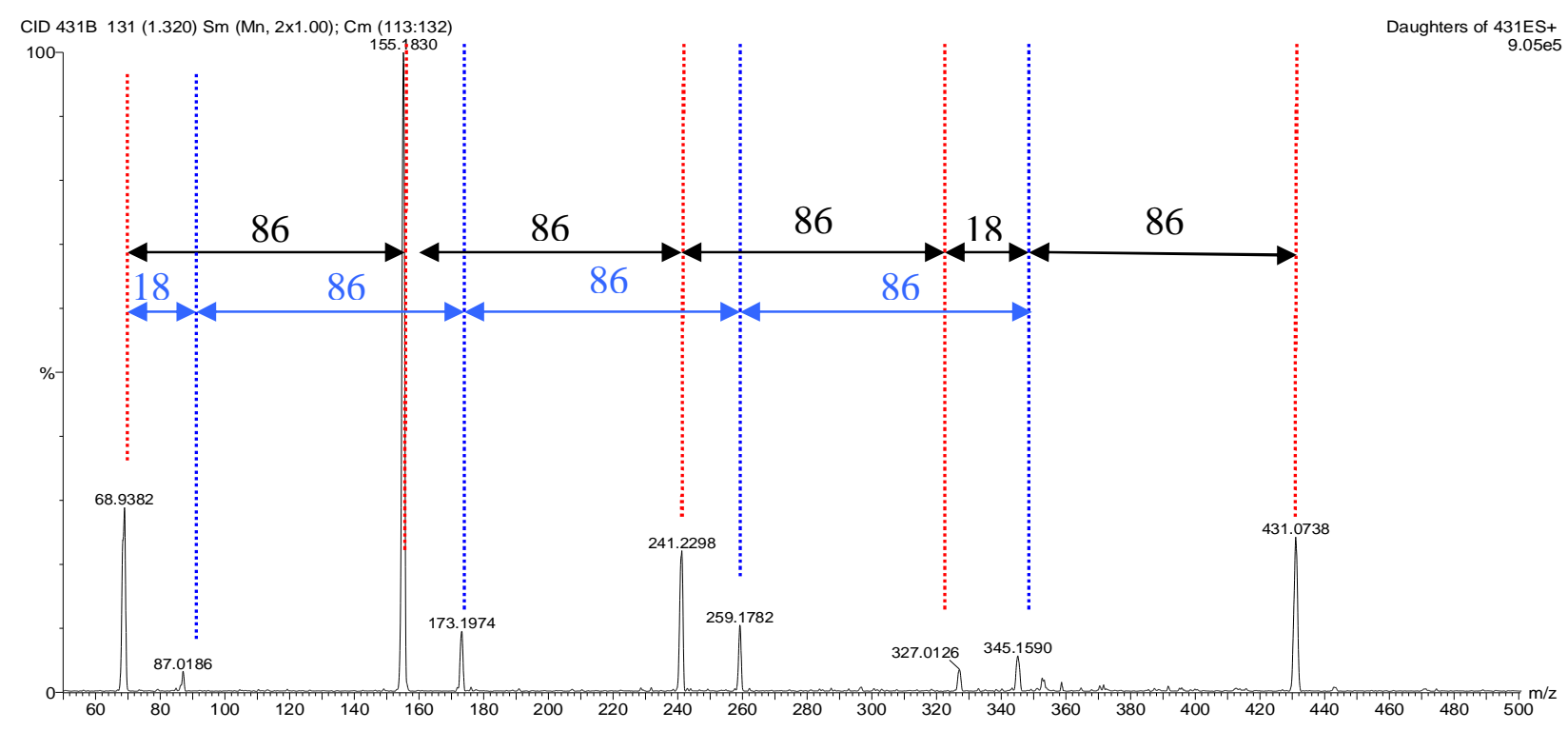

Figura 28. Espectro de ESI-MS/MS do íon de $m / z 431[\mathrm{M}+\mathrm{H}]^{+}$no modo $\mathrm{ESI}^{+}$, potencial do cone $30 \mathrm{~V}$ e energia de colisão $15 \mathrm{eV}$.

O espectro de massas da Figura 28 mostra que a fragmentação do composto bioativo protonado (m/z 431), pode ocorrer por duas vias diferentes. A primeira ocorre por uma perda de $86 \mathrm{Da}$, seguida de $\mathrm{H}_{2} \mathrm{O}(18 \mathrm{Da})$ e três perdas seqüenciais de $86 \mathrm{Da}$, que originam os íons filhos de m/z 345, m/z 327, m/z 241, m/z 155, m/z 69 (setas pretas). Na segunda, (setas azuis) ocorrem quatro perdas em série de $86 \mathrm{Da}$, seguida de uma perda de $\mathrm{H}_{2} \mathrm{O}$, formando os íons filhos m/z 345, m/z 259, m/z 173, m/z 87, m/z 69.

Com base no espectro de MS/ MS foi proposto um caminho de fragmentação para o principio ativo dem/z 431 (Figura 29). 

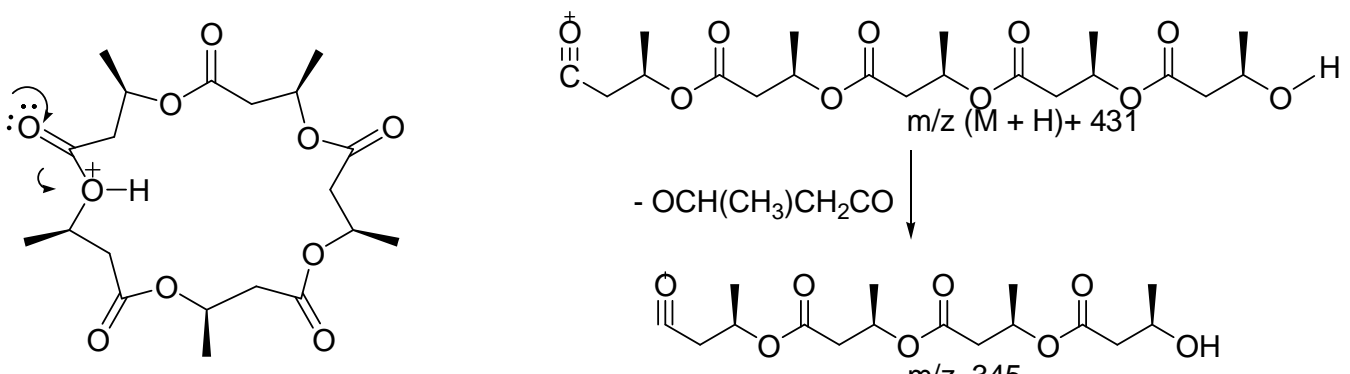

$\mathrm{C} 2 \mathrm{OH} 31 \mathrm{O} 10+$

$\mathrm{m} / \mathrm{z}(\mathrm{M}+\mathrm{H})+431,1912$

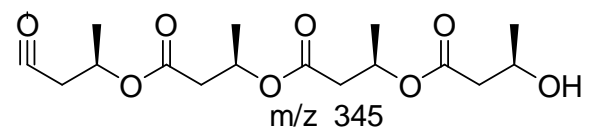

- $\mathrm{OCH}\left(\mathrm{CH}_{3}\right) \mathrm{CH}_{2} \mathrm{CO}$

$-\mathrm{H}_{2} \mathrm{O}$
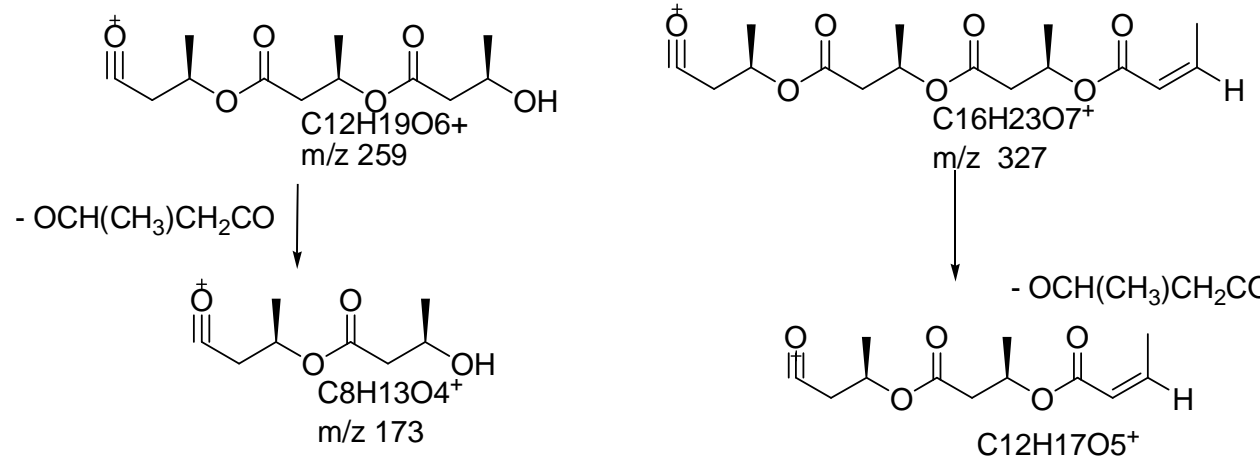

$\mathrm{m} / \mathrm{z} 327$
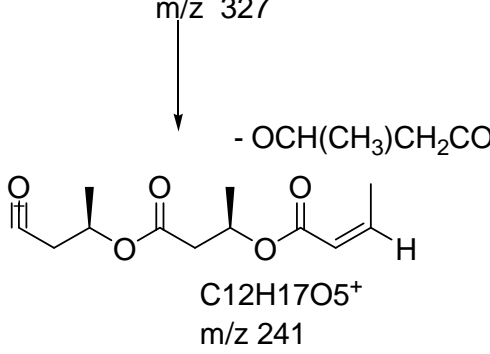

- $\mathrm{OCH}\left(\mathrm{CH}_{3}\right) \mathrm{CH}_{2} \mathrm{CO}$
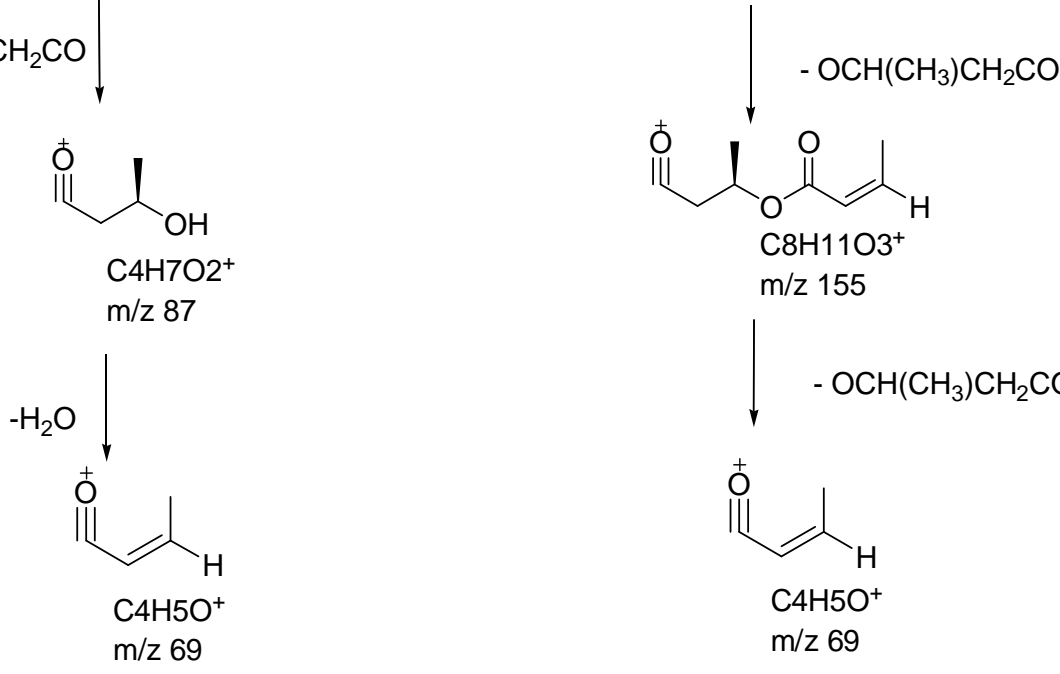

$\mathrm{C} 8 \mathrm{H} 11 \mathrm{O}^{+}$

$\mathrm{m} / \mathrm{z} 155$

- $\mathrm{OCH}\left(\mathrm{CH}_{3}\right) \mathrm{CH}_{2} \mathrm{CO}$

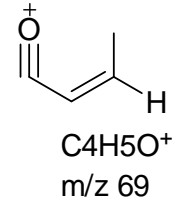

Figura 29. Caminho de fragmentação do composto de $m / z 431$. 
O espectro de ESI-MS/ MS do composto ativo sodiado de $\mathrm{m} / \mathrm{z} 453$ [M + Na] ${ }^{+}$ apresentou um padrão de fragmentação semelhante a do composto protonado (Figura 30). Porém, o caminho de fragmentação ocorre apenas através das quatro perdas seqüenciais de fragmentos neutros com $86 \mathrm{Da}$, que geraram os íons filhos m/z 367, m/z 281, m/z 195 e m/z 109.

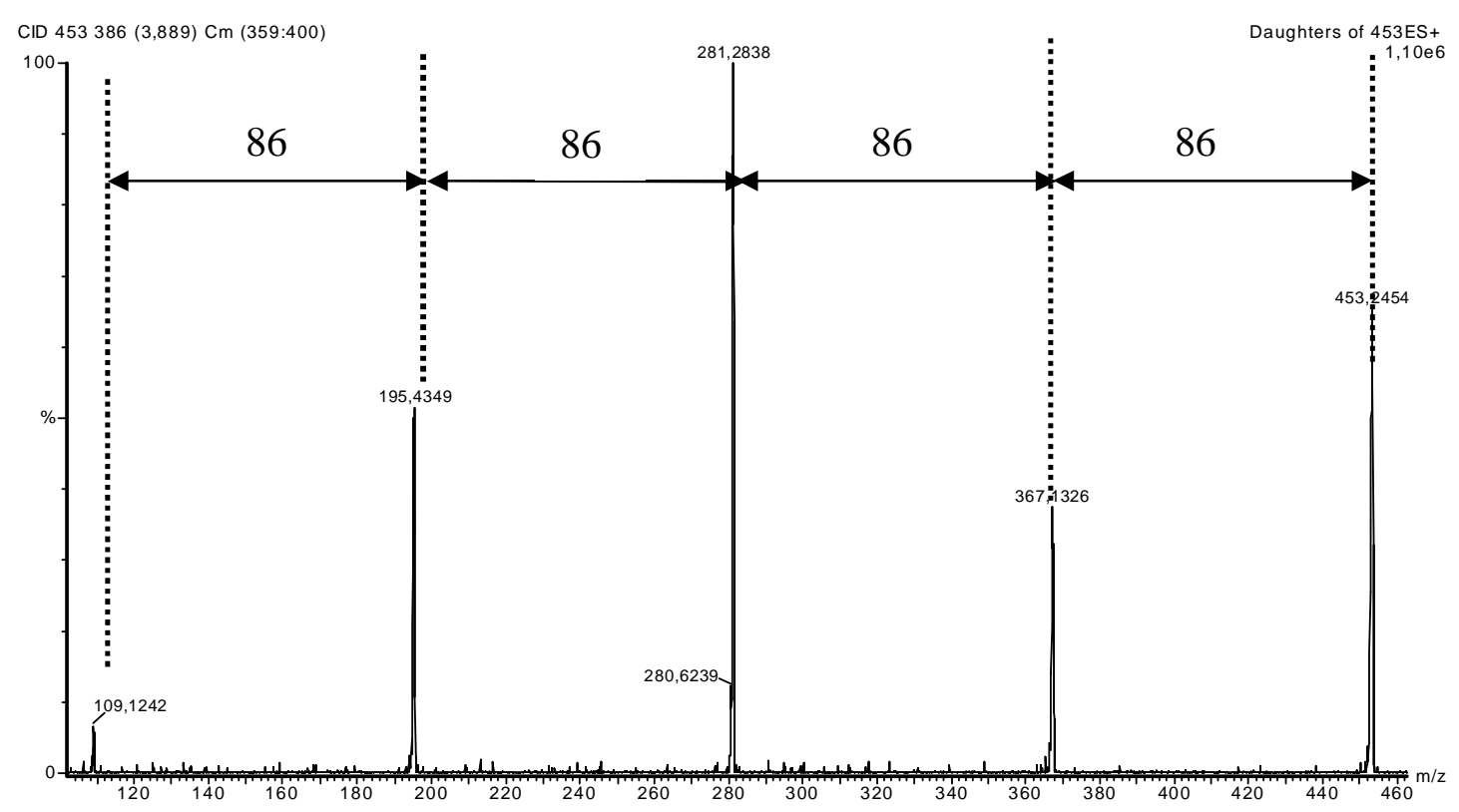

Figura 30. Espectro de ESI-MS/MS do composto de $m / z 453[\mathrm{M}+\mathrm{Na}]^{+}$no modo $\mathrm{ESI}^{+}$, potencial do cone $45 \mathrm{~V}$ e energia de colisão $25 \mathrm{eV}$.

Os espectros de massas obtidos até aqui apontaram alguns aspectos importantes que nos levaram a conclusões preliminares a respeito da estrutura do composto.

Primeiramente, a molécula referente ao composto ativo foi ionizada no modo positivo e não mostrou nenhuma ionização no modo negativo. Como foi dito 
anteriormente, substâncias que apresentam grupamentos básicos, principalmente aminas, amidas e ésteres, normalmente são analisadas nesse modo.

Um outro aspecto importante é a presença dos adutos metálicos no espectro de ESI-MS o que indica que o composto ativo possui grande afinidade por cátions. Este fato sugere que esta molécula pode ser uma substância orgânica contendo átomos como oxigênio, nitrogênio, enxofre, entre outros, que possuem elétrons livres que funcionam como sítios de complexação com metais. Os íons que possuem carga positiva são atraídos pelos pares eletrônicos livres, se coordenando ao composto devido à ação de forças el etrostáticas.

Baseados nas análises dos espectros sugerimos que esses heteroátomos podem ser átomos de oxigênio ou números pares de átomos de nitrogênio. Como o composto de $\mathrm{m} / \mathrm{z} 431[\mathrm{M}+\mathrm{H}]^{+}$fragmenta-se perdendo água, concluímos que a molécula possui oxigênio em sua estrutura.

Outro aspecto interessante refere-se ao perfil de fragmentação observado para os íons de $\mathrm{m} / \mathrm{z}[\mathrm{M}+\mathrm{H}]^{+}$e $\mathrm{m} / \mathrm{z}[\mathrm{M}+\mathrm{Na}]^{+}$. As perdas sequenciais de fragmentos que possuem a mesma unidade de massa indicaram que a molécula possui uma estrutura "polimérica" e que a fragmentação ocorre mediante perdas de monômeros cujas massas são de 86 Da.

N ossas observações foram confirmadas através da comparação das análises espectroscópicas e espectrométricas para o composto ativo com dados descritos na literatura.

Em 1988 quando o químico Seebach e colaboradores tentavam sintetizar um 
composto derivado dos antibióticos naturais pirenoforina, vermiculina e el aiofilina, a partir da reação de macrolactonização do áci do R-3- hidroxibutanóico sob condições de Yamagushi,65 obteve como produto uma mistura equimolar (1:1:1) de três oligômeros cíclicos, que foram identificados como um trímero, um pentólido e um hexólido.66

Os dados de RMN'H e ESI-MS/MS, obtidos para o composto fitotóxico isolado da bactéria EMB5B foram idênticos aos dados obtidos para o pentólido cíclico. A análise dos dados obtidos bem como a comparação com esses dados da literatura apresentados permitiu determinar a estrutura do composto ativo como sendo um pentâmero cíclico do ácido 3-hidroxibutánoico (Figura 31).

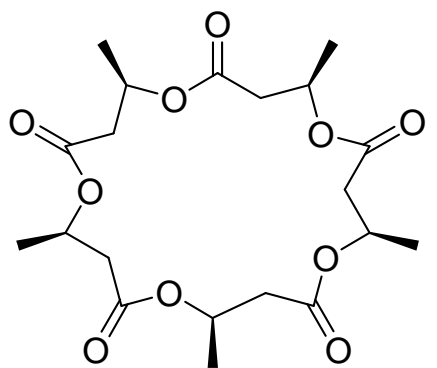

Figura 31. Estrutura do pentâmero fitotóxico

Além da espectrometria de massas, a estrutura do composto ativo também foi confirmada por Infravermel ho, RMN ${ }^{1 H}$, RMN ${ }^{13} \mathrm{C}, \mathrm{HMQC}$ e HMBC. Os espectros de $\mathrm{RMN}^{1} \mathrm{H}$, e $\mathrm{RMN}^{13} \mathrm{C}$ apresentados nas Figuras 33 e 34, respectivamente, revelaram grupos de sinais característicos de polihidroxibutiratos. ${ }^{67,68}$

A técnica de espectroscopia de infravermelho foi usada por Karanth e colaboradores para monitorar a produção de PHBs por uma grande variedade de 
microrganismos, através identificação da banda do éster carboxílico em 1724 cm-1 nas amostras, como banda característica de PHB.69

O espectro de infravermelho do pentólido puro está apresentado na Figura 32. Pode ser observada uma banda forte em $1728 \mathrm{~cm}^{-1}$, que corresponde ao estiramento dos grupo $C=0$ eduas bandas intensas em $1303 \mathrm{~cm}^{-1}$ e $1118 \mathrm{~cm}^{-1}$ que correspondem aos estiramentos do grupo e C-O. O espectro também apresentou as bandas com intensidade média em $2993 \mathrm{~cm}^{-1}, 2963 \mathrm{~cm}^{-1}, 2921 \mathrm{~cm}^{-1}$ correspondente a deformação axial das ligações $\mathrm{C}-\mathrm{H}$ sp33. 


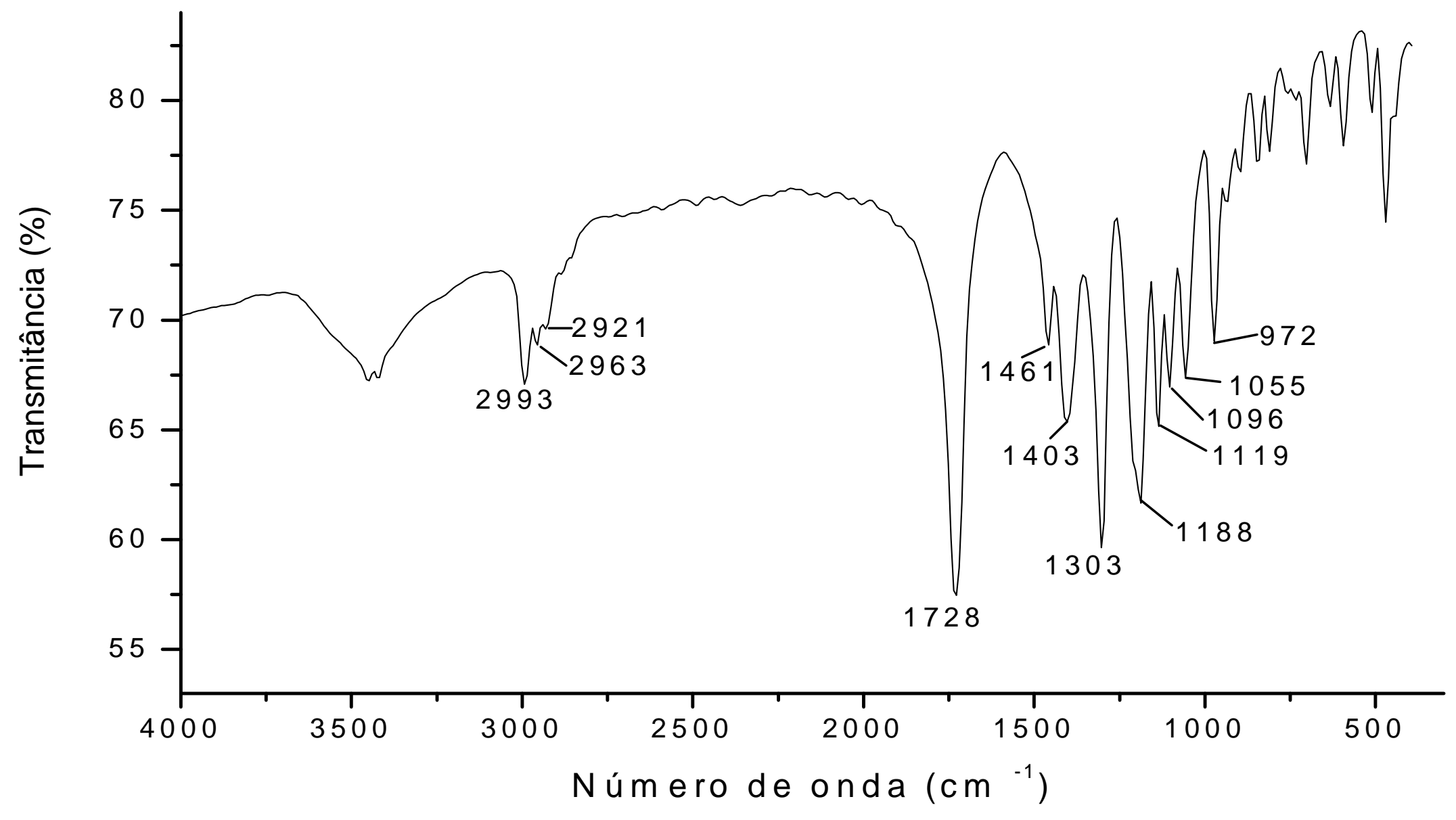

Figura 32. Espectro de Infravermelho da Fração 1. 
Para o espectro de RMN ${ }^{1} \mathrm{H}$ (Figura 33), o dubleto $\left(J^{3}=6,5 \mathrm{~Hz}\right)$ em 1,30 ppm foi atribuído ao grupo metílico; os sinais em 2,54 ppm correspondem ao par de prótons diasterostópicos adjacentes a um átomo de carbono assimétrico ligado a um único próton e o multipleto em 5,25 ppm, corresponde ao próton do carbono assimétrico, adjacente ao grupo metílico e ao par de prótons diasterostópicos. Os dados de RMN ${ }^{13} \mathrm{C}$ da substância (Figura 34) apresentaram sinais em 20,1 ppm correspondentes ao carbono metílico, 41,3 ppm referente ao carbono metilênico, 67,89 ppm foi atribuído ao carbono ligado ao oxigênio e o sinal correspondente a carbonila do éster foi identificado em 169,76 ppm. 
$\stackrel{2}{2}$

in

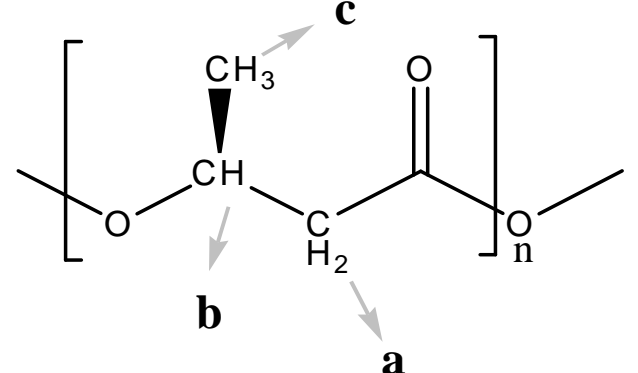

a

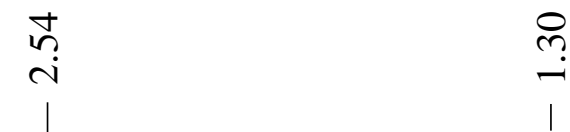

$\underset{-1}{1}$

i̦

Tion

b

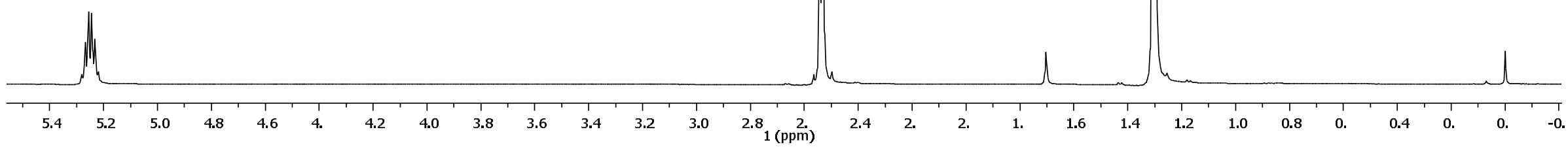

Figura 33. Espectro de RMN1H do composto bioativo da bactéria , obtido em 500MHZ ( $\left.\mathrm{CDCl}_{3}-\mathrm{TMS}\right)$. 

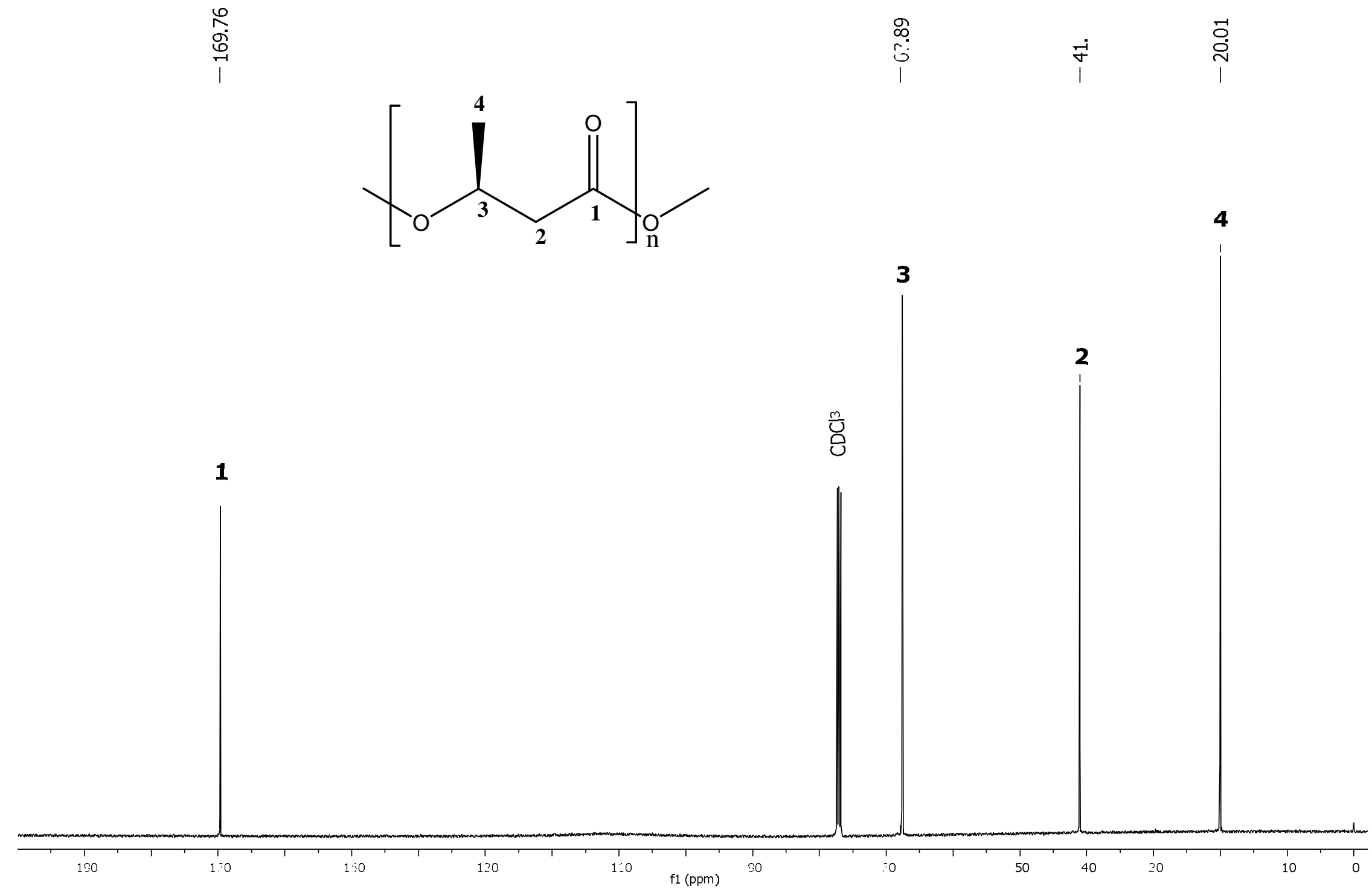

Figura 34. Espectro de RMN13C do composto bioativo da bactéria EMB5B, obtido em $400 \mathrm{MHz}$ (CDCl ${ }_{3}-\mathrm{TMS}$ ). 
Para o pentólido, também foram obtidos os mapas de contorno de HMQC (Figura 35) e HMBC (Figura 36). As análises desses espectros permitiram confirmar a estrutura proposta pela determinação das correlações entre carbonos e hidrogênios. Os espectros de HMQC, o qual apresenta correlações de hidrogênios ligados a carbonos (1) C-H) apresentou os seguintes dados:

- carbono em $\delta$ 20,01 apresenta correl ação com o hidrogênio em $\delta$ 1,30.

- carbono em $\delta ~ 41,03$ apresenta correl ação com o hidrogênio em $\delta$ 2,54.

- carbono em $\delta$ 67,89 apresenta correl ação com o hidrogênio em $\delta$ 5,25.

O espectro de $\mathrm{HMBC}{ }^{1} \mathrm{H}-{ }^{13} \mathrm{C}$, que correlaciona hidrogênios ligados a carbonos através de 2 ou 3 ligações $\left({ }^{2} \int_{C-H},{ }^{3}{ }_{C-H}\right)$ apresentou os seguintes resultados:

- hidrogênio em $\delta 1.30(\mathrm{H}-\mathrm{C})$ se correlaciona com carbonos em $\delta 67,89\left({ }^{2} \mathrm{~J}\right) ; \delta 41,03\left({ }^{3} \mathrm{~J}\right)$ e $\delta 169,76\left({ }^{4} \mathrm{~J}\right)$.

- hidrogênio em $\delta 2.54(\mathrm{H}-\mathrm{a}) \mathrm{se}$ correlaciona com carbonos em $\delta 67,89\left({ }^{2} J\right) ; \delta 169,76\left({ }^{2} J\right)$ e $\delta 20,01\left({ }^{3} J\right)$.

- hidrogênio em $\delta 5.25(\mathrm{H}-\mathrm{b})$ se correlaciona com carbonos em $\delta 41,03\left({ }^{2} J\right) ; \delta 20,01\left({ }^{2} J\right) \varepsilon \delta 169,76\left({ }^{3} J\right)$. 


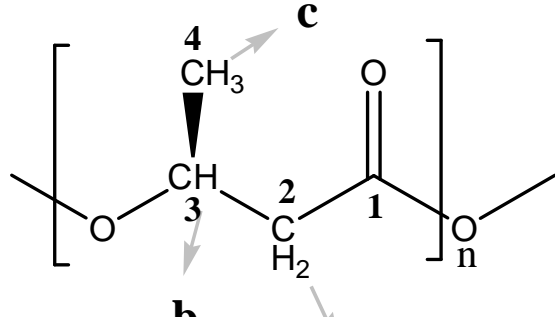

b
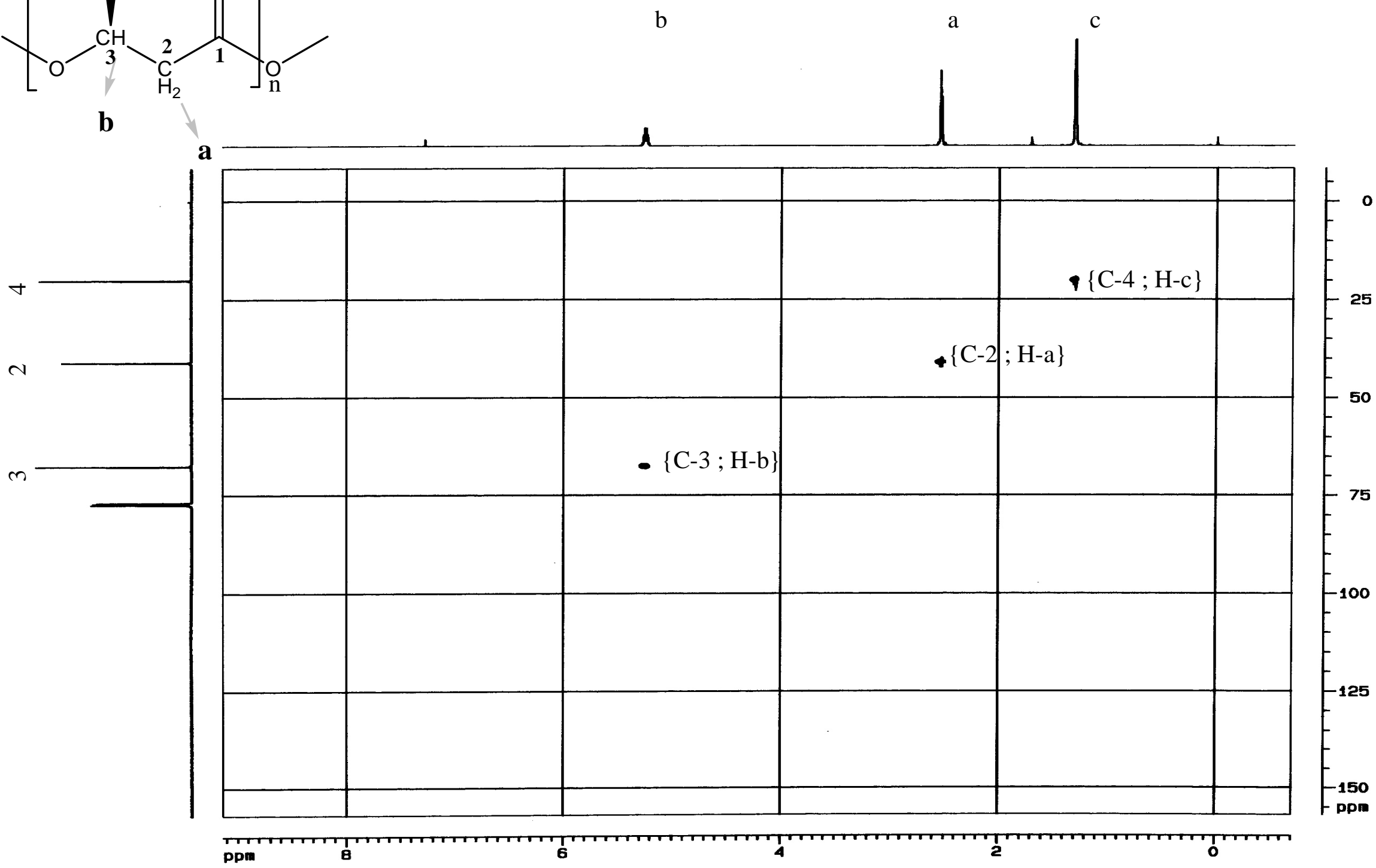

Figura 35. Espectro de HMQC do composto bioativo da bactéria EMB5B, obtido em $400 \mathrm{MHz}$.(CDCl ${ }_{3}, \mathrm{TMS}_{\text {) }}$. 


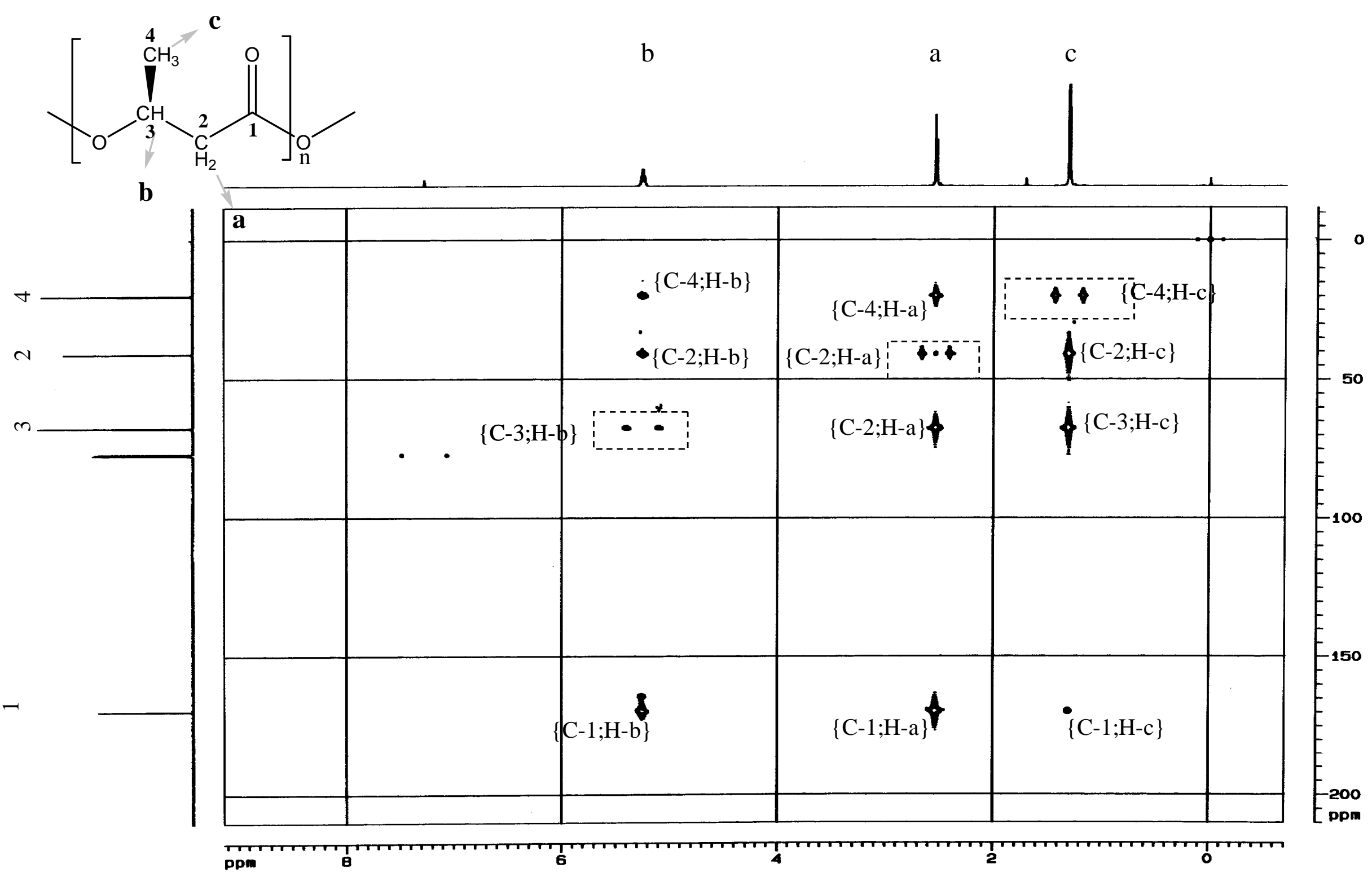

Figura 36. Espectro de HMBC do composto bioativo da bactéria EMB5B, obtido em 500MHz. (CDCl 3 , TMS) 
Fitotoxinas podem apresentar diferentes modos de ação. ${ }^{70} \mathrm{O}$ modo de ação do composto ativo não foi estudado neste projeto, todavia, segundo Duke e colaboradores,71 uma análise detalhada da estrutura química da molécula pode oferecer alguma indicação relacionada a seu modo de ação.

Uma característica estrutural que pode estar relacionada com a toxicidade do composto é a capacidade de quelar com metais. Os agentes complexantes são também chamados de ionóforos, que significa transportadores (foros) de íons. Substâncias como a ftalocianina foi isolada, sintetizadas e estudadas como potentes antibióticos, devido sua propriedade de formar complexos com íons metálicos (Figura 37).72

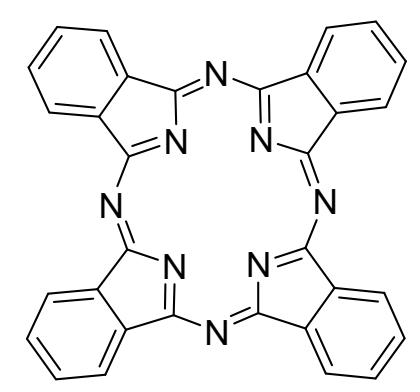

Figura 37. Antibiótico ftalocianina.

Foi demonstrado que vários oligômeros cíclicos, derivados do ácido (R)-3hidroxibutírico, dentre eles o pentólido o qual foi isolado neste estudo, além de um trímero e outros derivados alifáticos, também funcionam como ionóforos. O trabal ho publicado mostrou que essas moléculas são capazes de transportar metais alcalinos como $\mathrm{Li}^{+} \mathrm{e} \mathrm{Cs}^{+}$e metais alcalinos terrosos do $\mathrm{Mg}^{2+}$ e $\mathrm{Ba}^{2+}$ através de uma membrana 
composta por uma fase orgânica de $\mathrm{CH}_{2} \mathrm{Cl}_{2}{ }^{73}$ As propriedades ionofóricas dos oligômeros investigados derivados do ácido (R)-3-hidroxibutírico são compatíveis com as propriedades biológicas observadas para os PHB como componentes de canais iônicos de membranas celulares. ${ }^{74}$

Os ionóforos em geral são conhecidos como moléculas cujos esqueletos são formados de diversas estruturas que contêm heteroátomos localizados estrategicamente no espaço.

Essas moléculas são capazes de assumir conformações críticas nas quais os heteroátomos estão localizados em uma cavidade de um anel, por exemplo. Nessa conformação um cátion pode se alojar mais facilmente. Os oxigênios ligantes constituem-se de vários grupos funcionais como éteres, al coóis, carboxilas e amidas. Os oxigênios ligantes neutros ligam-se aos cátions via interação íon-dipolo, anal ogamente a solvatação de íons em solventes com constantes dielétricas altas.75

Foi realizada uma otimização conformacional do pentólido empregando mecânica molecular método MM2 utilizando o Software ChemDraw 8.0. Para a conformação de mais baixa energia adotada pelo pentólido, os quatro oxigênios carbonílicos estão local izados no mesmo lado do plano da molécula e o outro átomo, do lado oposto. Estudo cristalográfico do pentólido já foi descrito na literatura, confirmando a estrutura proposta. 76 Como pode ser observado na Figura 38, nesta conformação, os oxigênios das carbonilas dos ésteres podem servir como sítios de complexação para os cátions. A grande afinidade do pentólido por cátions pode ser constatada no espectro de massas da fração ativa F1 (Figura 26, pg. 57). Pode-se 
observar a alta abundância dos sinais referentes ao composto ativo cationizado com sódio, potássio e amônio.
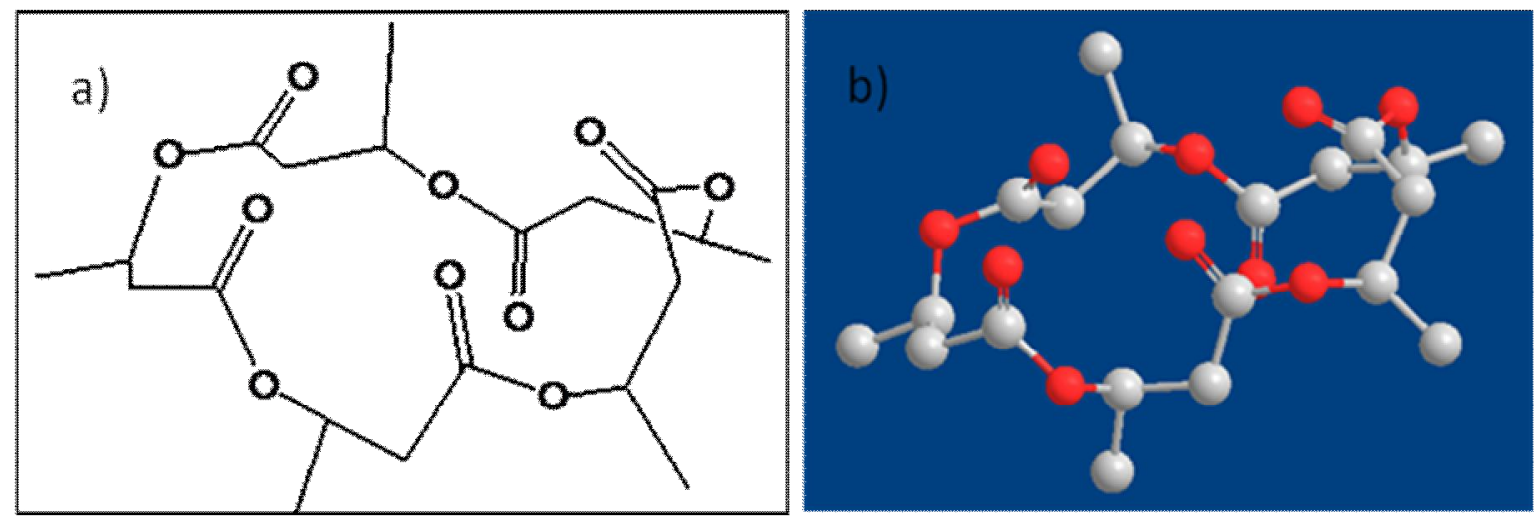

Figura 38. Conformação otimizada (MM2) do pentólido fitotóxico.

Uma vez que esses compostos são capazes de quelar com metais e atravessar membranas, devido às propriedades discutidas anteriormente, o seu modo de ação pode estar relacionado com a capacidade de ocasionar alterações no gradiente iônico celular.

Outro aspecto importante em relação à estrutura do composto ativo é que pode servir como modelo para a síntese de novos compostos com atividade fitotóxica.

Substâncias com estruturas análogas também apresentam bioatividade. Os compostos apresentados na Figura 39 são fitotoxinas que possuem estruturas análogas ao pentólido, ou seja, são macrolactonas. Lactonas produzidas pelo fungo Cladosporium tenuissimum, são responsáveis por inibir o crescimento de plantas. ${ }^{77}$ 
<smiles>[R7]C1([R2])CCCCC[C@@H](C)OC(=O)/C=C/[C@@H]1O</smiles>

Cladosporide $\mathrm{A} \quad \mathrm{R}_{1}=\mathrm{H} \mathrm{R} \mathrm{R}_{2}=\mathrm{OH}$ Cladosporide $\mathrm{C} \quad \mathrm{R}_{1}=\mathrm{OH} \mathrm{R} \mathrm{R}_{2}=\mathrm{H}$<smiles>C[C@H]1CCCC[C@@H](O)[C@@H](O)/C=C\C(=O)C(=O)O1</smiles>

Cladosporide B

Figura 39. Macrolactonas fitotóxicas produzidas pelo fungo Cladosporium tenuissium.

O fungo Colletrotrichum gloeosporioides é conhecido por causar danos em plantações de morango e uva. Ele produz uma fitotoxina, a gloeosporona cuja estrutura também é semelhante a do pentólido fitotóxico (Figura 40). ${ }^{78}$

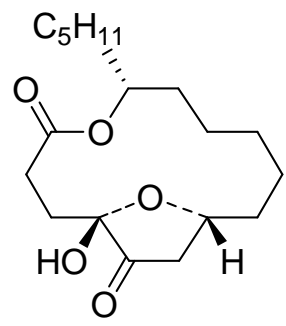

Gleosporona<smiles>CC(CC(=O)O)OC(=O)/C=C/CC(C)OC(=O)CCC(=O)O</smiles>

Colletoketol<smiles>C=C(CC(O)CCC(=O)OC(C)C)[C@H](C)OC(=O)/C=C/C[C@@H](C)O</smiles>

Colletallol

Figura 40. Macrolactonas produzidas pelo fungo Colletrotrichum gloeosporioides

\section{6 - Monitoramento da produção do composto ativo por MRM}

Resultados anteriores mostraram que a produção do metabólito bioativo pela bactéria 5B é dependente do tempo de fermentação. Em função desse fato achamos apropriado fazer um estudo mais detalhado para determinar o período em que a produção do metabólito bioativo é máxima. Esse estudo foi realizado por LC- 
MS/ MS, empregando os dados adquiridos no modo MRM (Monitoramento de Reações Múltiplas). O objetivo de aplicar essa metodologia foi monitorar a produção do composto fitotóxico de uma forma rápida, robusta, sensível e seletiva sem a necessidade de isolar o analito ou mesmo saber sua estrutura.

Neste modo de varredura, o íon precursor de interesse é selecionado no quadrupolo Q1, fragmentado em Q2 com gás de colisão, e um único íon fragmento é selecionado em Q3, como mostra a Figura 41.

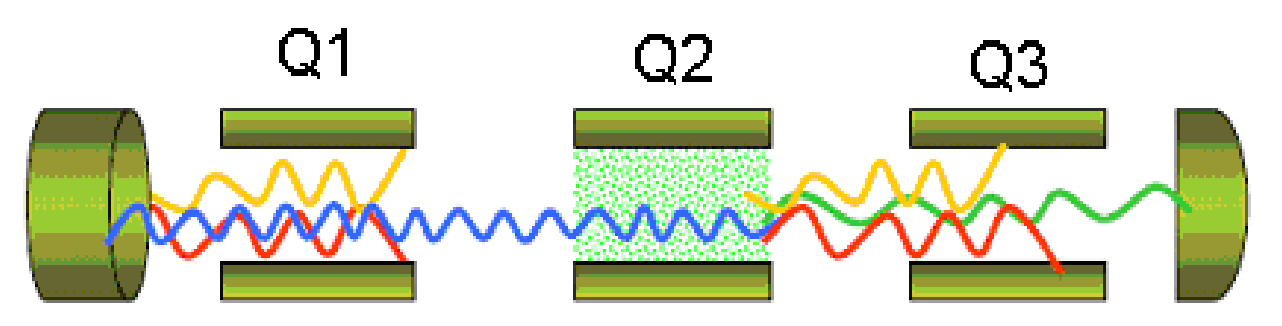

\section{Fonte}

\section{Detector}

Figura 41. Esquema do experimento de MRM (Monitoramento de Reações Múltiplas).

O cromatograma obtido neste modo de analise é muito mais simples, contendo apenas um pico cromatográfico referente ao canal selecionado pelo íon precursor e seu respectivo fragmento. Portanto, esse procedimento é ideal para a anál ise de compostos al vo em matrizes complexas.

A LC-MS/ MS possui a vantagem de ser método extremamente sensível e seletivo para a determinação simultânea de metabólitos em pequenas quantidades de amostras que contêm concentrações baixas de analitos. Estudos anteriores de 
produtos naturais empregaram o método SIR (Single Íon Recording) para o estudo de metabólitos secundários, mas esta metodologia apresenta al gumas desvantagens como o aparecimento de "falsos positivos" e a supressão iônica, o que é comum na análise de amostras biológicas.79

Para realizar o experimento, a bactéria foi cultivada em $25 \mathrm{ml}$ de meio BD. Esta cultura foi empregada como préinóculo. As culturas para análise foram fermentadas em 11 alíquotas de $25 \mathrm{ml}$ de meio BD, presentes em Erlenmeyers de 100 ml. Uma dessas alíquotas foi usada como branco e as outras foram inoculadas, com 1 ml do préinóculo, para garantir que todos os meios recebessem a mesma quantidade de células. $\mathrm{O}$ ensaio foi monitorado a cada dois dias, durante um período de 21 dias. Os extratos obtidos para cada ponto de análise foram diluídos em metanol para uma concentração final de $1000 \mu \mathrm{g} / \mathrm{ml}$.

A análise cromatográfica desses extratos foi realizada em uma coluna de fase reversa Polaris C18 $(5.0 \times 20 \mathrm{~mm}) 5 \mu$ Varian. A fase móvel foi uma mistura de $\mathrm{H}_{2} \mathrm{O} / \mathrm{ACN}$ (90:10) e de acetato de amônio $10 \mathrm{mM}$ e o fluxo foi de $0,2 \mathrm{ml} / \mathrm{min}$ no modo isocrático.

Os canais MRM foram selecionados com base nos espectros de fragmentação dos seus íons precursores. Assim, para o composto ativo, o íon precursor de m/z 431 foi selecionado no Q1, com uma voltagem do cone de $30 \mathrm{~V}$. Este íon foi dissociado com uma energia de colisão de 15 eV em Q2 com argônio. Os fragmentos foram analisados em Q3, onde o sinal de m/z 155 foi selecionado por apresentar maior intensidade relativa, nessas condições. Com o objetivo de confirmar a presença do 
composto ativo nos extratos, seu respectivo aduto sodiado também foi monitorado aplicando-se a mesma metodologia. A energia do cone foi de $45 \mathrm{~V}$ para a otimização do sinal de m/z 453. A energia de colisão foi de $25 \mathrm{eV}$, a qual apresentou o fragmento de m/z 281 como sendo o mais intenso.

A determinação da produção máxima do composto ativo foi realizada a partir do monitoramento dos canais referentes ao composto ativo protonado, e o mesmo composto cationizado com sódio para confirmar a presença do composto ativo no extrato bruto. Foram anal isados simultaneamente os canais m/z $431>155$ e $453>281$.

Podemos observar pelo LC-MS/ MS referente ao canal m/z $431>155$ obtido pelo modo MRM (Figura 42), a alta sel etividade para o canal selecionado, devido a presença de apenas um pico em $t_{R} 3,35 \mathrm{~min}$.

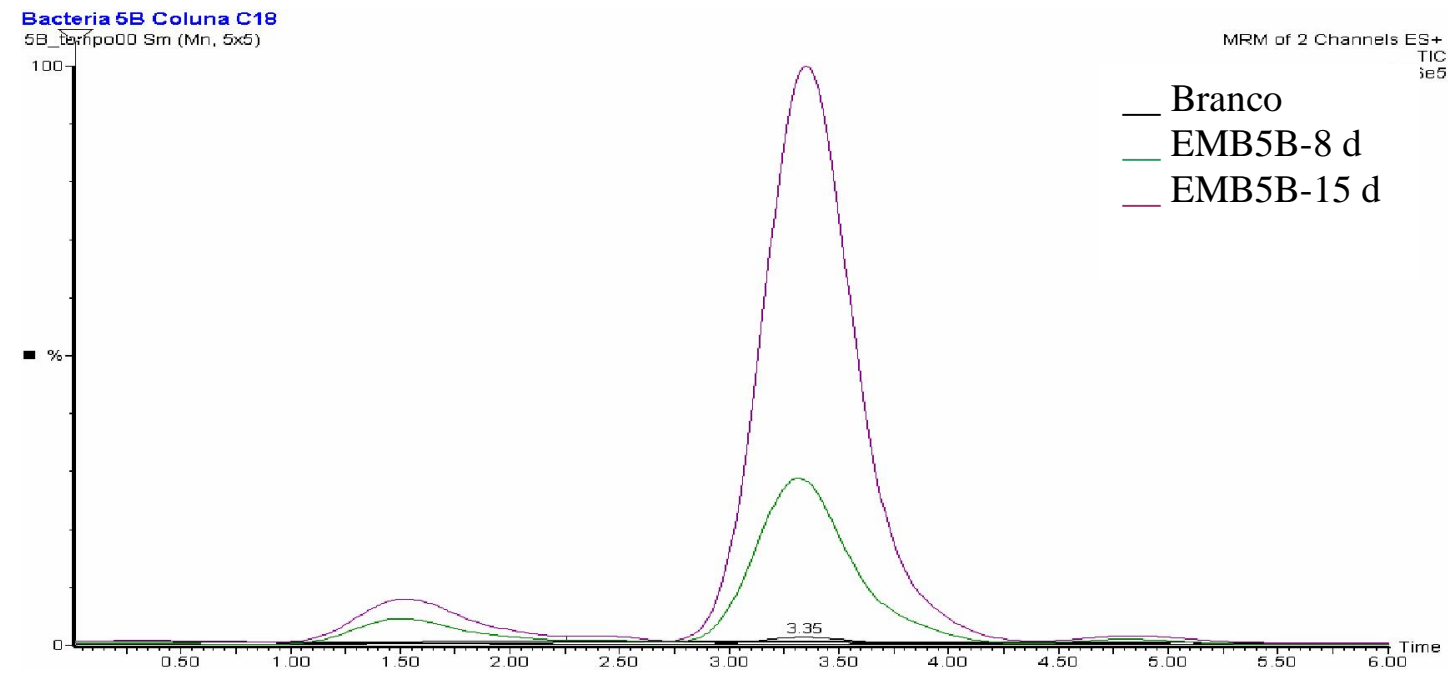

Figura 42. Cromatograma de LC-MS/MS (modo MRM), canal $\mathrm{m} / \mathrm{z} 431>155$, para a fermentação da bactéria EMB5B para o branco 8, 15 dias (meio BD). 
Os dados do experimento foram analisados através de uma curva construída a partir das áreas dos cromatogramas obtidos para os canais selecionados em função do período de fermentação (Figura 43).

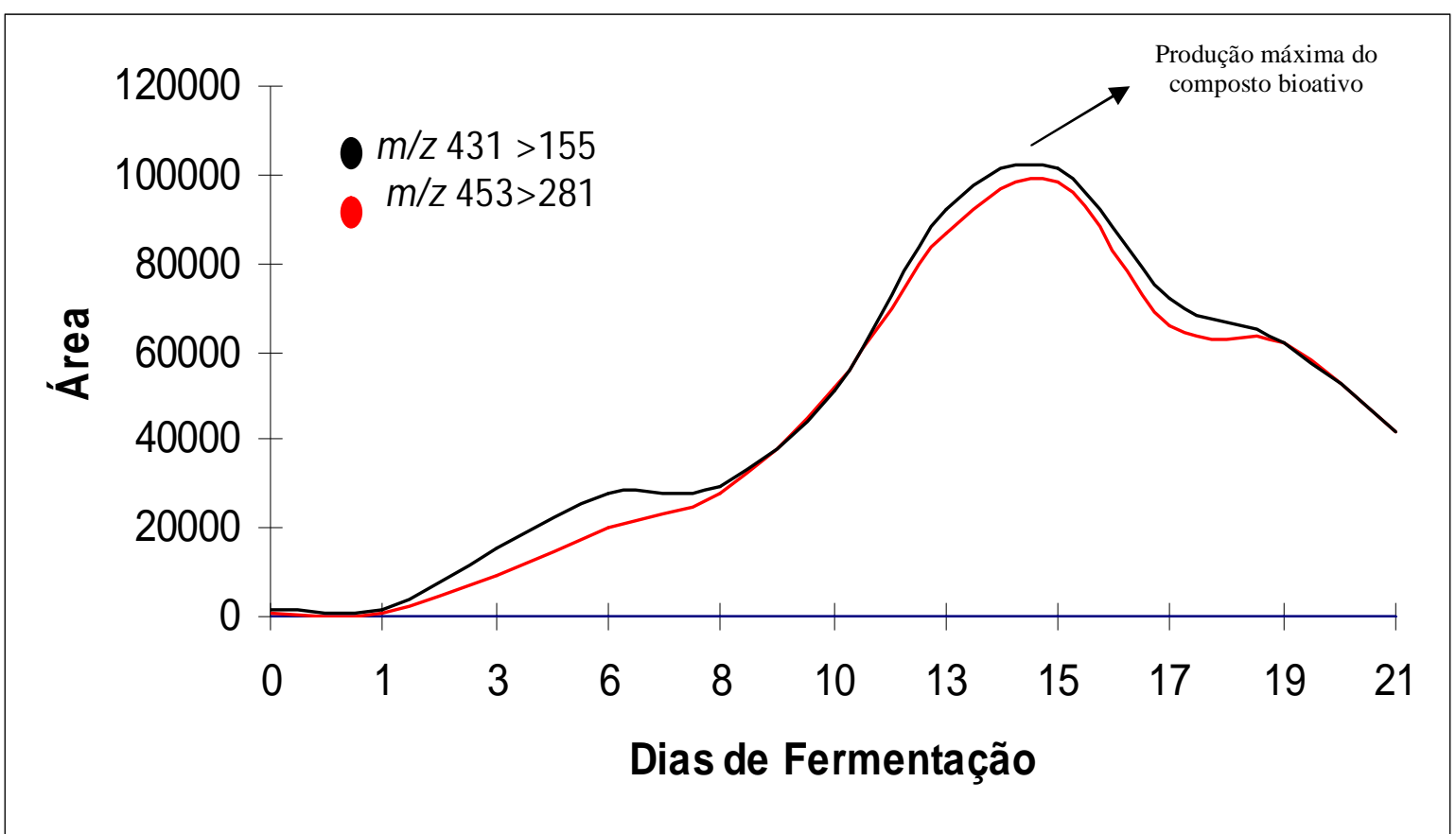

Figura 43. Monitoramento da produção do composto bioativo na fermentação da bactéria EMB5B em meio $\mathrm{BD}$ a $28^{\circ} \mathrm{C}$.

Podemos observar no gráfico, a curva em preto é referente ao monitoramento do composto ativo protonado (canal m/z 431 >155) e a uma curva em vermelho é referente ao monitoramento do composto ativo sodiado ( $\mathrm{m} / \mathrm{z} 453>281$ ). O gráfico mostra que, em relação ao composto ativo a produção pela bactéria foi crescente do a partir do $1^{\circ}$ dia até atingir seu máximo, aproximadamente no $1^{\circ}$ dia. A partir do 15으 dia, observa-se que o composto está sendo "consumido" uma vez que a curva sofre um declínio até o $21^{\circ}$ dia de análise, ultimo dia de analise. 
Através da análise desses dados foi possível definir com precisão o período ótimo de produção do metabólito bioativo pela bactéria EMB5B em aproximadamente 15 dias de fermentação. Este dado está em concordância com os resultados prévios obtidos para os bioensaios de fitotoxicidade, onde a atividade máxima do extrato foi observada entre o intervalo de 11 e 17 dias.

\section{7 - Influência do meio de fermentação}

Além do tempo de fermentação, a composição do meio de cultura também pode afetar a produção de metabólitos secundários pelos microrganismos. Desta forma, a influência do meio na produção do composto ativo também foi avaliada.

A biossíntese de metabólitos secundários freqüentemente está relacionada a algum tipo de carência nutricional e ocorre na ediofase do crescimento microbiano. Estas substâncias são derivadas de diferentes intermediários do metabolismo primário tem como precursores principais aminoácidos, ácidos chiquímicos, acetilCoA, ácido mevalônicos, polissacarídeos e peptídeossacarídeos. Muitos substratos de carbono ou nitrogênio que são rapidamente metabolizados e, conseqüentemente, promovem um crescimento celular máximo, podem inibir a produção de metabólitos secundários. ${ }^{80}$ Em estudo realizado com Streptomyces scabies, Beaulieu e colaboradores ${ }^{81}$ mostraram que os aminoácidos triptofano e a fenilalanina quando presentes nos meios de cultura desse microrganismo são inibidores da produção da fitotoxina taxtomina $A$, enquanto que diversos 
aminoácidos alifáticos não causam declínio significativo na produção da substância e modificações estruturais no triptofano promovem a síntese da toxina.

Neste estudo, a bactéria EMB5B foi fermentada em quatro diferentes meios de cultura: os meios líquidos BD, TSB, quínoa e aveia. Cada meio foi preparado em duplicata em Erlenmeyers de $250 \mathrm{ml}$, contendo em cada um $50 \mathrm{ml}$ de meio.

Os extratos orgânicos dessas fermentações foram analisados por HPLC. Os quatro meios (BD, quínoa, TSB e aveia) foram submetidos a essas condições cromatográficas. Os experimentos foram realizados usando coluna CN (4.60 x 250 mm), Phenomenex; a fase móvel foi composta por uma mistura de $\mathrm{H}_{2} \mathrm{O}$ / ACN $10 \%$ e acetato de amônio $10 \mathrm{mM}$. A eluição foi isocrática e o fluxo foi de $1 \mathrm{ml} / \mathrm{min}$. Os compostos foram visual izados no comprimento de onda $254 \mathrm{~nm}$.

O estudo inicial do perfil químico dos extratos em diferentes meios foi feito por LC-UV. Os cromatogramas desses extratos e cromatograma referente a fração 1 são verificados na Figura 44. 

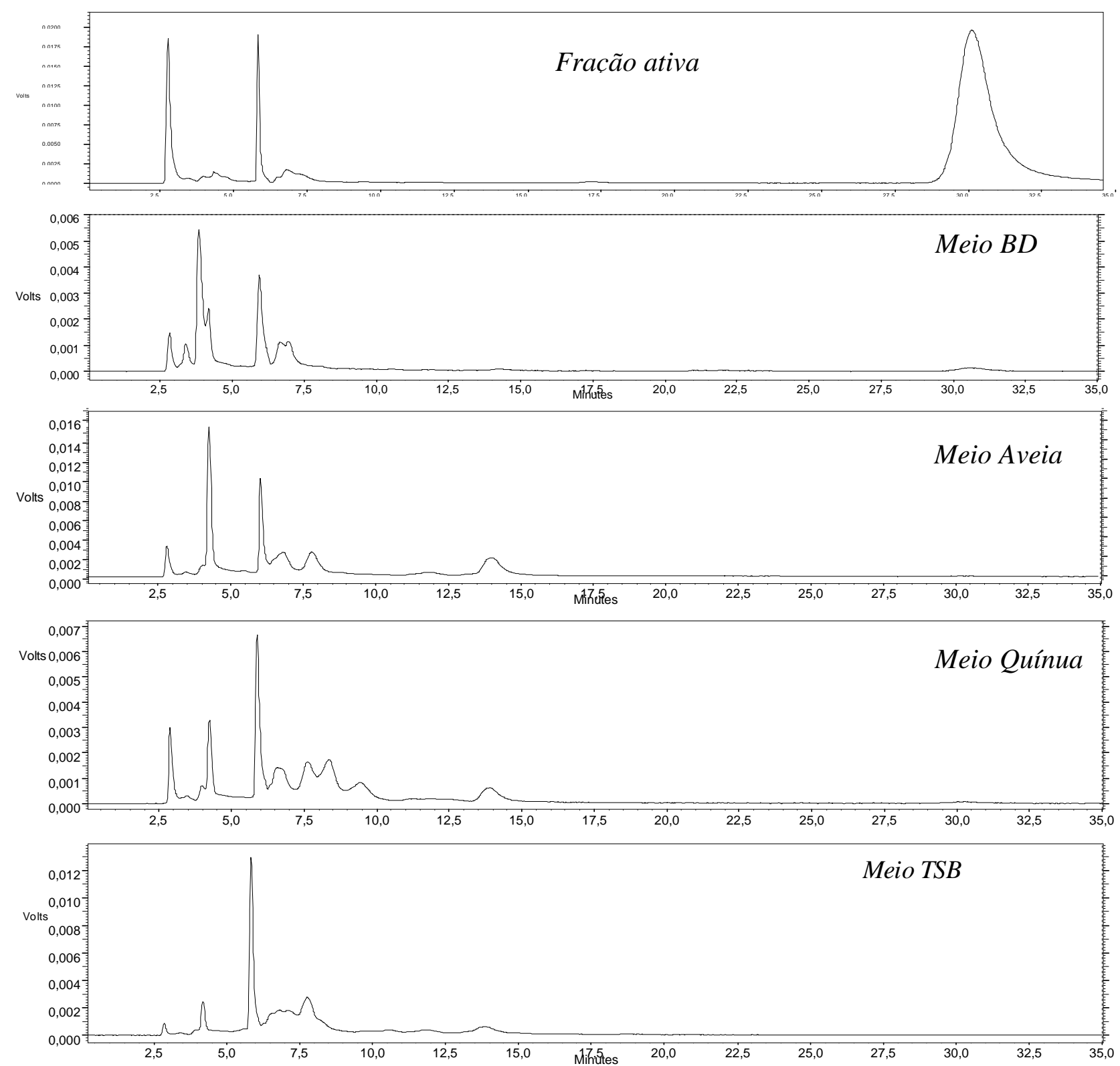

Figura 44. Cromatogramas de LC-UV da fração ativa e dos extratos EMB5B obtidos em meios BD, aveia, TSB e quínua. Fase móvel: $\mathrm{H}_{2} \mathrm{O} / \mathrm{ACN10} \%$ e acetato de amônio $10 \mathrm{mM}$, coluna CN (4.60 x $\left.250 \mathrm{~mm}\right)$, fluxo $1 \mathrm{ml} / \mathrm{min}$ e $254 \mathrm{~nm}$. 
Podemos observar pelo cromatograma do composto bioativo (Figura 44) um pico em $t_{R}$ de 30 minutos. A partir desse cromatograma é possível identificar o pico referente ao composto ativo, em todos os extratos. Podemos verificar que somente no meio BD, ocorreu a produção do composto ativo. Para os outros meios não foi constatada a formação da fitotoxina com $t_{R} 30$ min.

\section{8 - Considerações gerais sobre os PHBs}

Polihidroxialcanoatos (PHAs) são materiais de reserva intracelulares que são acumulados por vários microrganismos geralmente sobre condições nutricionais desfavoráveis como baixa demanda de nitrogênio, fósforo, oxigênio, magnésio ou potássio e na presença de excesso de fonte de carbono.82

PHB é acumulado nas células como grânulos distintos protegidos por membranas. Esses compostos desempenham importantes funções. Além de serem matérias de reserva de energia das células, os PHBs também atuam como fonte de energia no processo de fixação simbiótica de nitrogênio por bactérias do gênero Rhizobium e Bradyrhizobium. 83 Também são encontrados nas células participando da regulação da concentração de cál cio e na sinal ização desse íon. ${ }^{73}$ Porém, a aplicação mais importante dos PHBs é como biopolímeros, utilizados atualmente, para substituir compostos derivados de petróleo.

Os PHBs são poliésteres bacterianos, que possuem as propriedades mecânicas semelhantes a do polipropileno e, por isso, têm sido empregados como 
termoplásticos biodegradáveis para uma grande variedade de aplicações, uma vez que são degradados por enzimas ou por hidrólise. ${ }^{74}$ U ma vez que esses materiais são produzidos por fontes renováveis e decompostos no ambiente, eles são menos danosos ao ambiente em relação aos materiais plásticos produzidos a partir do petróleo.

Recentemente, várias espécies de bactérias, como A Ical igenes eutrophus, Bacillus megaterium, Pseudomonas oleovorans, Rhodospirillum rubrum mostraram potencial na produção de PHBs.

De acordo com o número de átomos de carbono constituindo as unidades monoméricas os PHAs bacterianos podem ser classificados em 2 grupos: os PHA de cadeia curta com cinco ou menos átomos de carbono (SHL) e os PHAs de cadeia média com seis ou mais átomos de carbono (MCL).84

\section{9 - Desreplicação do extrato bruto da EMB5B}

Também foram identificados nos extrato brutos EMB5B, outros polihidroxibutiratos de baixo peso molecular, porém contendo cadeias abertas. Os espectros de massas apresentaram picos moleculares relativas às moléculas protonadas bem como os respectivos adutos sodiados. Foram identificados os compostos contendo de 3 até 6 unidades monoméricas, como mostra a Figura 45. 


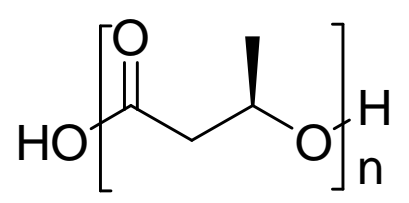

Os seguintes PHBs de cadeia aberta foram identificados:

- Trímero ( $n=3)$, o qual apresentou os íons moleculares de $\mathrm{C}_{12} \mathrm{H}_{22} \mathrm{O}_{8} \mathrm{~m} / \mathrm{z}$ 277,129 [M +H ]+ em/z 299,111 [M + N a]+referente ao

- Tetrâmero ( $n=4), \mathrm{C}_{16} \mathrm{H}_{28} \mathrm{O}_{10}$ o qual apresentou os íons moleculares de $\mathrm{m} / \mathrm{z}$ $363,165[\mathrm{M}+\mathrm{H}]^{+}$e $\mathrm{m} / \mathrm{z} 385,148[\mathrm{M}+\mathrm{Na}]^{+}$.

-Pentâmero $(n=5), \mathrm{C}_{20} \mathrm{H}_{32} \mathrm{O}_{11}$ o qual apresentou os íons moleculares de $\mathrm{m} / \mathrm{z}$ $[\mathrm{M}+\mathrm{H}]+449,202 \mathrm{e} \mathrm{m} / \mathrm{z}+471,184[\mathrm{M}+\mathrm{Na}]$.

-Hexâmero ( $n=6), \mathrm{C}_{24} \mathrm{H}_{40} \mathrm{O}_{14}$ O qual apresentou os íons moleculares de $\mathrm{m} / \mathrm{z}$ $535,239[\mathrm{M}+\mathrm{H}]^{+}$e m/z 557,221 [M+Na]+.

Este resultado comprova a imensa contribuição da espectrometria de massas com fonte electrospray para a química de produtos naturais em especial na desreplicação de extratos brutos. 
Amostra Tania- Bact'eria 5B- 5 dias

TANIA_5B-5D 17 (0,881) Cm (13:32)

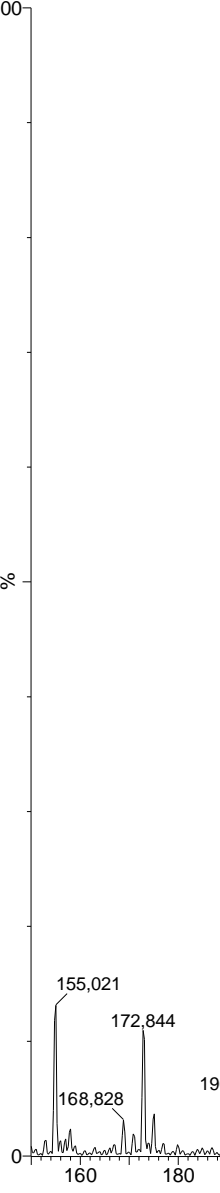

Figura 45. Espectros de massas ESI ${ }^{+}$dos extratos orgânicos de EMB5B-5dias. Potencial do cone 55eV. 


\subsection{0 - Síntese do composto fitotóxico}

A síntese do pentólido foi realizada a partir do ácido (R)-3hidroxibutírico e do ácido (S)-3-hidroxibutírico seguindo procedimento descrito por Seebach.$^{85}$ Nesta etapa o principal objetivo foi o de avaliar a atividade fitotóxica do composto em relação aos diferentes oligômeros formados e sua configuração.

Os microrganismos são altamente estereoseletivos. Especificamente na via metabólica das bactérias para a produção de PHB, enzima PHA sintetase, envolvida na conversão de ácido graxo a polihidroxibutirato é ativa somente para os isômeros R. ${ }^{86}$

A Figura 46 apresenta o espectro de massas ESI-MS no modo positivo do bruto da reação por inserção direta via bomba de seringa. São observados os de sinais de $\mathrm{m} / \mathrm{z}(\mathrm{M}+\mathrm{H})+259,345,431,517,603,689,775$ e 861 . A diferença de massa observada para esses sinais é de $86 \mathrm{Da}$. Esses sinais foram atribuídos aos macrociclos com n=3; 4; 5; 6; 7; 8; 9 e 10 unidades monoméricas. 


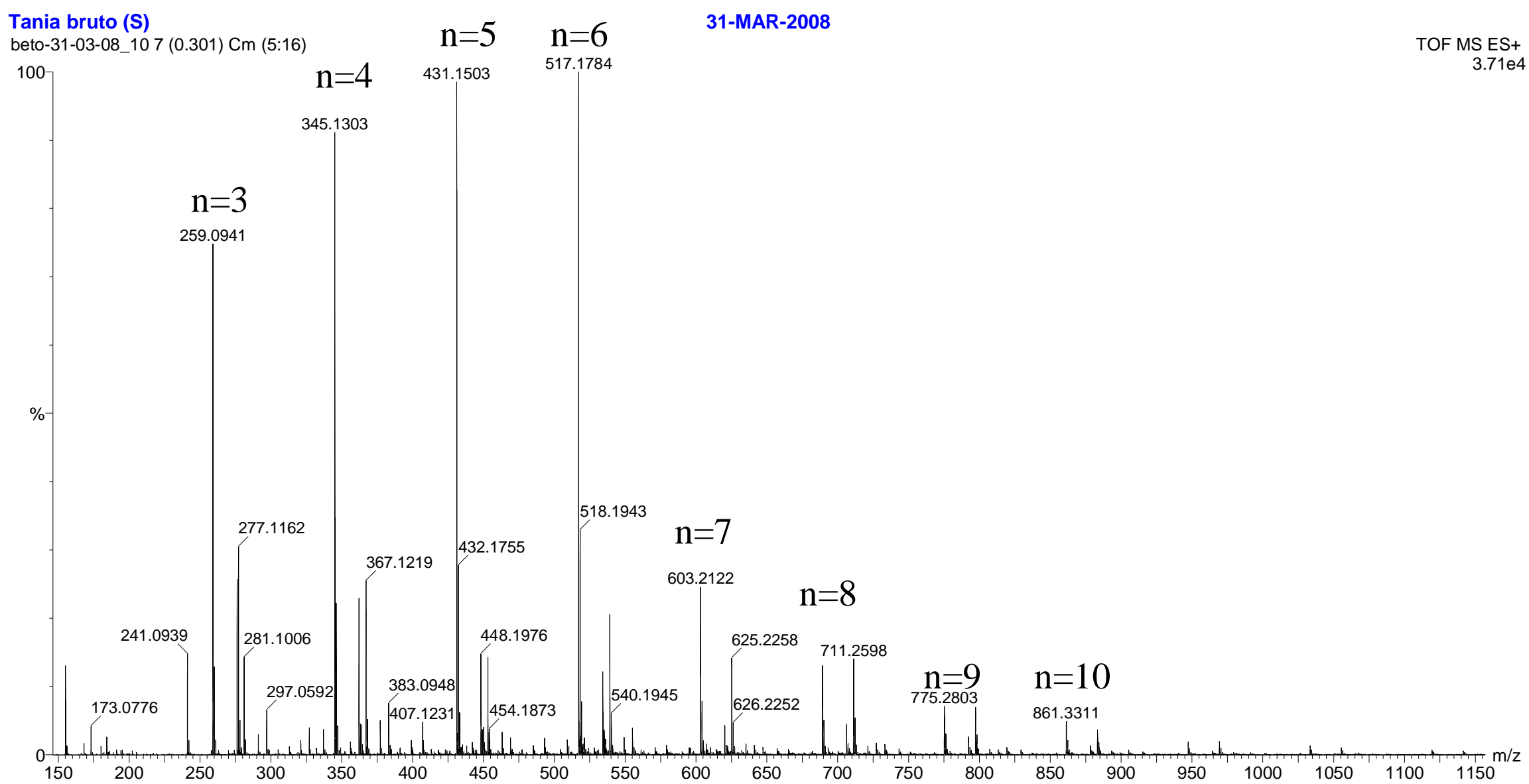

Figura 46. Espectro de massas ESI+ do bruto reacional da síntese do pentólido. 
O bruto reacional também foi analisado por $\mathrm{RMN}^{13} \mathrm{C}$. Seebach e colaboradores, 85 caracterizaram aos compostos cíclicos formados com base nos deslocamentos químicos característicos das carbonilas de cada um deles. Cada macrólido possui um deslocamento químico único e característico para cada átomo de carbono carbonílico, com o triólido em campo mais baixos e o decólido em campos mais altos. Seguindo esta metodologia os macrociclos formados foram identificados contendo 3, 4, 5, 6 e 7 unidades monoméricas, apresentando deslocamentos químicos de $\delta 170.3 ; \delta$ 169,9; $\delta$ 169,6; $\delta$ 169,5; $\delta$ 169,4, respectivamente (Figura 47). 


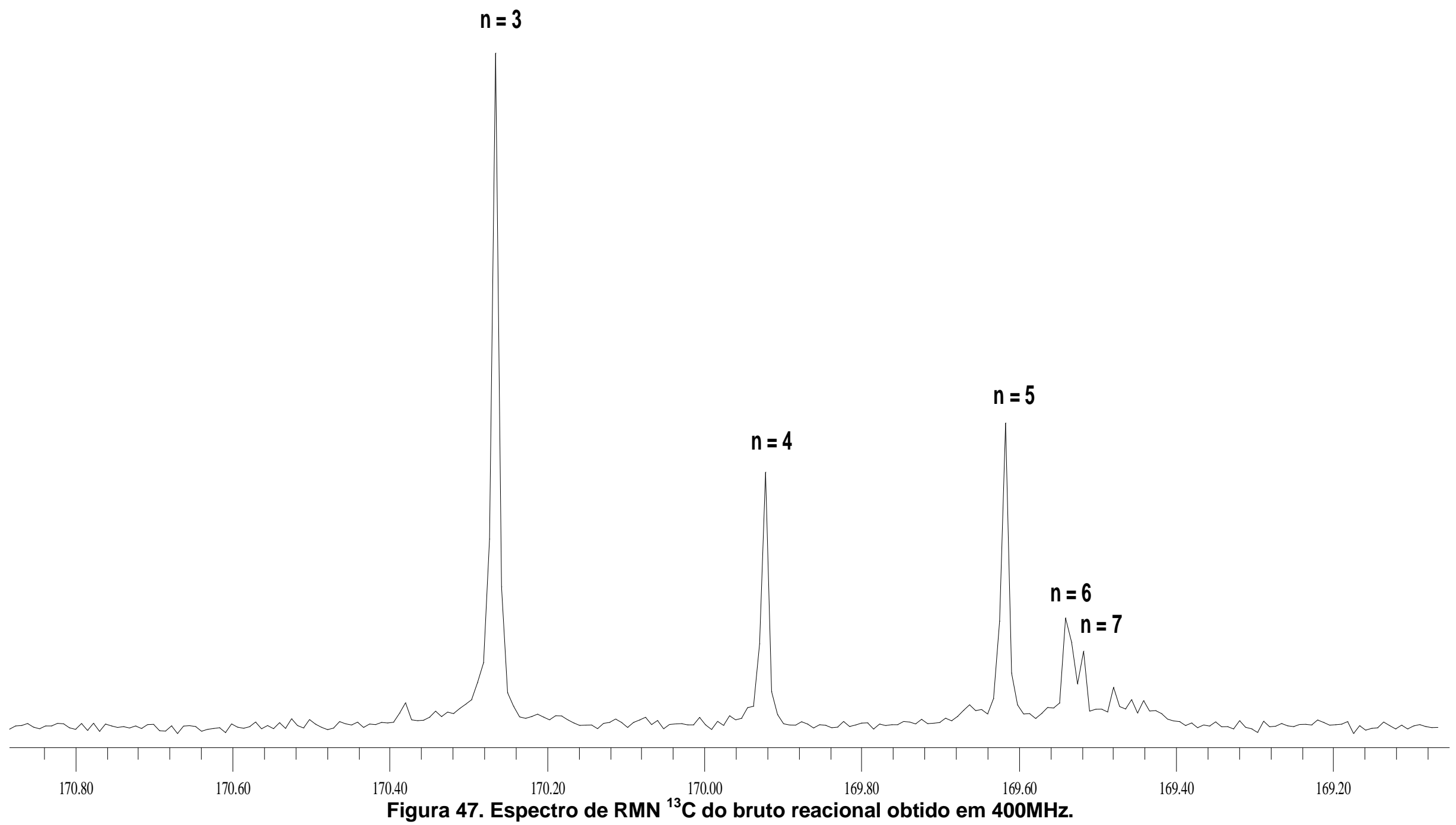


Comparando o resultado das análises do bruto reacional obtidos por ESI-MSe por RMN é observada uma diferença entre a quantidade de compostos que foram detectados, em cada uma dessas técnicas. Em relação ao espectro de massas foi possível identificar os ciclos contendo de 3 a 10 unidades de 3-(R)-hidroxibutirato. Já no espectro de RMN identificaram-se cinco oligômeros principais, os quais, são formados por 3, 4, 5, 6 e 7 unidades monoméricas.

Isso ocorre porque os anéis maiores podem não ser produtos da síntese da reação. Eles podem ser formados a partir dos oligômeros menores, especialmente na presença de traços de ácido ou base. ${ }^{6}$ Como esse composto é facilmente ionizado, este pode ser detectado por ESI-MS mesmo quando presentes traços desses na amostra. No caso da espectroscopia de RMN, é uma técnica que depende da quantidade de amostra e é menos sensível do que a espectrometria de massas. Conseqüentemente, os compostos presentes em concentrações muito baixas não foram detectados, nessas condições de análise. Pela integração dos sinais é possível determinar os compostos que preval eceram na síntese.

Os brutos reacionais, tanto para o ácido (R)-3-hidroxibutírico quanto para o ácido (S)-3-hidroxibutírico, foram submetidos à bioensaios de fitotoxicidade com Lemna minor e nenhum deles apresentou atividade. Este resultado pode estar relacionado ao fato da concentração do pentólido ser relativamente baixa na mistura reacional. 

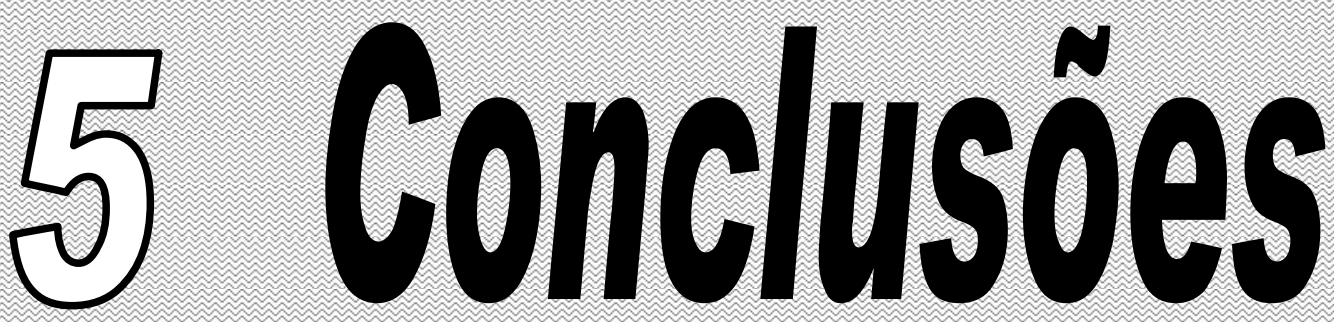

Podemos concluir que a metodologia empregada nesse trabalho para a identificação e isolamento de fitotoxinas foi desenvolvida com sucesso. O emprego da espectrometria de massas, em especial o ESI, em conjunto com bioensaio de fitotoxicidade com Lemna minor possibilitou a identificação de uma fitotoxina de uma maneira rápida e eficiente.

Além disso, a espectrometria de massas mostrou ser uma ferramenta eficiente para ser aplicada no monitoramento e otimização de processos fermentativos, devido a sua al ta sensibilidade e sel etividade, para o composto de interesse pelo emprego do modo de varredura MRM. Mesmo sem a caracterização estrutural do princípio ativo, foi possível monitorar a produção do analito, uma vez que era conhecida sua massa molecular ea massa do respectivo fragmento mais abundante.

O composto ativo identificado, um ciclopentólido da família dos PHBs, já foi previamente sintetizado, porém nunca foi isolado de fontes naturais, e é a primeira vez que sua atividade fitotóxica é relatada. Uma característica relevante desse composto é a capacidade de formar complexos com metais. 
Em vista da atividade fitotóxica do pentólido e de suas características estruturais, acreditamos que o trabalho desenvolvido possa servir como modelo para a síntese de novas classes de herbicidas. 


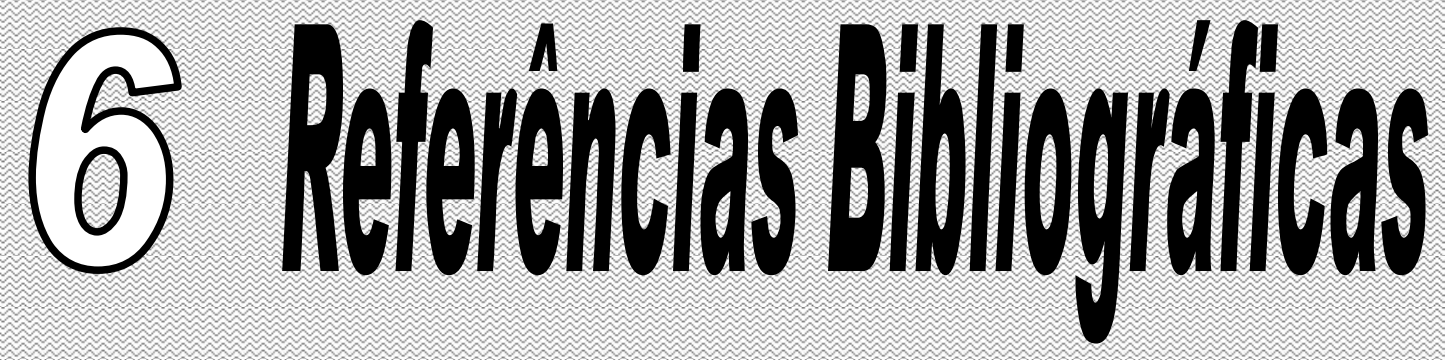

1. ROESSNER, C. A.; AI, S.; "Genetically engineered synthesis of natural products: from alkaloids to corrins" - Annual Review of Microbiology; 50: 467-490, 1996.

2. NEWMAN, D. J.; CRAGG, G. M.; "Natural Products as Sources of New Drugs over the Last 25 Years" - Journal of Natural Products; 66:1022-1037, 2003.

3. DEMAIN, A. L.; "Pharmaceutically active secondary metabolites of microorganisms" - Applied Microbiology and Biotechnology; 52: 455-463, 1999.

4. SAXENA, S.; PANDEY, K. A.; "Microbial metabolites as eco-friendly agrochemicals for the next millennium" - Applied Microbiology and Biotechnology; 55:395 - 403. 2001.

5. VINNING, L.C.; "Functions of secondary metabolites" - Annual Review of Microbiology; 44:395-427, 1990.

6. DREW, S. W.; "Effect of primary metabolites on secondary metabolism" - Annual Review of Microbiology; 31: 343-56,1977.

7. SANCHES, S.; DEMAIN, A. L.; "Metabolic regulation of fermentation processes" - Enzyme and Microbial Technology; 31:895-906, 2002.

8. LI, Y.; SUN, Z.; ZHUANG, X.; XU, L.; CHEN, S; Li, M; "Research progress on microbial herbicides" Crop Protection; 22: 247-252, 2003.

9. MCFADYEN, R.E.C.; "Biological control of weeds"; Annual review of entomology; 43:369-93; 1998.

10. VYVYAN, J. R.; "Allelochemicals as leads of new herbicides and agrochemicals" - Tetrahedron; 58:1631-1646, 2002.

11. MELO, I. S.; AZEVEDO, J. L.; In: Controle Biológico, Embrapa: p. 1- 121, 2000.

12. BASILEA, A.; SORBOA, U. S.; GIORDANOA, S.; RICCIARDIB, L.; FERRARAA, S.; MONTESANOC, D.; CASTALDO,R.; COBIANCHA; VUOTTO; C. M. L.; FERRARAC, L.; "Antibacterial and allelopathic activity of extract from Castanea sativa leaves"- Fitoterapia; 71:110116, 2000.

13. MACIAS, F. A.; VARELA, R. M.; TORRES, A. M.; OLIVA, R. M.; MOLINILLO, J. M. G.; "Bioactive norsesquiterpenes from Helianthus annus with potential allelopathic activity" - Phytochemistry; 48: 631-636,1998.

14. LANGE, L., LOPEZ, C. S. Microorganisms as a source of biologically active secondary metabolites. In: COPPING, L. G. Crop protection agents from nature. Cambridge: p. 1-20, 1996. 
15. DUKE,S. O.; DAYAN, F. E.; ROMAGNI, J. G; RIMANDO, A. M.; "Natural products as sources of herbicides: current status and future trends" - Weed Research; 40:99-111;2000.

16. STRANGE, R. N.; "Phytotoxins produced by microbial plant pathogens" - Natural Products Reports; 24:127-144, 2007.

17. STEWARD, W. W.; "Isolation and proof of structure of wildfire toxin."- Nature; 229:174-178,1971.

18. GREAVES, M. P.; Microbial herbicides: Factors in development,. In COPPING, L.G. Crop protection agents from nature. Cambridge: p. 444-.467, 1996.

19. DUKE,S. O.; DAYAN, F. E.; ROMAGNI, J. G; RIMANDO, A. M.; "Natural products as sources of herbicides: current status and future trends" - Weed Research; 40:99-111;2000.

20. VANMIDDELSTORTH, F.; CANNELL, R. J. P.; Dereplication and partial identification of natural products. In: CANNELL, R. J. P., Natural Products Isolation. Humana Press: p. 279-327, 1998.

21. GRABLEY, S.; THIERICKE, R.; "The impact of natural products in drug discovery"; Drugs discovery from nature; Ed. Springer, NY, p. 3-37,1999.

22. W.M.A. NIESSEN, J. VAN DER GREEF, Liquid Chromatography-Mass Spectrometry, Principles and Applications, Marcel Dekker, N Y, 1992.

23. HOSTETTMANN, K., DOMON, B., SCHAUFELBERGER, D., HOSTETTMANN, M., J. "Liquid chromatography coupled to mass spectrometry and nuclear magnetic resonance spectroscopy for the screening of plant constituents" - Journal of Chromatography A, 794: 299-316,1998.

24. LEE, M. S.; KERNS, E. H.; "LC/MS applications in drug development" - Mass Spectrometry Reviews, 18:187-279, 1999.

25. NIESSEN, W. M. A; Greef,J.; "Liquid Chromatography-Mass Spectrometry, Principles and Applications", Marcel Dekker, NY, 1992.

26. BITZER, J.; KÖPCKE, B.; STADLER, M.; HELLWIG, V.; JU, Y.; SEIP, S.; HENKEL, T.; "Accelerated Dereplication of Natural Products, Supported by reference libraries"- Natural Products In drug discovery61: 332-338, 2007.

27. HOSTETTMANN, K., WOLFENDER, J.-L., "Liquid chromatography coupled to mass spectrometry and nuclear magnetic resonance spectroscopy for the screening of plant constituents" - Journal of Chromatography A, 794: 299-316, 1998.

28. ZHOU, S., HAMBURGER, M.; "Application of liquid chromatography-atmospheric pressure ionization mass spectrometry in natural product analysis evaluation and optimization of electrospray and heated nebulizer interfaces" - Journal of Chromatography A; 755:189-204,1996.

29. NIESSEN, W.M.A; "Progress in liquid chromatography-mass spectrometry instrumentation and its impact on high-throughput screening" - Journal of Chromatography A; 1000:413-436,2003.

30. NIELSEN, K. F.; SMEDSGAARD J.; "Fungal metabolite screening: database of 474 mycotoxins and fungal metabolites for dereplication by standardised liquid chromatography-UV-mass spectrometry methodology"-Journal of Chromatography A; 1002:111-136, 2003.

31. AYER, S. W.; ISAAC, B. G; LETENDRE, L. J.;STONARD, R. J.; Herbicidal nucleosides from microbial sources- The Journal of the antibiotics; 44: 729-732,1991.

32. LARSEN,T.O.; SMESDGARRD,J.; NIELSEN,K.F.; HANSEN, M.E.;FRISVAD,J. C.;"Phenotypic taxonomy and metabolite profiling in microbial drug discovery" - Natural Products Reports; 22:672 
$-695 ; 2005$.

33. BUSS, A. D.;BUTLER, M. S.; "A new model for utilising chemical diversity from natural sources" Drug Development Research, 62:362-370, 2004.

34. WOLFENDER, J. L.; NDJOKO, K.; HOSTETTMANN, K.; "Liquid chromatography with ultraviolet absorbance-mass spectrometric detection and with nuclear magnetic resonance spectroscopy: a powerful combination for the on-line structural investigation of plant metabolites" - Journal of Chromatography A; 1000:437-455, 2003.

35. STONARD, R. J.; WIDEMAN.M.A.;Herbicides and Plant Growth Regulators, In:GODFREY,C. R. Agrochemicals from natural products, Dekker: p. 285-311, 1994.

36. DUKE, S. O.; DAYAN, F. E.; ROMAGNI, J. G.; "Investigating the mode of action of natural phytotoxins" - Journal of Chemical Ecology, 26:2079-2094, 2000.

37. ROST, T. L.; HESS, F. D.; Analysis of the mitotic index in root tip meristems as a tool to determine herbicide cell cycle specificity; In: BOGER, P.; Target assays for modern herbicides and related phytotoxic compounds. Lewis Publishersp: p.185-287, 1992.

38. FAIRCHILD, J.F.;RUESSLER, D.S.; HARVERLAND, P.S.; CERLSON, A.R.; "Comparative Sensitivity of Selenastrum capricornutum and Lemna minor to Sixteen Herbicides Archives of Environmental Contamination and Toxicology"; 32:353-357,1997.

39. RAHMAN, A.; CHOUDHARY, M., I.; THOMSEN, W.J.; in "Bioassay Techniques for Drug Development"; Hardwood academic publishers,p. 109-113, 2001.

40. WANG, W.; "Literature Review on Duckweed Toxicity Testing"- Environmental Research; 52:7-22, 1990.

41. HULSEN, K; MINNE, V.; LOOTENS, P.; VANDECASTEELE, P; HOFTE, M.; "A chlorophyll a fluorescence-based Lemna minor bioassay to monitor microbial degradation of nanomolar to micromolar concentrations of linuron" - Environmental Microbiology; 4:327-337,2002.

42. PUYVELDE, L. V.; BOSSELAERS, J. C.; STEVENS, C.; KIMPE, N. D.; GESTEL, J. V.; DAMME, P. V.; "Phytotoxins from the Leaves of Laggera decurrens" - Journal of Agricultural and Food Chemestry 47: 1116 - 1119, 1999.

43. BUSSE, H, J., DENNER, E. B. M.; LUBITZ, W; "Classification and identification of bacteria: current approaches to an old problem. Overview of methods used in bacterial systematic" - Journal of Biotechnology; 47: 3- 38, 1996.

44. American Society for Testing and Materials (1993) "Standard Guide for conducting toxicity tests with Lemna Gibba" .In: Annual book of ASTM standards: American Society for Testing and Materials, Philasdephia,PA, p. 1232.

45. SHIMABUKURO, R. H.; SWANSON, H. R.; "Atrazine Metabolism, Selectivity, and Mode of Action" - Journal of Agricultural and Food Chemistry; 17: 199-205, 1969.

46. SARMA, B.K.; SINGH, U.P.; "Ferulic acid may prevent infection of Cicer arietinum by Sclerotium rolfsii" - World Journal of Microbiology \& Biotechnology; 19:123-127, 2003.

47. STACKEBRANDT, E.; GOEBEL, B.M. "Taxonomic note: a place for DNA-DNA reassociation and 16S rDNA sequence analysis in the present species definition in bacteriology."- International Journal of Systematic and Bacteriology, 44:846-849, 1994.

48. MCLOUGHLIN, T. J., QUINN, J. P., BETTERMANN, A.,BOOKLAND, R.; "Pseudomonas cepacia suppression of sunflower wilt fungus and role of antifungal compounds in controlling the disease." 
- Applied and Environmental Microbiology; 58:1760-1763, 1992.

49. HEBBAR, P.K., MERTEL, M.H.; HEULIN, T.; "Suppression of pre- and postemergence dampingoff in corn by Burkholderia cepacia." - European journal of plant pathology; 104: 29-36, 1998.

50. VAN, V. T.; BERGE, O.; NGO KE, S., BALANDREAU, J., HEULIN, T. "Repeated beneficial effects of rice inoculation with a strain of Burkholderia vietnamiensis on early and late yield components in low fertility sulphate acid soils of Vietnam“ - Plant and Soil; 218: 273-284, 2000.

51. PARKE, J.L.; RAND, R.E.; JOY, A.E.; KING, E.B.; Biological control of Pythium damping-off and Aphanomyces root rot of peas by application of Pseudomonas cepacia or $P$. fluorescens to seed. Plant Disease 75:987-992, 1991.

52. BOWERS, J.; PARKE, J.; "Epidemiology of Pythium damping-off and Aphanomyces root rot of peas after seed treatment with bacterial agents for biological control." - Phytopathology; 83:1466$1473,1993$.

53. PARTIDA-MARTINEZ, L. P.; HERTWERCK, C.; "Pathogenic fungus harbours endosymbiotic bacteria for toxin production" - Nature; 437:884-888, 2005.

54. KIRSCHERLACH, K.; PARTIDA-MARTINEZ, L. P.; DAHSE, H. M.; HERTWECK, C.; "Antimitotic Rhizoxin Derivatives from a Cultured Bacterial Endosymbiont of the Rice Pathogenic Fungus Rhizopus Microspores" - Journal of the American Chemical. Society; 128:11529-11536, 2006.

55. DUKE, S. O.; DAYAN, F. E.; ROMAGNI, J. G.; "Investigating the mode of action of natural phytotoxins" - Journal of Chemical Ecology, 26:2079-2094, 2000.

56. PIEL, N. J.; "Metabolites from symbiotic bacteria"- Natural Products reports; 21:519-538, 2004.

57. YUHASHI, K.; ICHIKAWA, N.; EZURA, H.; AKAO, S.; MINAKAWA,Y.; NUKUI, N.; YASUTA, T.; MINAMISAWA, K.; "Rhizobitoxine Production by Bradyrhizobium elkanii Enhances Nodulation and Competitiveness on Macroptilium atropurpureum" - Applied and environmental microbiology, 66: 2658-2663, 2000.

58. SMEDSGARD, J.; FRISVAD, J.C.; "Using direct mass spectrometry in taxonomy and secondary metabolite profiling of crude fungal extracts" - Journal of Microbiological Methods; 25, 5-17, 1996.

59. JULIAN, R. K.; Jr., R. E. HIGGS, R. E.; GYGI, J. D.;HILTON, M. D.,"A Method for quantitatively differentiating crude natural extracts using high-performance liquid chromatography - electrospray mass spectrometry" - Analytical Chemistry; 70: 3249-3254,1998.

60. HIGGS, R.; ZAHN, J. A.; GYGI, J. D.; HILTON, M. D.; "Rapid method to estimate the presence of secondary metabolites in microbial extracts" - Applied and environmental microbiology; 67: 371376, 2001.

61. CROTTI, A. E. M.; VESSECCHI, R.; LOPES, J. L. C.; LOPES, N. P.; "Espectrometria de massas com ionização por "electrospray": processos químicos envolvidos na formação de íons de substancias orgânicas de baixo peso molecular" - Química Nova, 29: 287-292, 2006.

62. PAVIA, L.D.; LAPMAN,G. M.; In: Introduction to Spectroscopy, Harcourt Brace \& Company, NY, 1996.

63. BARROS, F. F. C.; QUADROS, C. P. P.; JÚNIOR, M. R. M.; PASTORE, G. M.; "Surfactina: Propriedades químicas, tecnológicas e funcionais para aplicações em alimentos" - Química Nova, 30:409-414, 2007.

64. KOWALL, M.; VATER, J.; KLUGE, B.; STEIN, T.; FRANKE, P.; ZIESSOW, D.; "Separation and characterization of surfactin of isoforms produced by Bacillus subtilis OKB 105" - Journal of 
Colloid and Interface Science, 204, 1-8, 1998.

65. INANAGA, J.; HIRATA, K.; SAEKI, H.; TSUTOMU, K.; YAMAGUSHI, M.;"A rapid esterefication by means of mixed anhydride and its application to large ring lactonization"- Bulletin of the chemical society of Japan; 52: 1989-1993, 1979.

66. SEEBACH, D.; BRANDLI, U.; SCHNURRENBERGER, P.; "High-Yield synthesis of 20-, 24- and 28-memberd macropentolide, -hexolide and -heptolode, respectively, from (R) - or (S) - 3hydroxybutanoic acid under Yamaguchi's macrolization conditions." Helvetica Chimica Acta,71: 155-167, 1988.

67. DOI, Y; KAWAGUCHI, Y.;NAKAMURA, Y.; KUNIOKA, M. "Nuclear Magnetic Resonance Studies of Poly(3-Hydroxybutyrate) and Polyphosphate Metabolism in Alcaligenes eutrophus" - Applied and environmental microbiology;55: 2932-2938, 1989.

68. HAHN, S. K.; CHANG, Y. K.; LEE, S. Y.; "Recovery and Characterization of Poly (3-Hydroxybutyric Acid) Synthesized in Alcaligenes eutrophus and Recombinant Escherichia coli" - Applied and environmental microbiology; 61: 34-39; 1995.

69. MISRA, A. K;. THARKUR, M. S; SRINIVAS, P.; KARANTH, N. G.; "Screening of poly-_hydroxybutyrate-producing microorganisms using Fourier transform infrared spectroscopy"Biotechnology Letters; 22:1217-1219, 2000.

70. DUKE, S.O.;"Overview of Herbicide Mechanisms of Action" - Environmental Health Perspectives. 87:263-271,1990.

71. DAYAN, F. E.; ROMAGNI, J. G.; DUKE, S. O.; "Investigating the mode of action of natural phytotoxins"- Journal of Chemical Ecology, 26: 2079-2094, 2000.

72. LIN, W. O.; NETO, J. T. X. B.; "Agentes complexantes: podante, coronante e criptante, classificação e nomenclatura" - Química Nova; 21: 630-634, 1998.

73. SEEBACH, D.; BÜRGER, H. M.; "Cátion transport across bulk liquid organic membranes with oligomers of (R)-3-hydroxybutanoic acid", Helvetica Chimica Acta; 76: 94-97, 1993.

74. ANDERSON, A. J.; DAWES, E. A.; "Occurrece, metabolism, metabolic role and industrial uses of bacterial polyhydroxyalcanoates"- Microbiological Rewies; 54:450-472,1990.

75. PRESSMAN, B. C.; "Biological applications of ionophores"- Annual Review of Biochemistry; 1976.45:501-530.

76. SEEBACH, D.; BRANDLI, U.; MULLER, H. S.; DOBLER, M.; EGLI, M.; "On the Macrolactonization of $\beta$-Hydroxy Acids. Crystal structures of the pentolide and the hexolide from $(R)$-3hydroxybutanoic acid. Molecular modeling studies of the tetrolide.".- Helvetica Chimica Acta; 72:1704 - 1717, 1989.

77. HAMASAKI, T.; FUHII, Y.; FUKUDA, A.;ICHIMOTO, I.; NAKAJIMA, H.; "Tewlve-membered lactones produced by Cladosporium tenuissum and the plant growth retardant activity of Cladosporide B"- Phutochemistry; 40: 1443-1446,1995.

78. PAJON, C. M. G. P.M.; COLLADO, I. G.; "Secondary metabolites isolated from Colletotrichum species" - Natural Product. Reports; 20:426-431, 2003.

79. PEUNTE,P. F.; SÁEZ, M. J. F.; HAMILTON, B.; LEHANE, M.; RAMSTAD, H.; FEREY, A.; JAMES, K. J.; "Rapid determination of polyether marine toxins using liquid chromatography-multiple tandem mass spectrometry" - Journal of Chromatography A; 1056: 77-82, 2004. 
80. GALLO, M.; KATZ, E.; "Regulation of secondary metabolite biosynthesis: catabolite repression of phenoxazinone synthase and actinomycin formation by glucose" - Journal of Bacteriology; 109:659-667, 1972.

81. LAUZIER, A.; GOYER, C; RUEST, L.; BRZEZINSKI, R; CRAWFORD, D. L.;BEAULIEU, C; "Effect of amino acids on thaxtomin A biosynthesis by Streptomyces scabies" - Canadian Journal Microbiology; 48:359-364; 2002.

82. DAWES, E. A., SENIOR, J.P; "The role and regulation of energy reserve polymers in microorganisms." - Advanced Microbial Physiology;10:135-266, 1973.

83. EMERICH, D.W.; KARR, D. B.; WATERS, J. K.; SUZUKI,F.; "Enzymes of the Poly-,bHydroxybutyrate and Citric Acid Cycles of Rhizobium japonicum Bacteroids"- Plant Physiology; 75:1158-1162, 1984.

84. ANNUAR, M. S. M.; TAN, I. K. P.; IBRAIN, S.; RAMACHANDRAN, K. B.; "Production of mediumchain-length poly (3- hydroxyalkanoates) from crude fatty acids mixture by Pseudomonas putida" Food and Bioproducts Processing; 85:104-109, 2007.

85. SEEBACH, D; PlATtNeR, D. A.; BRUNNER, A.; DOBLER, M.; MÜLleR H. M.; PETTER, W; ZBINDEN, P.; "Cyclic oligomers of (R)-3-hydroxybutanoic acid: preparation and structural aspects" - Helvetica Chimica Acta;76:2004-2033, 1993.

86. TAGUCHI, K.; TAGUCHI, .S.; SUDESH, K; MAEHARA, A.; TSUGE, T; DOY, Y.; Metabolic pathways and engineering of PHA biosynthesis. In: DOI, STEINBÜCHEL; Biotechnology of Biopolymers, Wiley-V, p. 161-191, 2005. 